Electronic Supplementary Information (ESI)

\title{
Multi-action Pt(IV) carbamate complexes can co-deliver Pt(II) drugs and amine containing bioactive molecules
}

\author{
Tomer Babu, Amrita Sarkar, Subhendu Karmakar, Claudia Schmidt and Dan Gibson*, ${ }^{\dagger}$ \\ †Institute for Drug Research, School of Pharmacy, The Hebrew University of Jerusalem, \\ Jerusalem-9112102, Israel.
}

*Corresponding author E-mail: dang@ekmd.huji.ac.il 


\section{Contents of Table}

Scheme S1 Synthetic route for the preperation of various cisPt(IV)-carbamato and -carbonato complexes starting from oxoplatin.

Scheme S2 Synthetic scheme for the attachment of PARP inhibitor (3-ABA) to the axial position of $\mathrm{Pt}(\mathrm{IV})$ by carbamate and succinate linker respectively.

Scheme S3 Synthetic scheme for the attachment of HDAC inhibitor $\left(\mathrm{SAHA}-\mathrm{NH}_{2}\right)$ to the axial position of $\mathrm{Pt}(\mathrm{IV})$ by carbamate linkage.

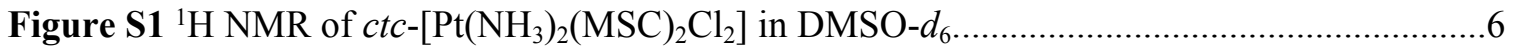

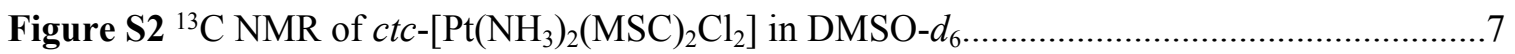

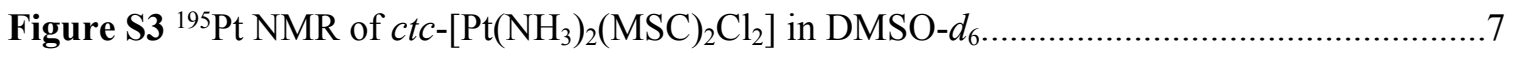

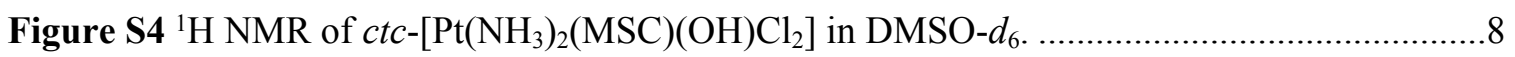

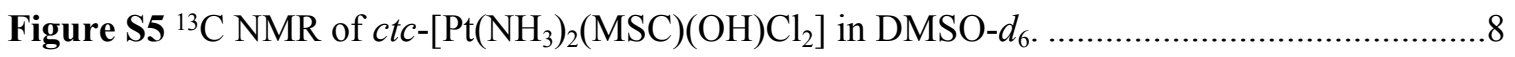

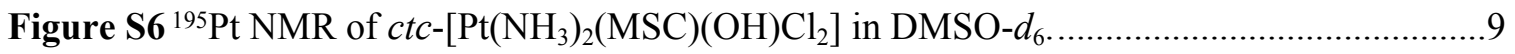

Figure S7 HPLC chromatogram of $c t c-\left[\mathrm{Pt}\left(\mathrm{NH}_{3}\right)_{2}(\mathrm{MSC})(\mathrm{PhB}) \mathrm{Cl}_{2}\right]$ ran in $(0-90 \%)$ acetonitrile gradient in water over $30 \mathrm{~min}$.

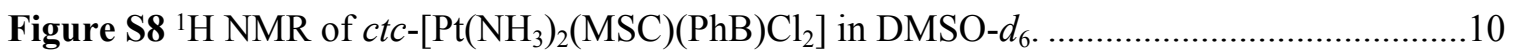

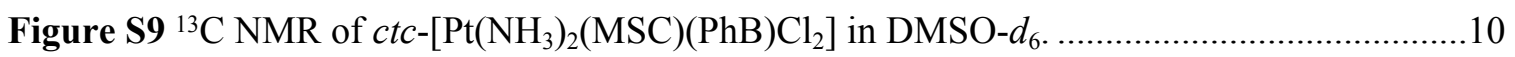

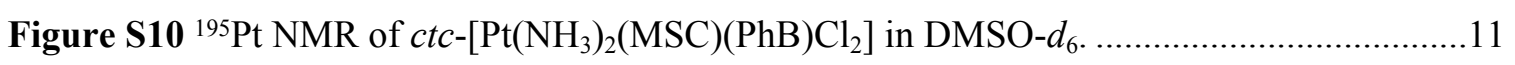

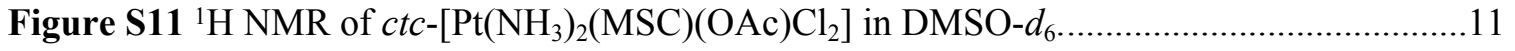

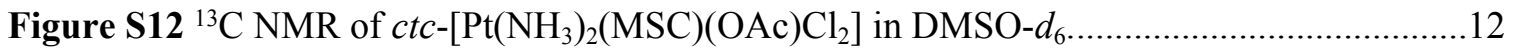

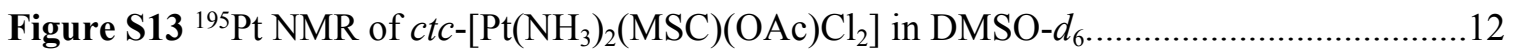

Figure S14 HPLC chromatogram of $\mathbf{1 0}$ ran with $0-100 \%$ linear gradient of acetonitrile in water

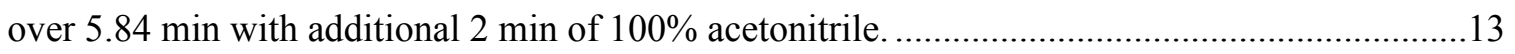

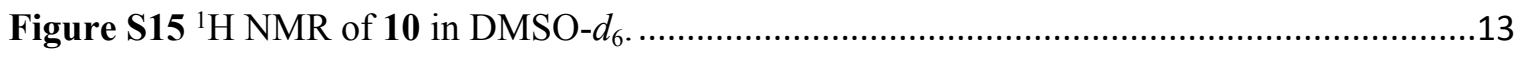

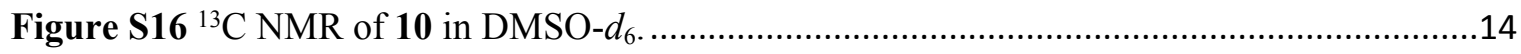

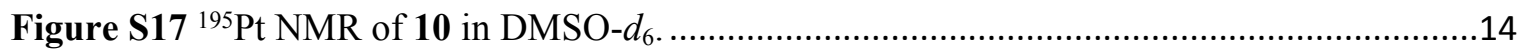

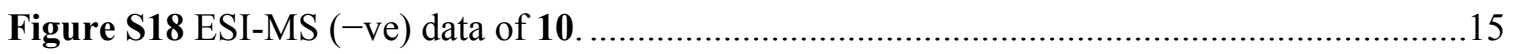

Figure S19 HPLC chromatogram of 1 ran with $0-90 \%$ linear gradient of acetonitrile in water over $11.84 \mathrm{~min}$.

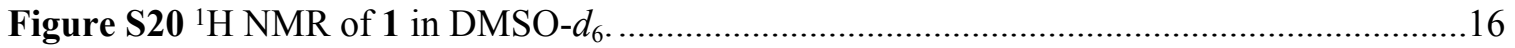

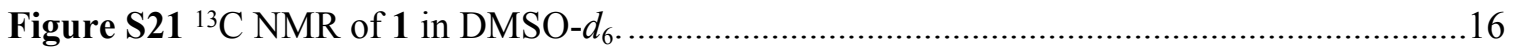

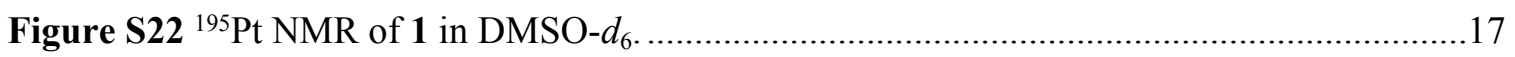

Figure S23 ESI-MS (-ve) data of 1...........................................................17_Toc32152677

Figure S24 HPLC chromatogram of 2 ran with $0-100 \%$ acetonitrile gradient in water over 15 min. 


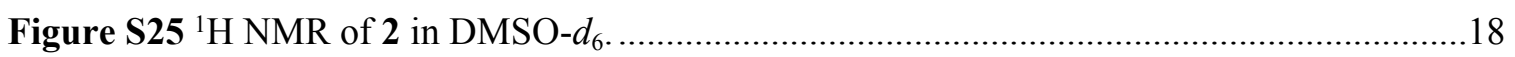

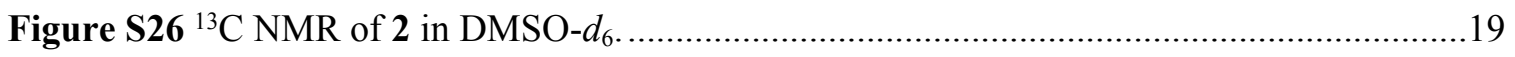

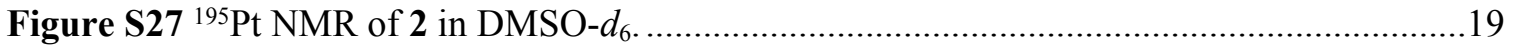

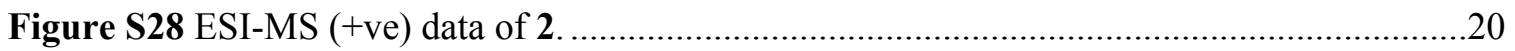

Figure S29 HPLC chromatogram of $\mathbf{3}$ ran with $0-100 \%$ linear gradient acetonitrile gradient in

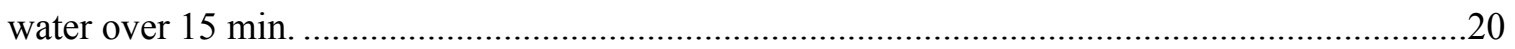

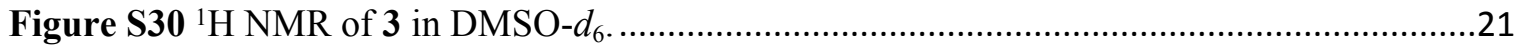

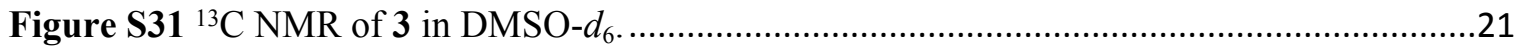

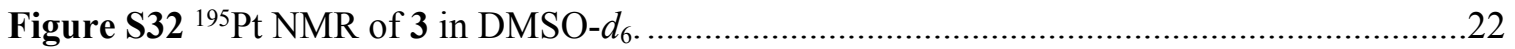

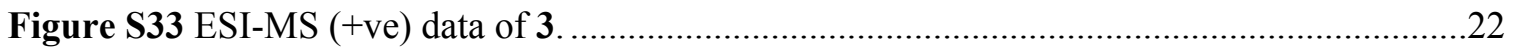

Figure S34 HPLC chromatogram of 4 ran with $0-90 \%$ linear gradient of acetonitrile gradient in water over $30 \mathrm{~min}$. .23

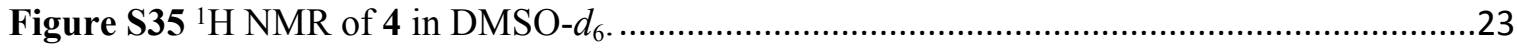

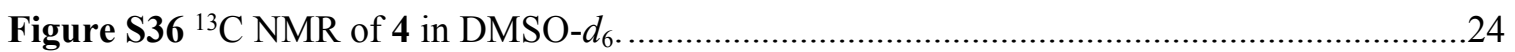

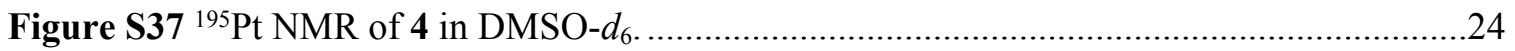

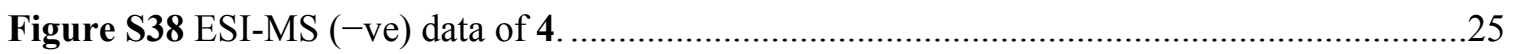

Figure S39 HPLC chromatogram of 5 ran with $0-100 \%$ acetonitrile in 5.84 min then 3 min constant at $100 \%$ acetonitrile. .25

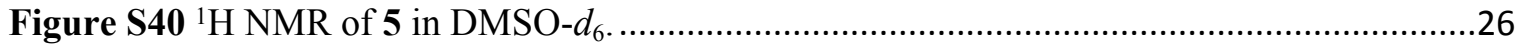

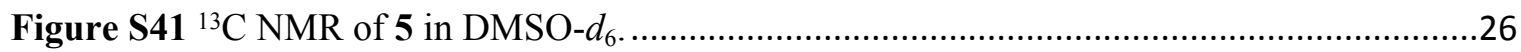

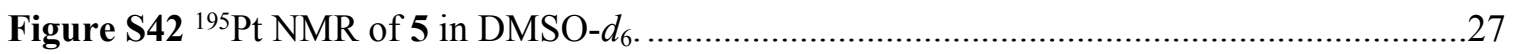

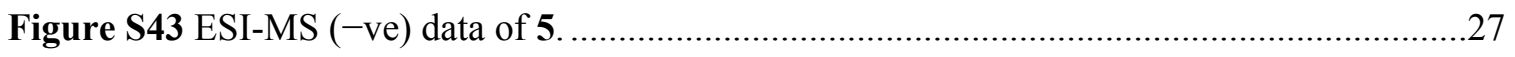

Figure S44 HPLC chromatogram of 6 ran with 0-100\% acetonitrile in 5.84 min then 3 min constant at $100 \%$ acetonitrile. .28

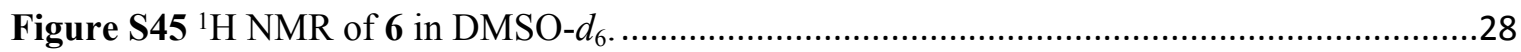

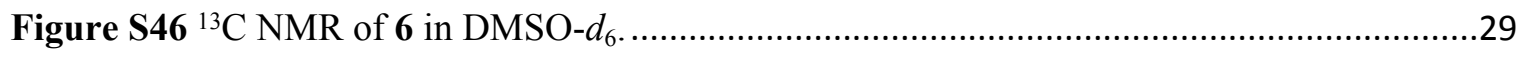

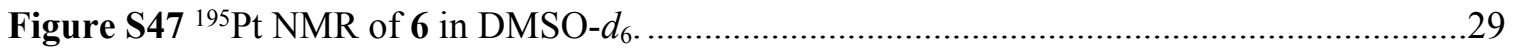

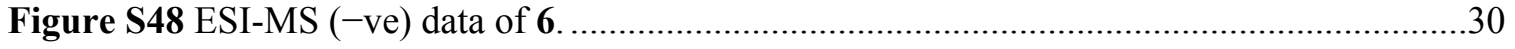

Figure S49 ${ }^{1} \mathrm{H}$ NMR of methyl 8-((4-aminophenyl)amino)-8-oxooctanoate in DMSO- $d_{6} \ldots \ldots . . . . .30$

Figure S50 ${ }^{13} \mathrm{C}$ NMR of methyl 8-((4-aminophenyl)amino)-8-oxooctanoate in DMSO- $d_{6} \ldots \ldots . . . .31$

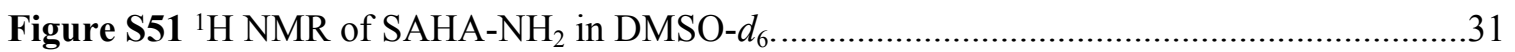

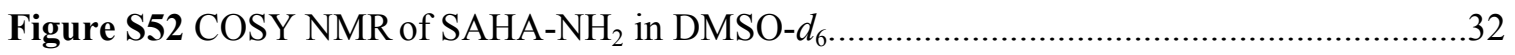

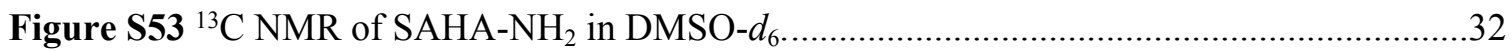


Figure S54 HPLC chromatogram of 7 ran in $(0-60 \%)$ acetonitrile gradient in water over 20 min.

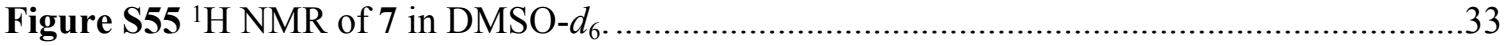

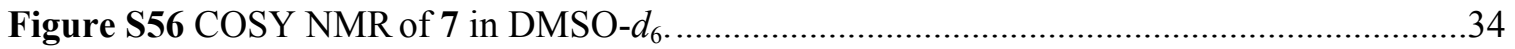



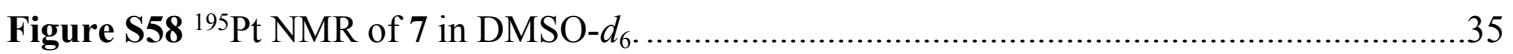

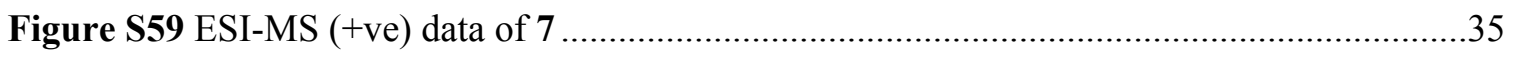

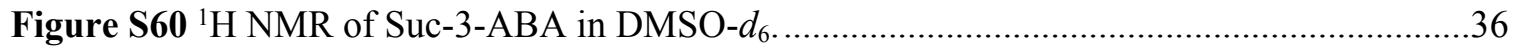

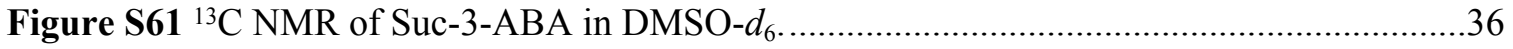

Figure S62 HPLC chromatogram of 11 ran in $0-100 \%$ linear gradient of water to acetonitrile as mobile phase over $5.84 \mathrm{~min}$ then $2 \mathrm{~min}$ constant at $100 \%$ acetonitrile. ......................................37

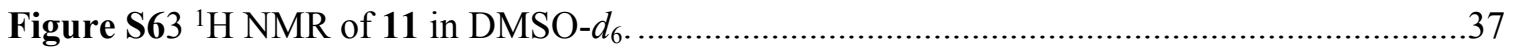

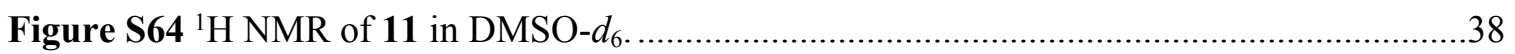

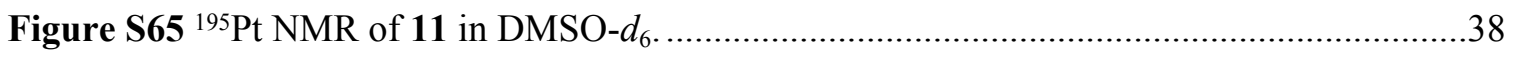

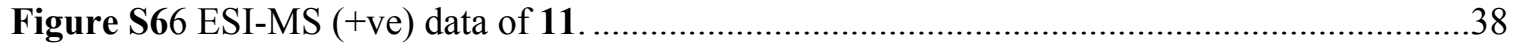

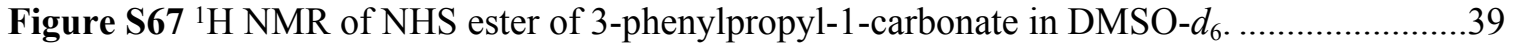

Figure S68 ${ }^{13} \mathrm{C}$ NMR of NHS ester of 3-phenylpropyl-1-carbonate in DMSO- $d_{6} \ldots \ldots \ldots \ldots \ldots \ldots . . . . . . . . . . .39$

Figure S69 ESI-MS (-ve) of NHS ester of 3-phenylpropyl-1-carbonate....................................40

Figure S70 HPLC chromatogram of 9 ran with $0-100 \%$ acetonitrile in $15 \mathrm{~min}$ then 3 min constant at $100 \%$ acetonitrile.

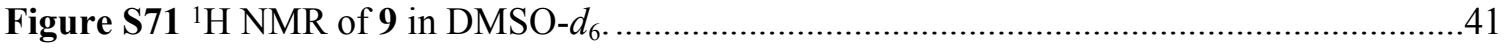

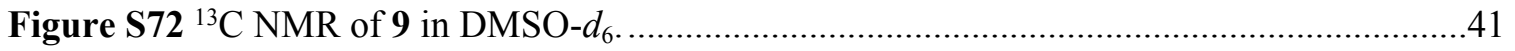

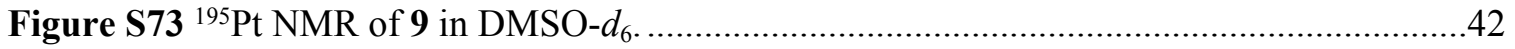

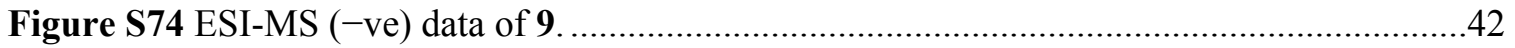

Figure S75 HPLC chromatogram of 7 in presence of 10 equivalents of ascorbic acid taken at different time interval in a 1:1 mixture of methanol \& $100 \mathrm{mM}$ phosphate buffer of $\mathrm{pH} 7.0$ at 37 ${ }^{\circ} \mathrm{C}$.

Figure S76 Stack plot of NMR kinetic data of 7 in presence of 10 equivalents of ascorbic acid in a 1:1 mixture of MeOD- $d_{4} \& 100 \mathrm{mM}$ phosphate buffer of $\mathrm{pH} 7.0$ (prepared in $\mathrm{D}_{2} \mathrm{O}$ ) at $37{ }^{\circ} \mathrm{C}$. The data shows the distinct upfield shift of $\mathrm{H}^{\prime}$ of $\mathrm{Pt}^{\mathrm{IV}}$ complex (blue) forming free $\mathrm{SAHA}-\mathrm{NH}_{2}$ ligand (red) upon reduction followed by decarboxylation.

Figure S77 Half-lives $\left(t_{1 / 2}\right)$ of compounds $1-4$ in cell culture medium. .44

Figure S78 Half-lives $\left(t_{1 / 2}\right)$ of compounds $1-4$ in presence of 10 equivalents of ascorbic acid. .44

Figure S79 ESI-MS (+ve) speciations of the solution containing 11 and 10 eqv ascorbic acid in 100 $\mathrm{mM}$ phosphate buffer of $\mathrm{pH} 7.0$ after 2 days at $37^{\circ} \mathrm{C}$. This data is showing the species mostly from intact succinated 3-ABA. 


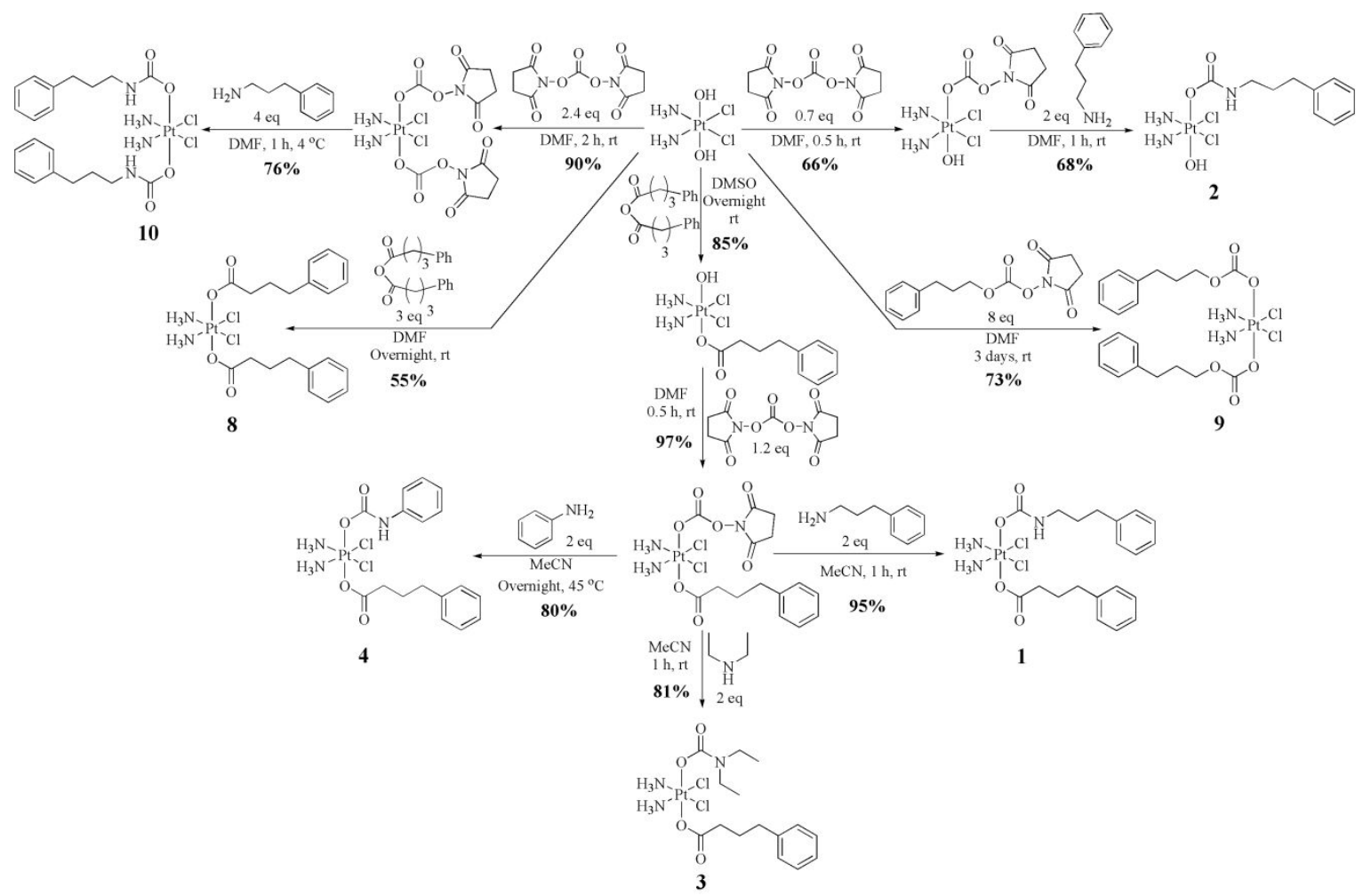

Scheme S1 Synthetic route for the preperation of various cisPt(IV)-carbamato and carbonato complexes starting from oxoplatin.



Scheme S2 Synthetic scheme for the attachment of PARP inhibitor (3-ABA) to the axial position of $\mathrm{Pt}(\mathrm{IV})$ by carbamate and succinate linker respectively. 




Scheme S3 Synthetic scheme for the attachment of HDAC inhibitor $\left(\mathrm{SAHA}-\mathrm{NH}_{2}\right)$ to the axial position of $\mathrm{Pt}(\mathrm{IV})$ by carbamate linkage.

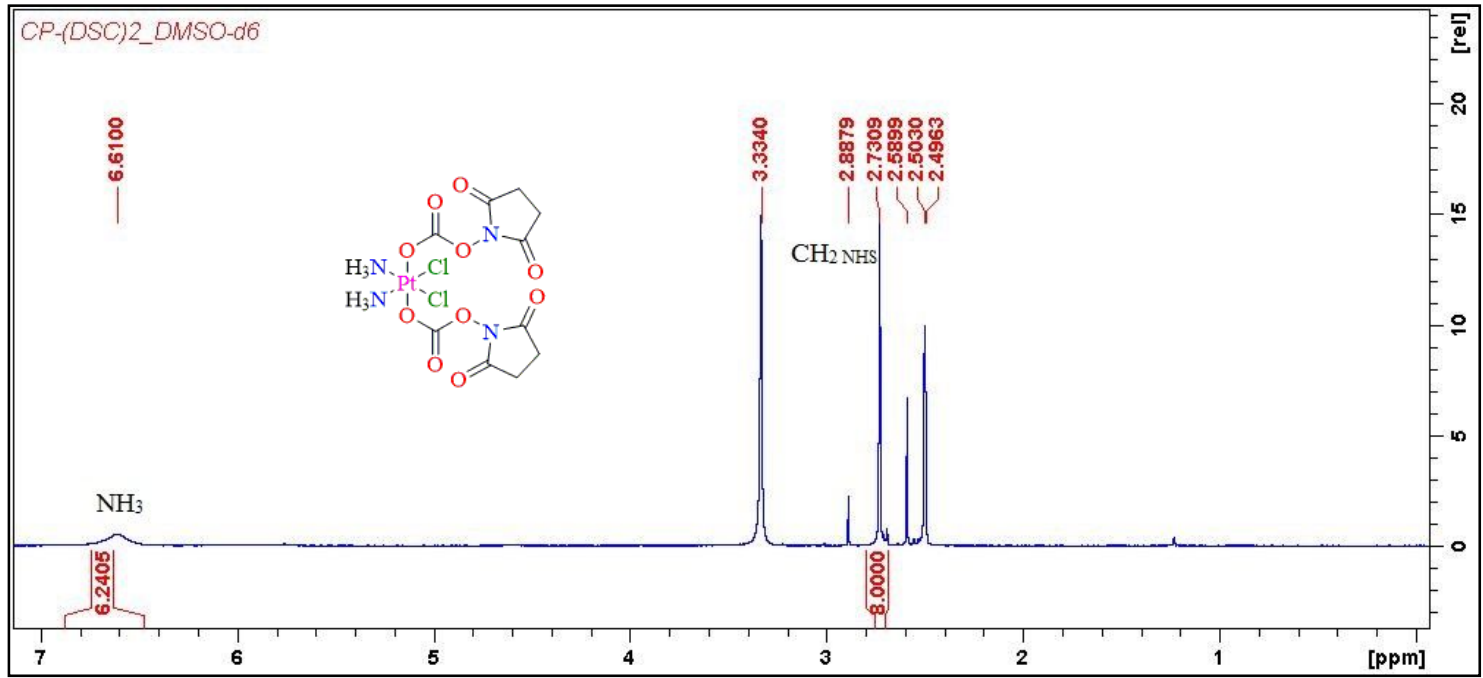

Figure S1 ${ }^{1} \mathrm{H}$ NMR of $c t c$ - $\left[\mathrm{Pt}\left(\mathrm{NH}_{3}\right)_{2}\left(\mathrm{MSC}_{2} \mathrm{Cl}_{2}\right]\right.$ in DMSO- $d_{6}$. 


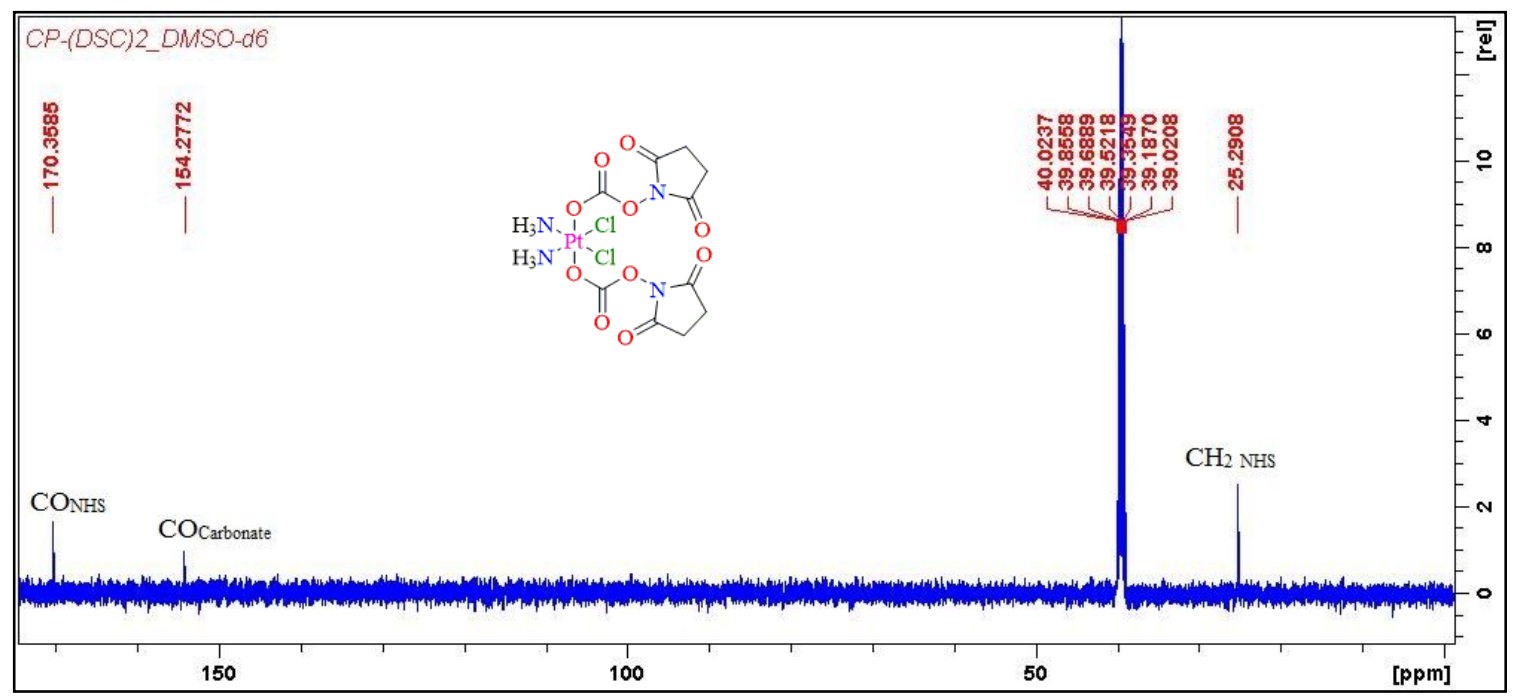

Figure S2 ${ }^{13} \mathrm{C} \mathrm{NMR}$ of $c t c-\left[\mathrm{Pt}\left(\mathrm{NH}_{3}\right)_{2}(\mathrm{MSC})_{2} \mathrm{Cl}_{2}\right]$ in DMSO- $d_{6}$.

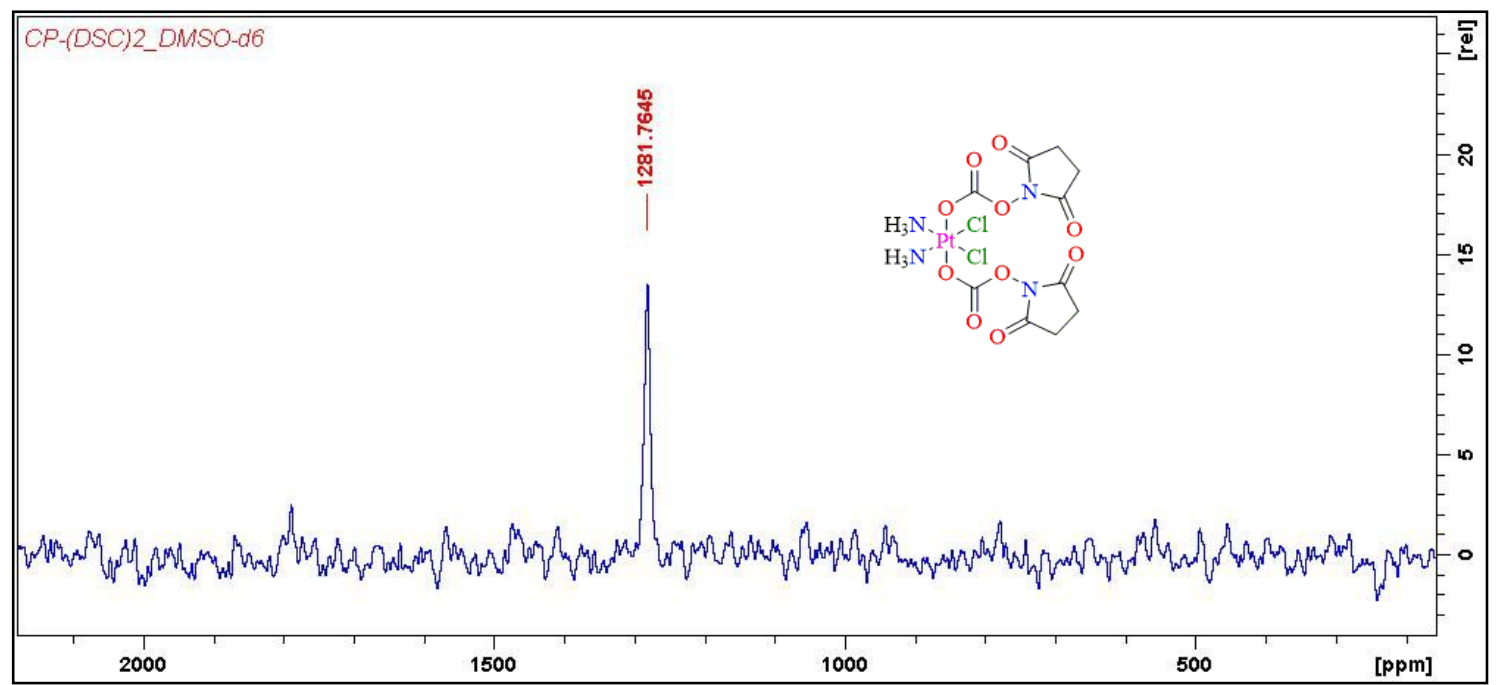

Figure $\mathbf{S 3}{ }^{195} \mathrm{Pt} \mathrm{NMR}$ of $c t c$ - $\left[\mathrm{Pt}\left(\mathrm{NH}_{3}\right)_{2}(\mathrm{MSC})_{2} \mathrm{Cl}_{2}\right]$ in DMSO- $d_{6}$. 


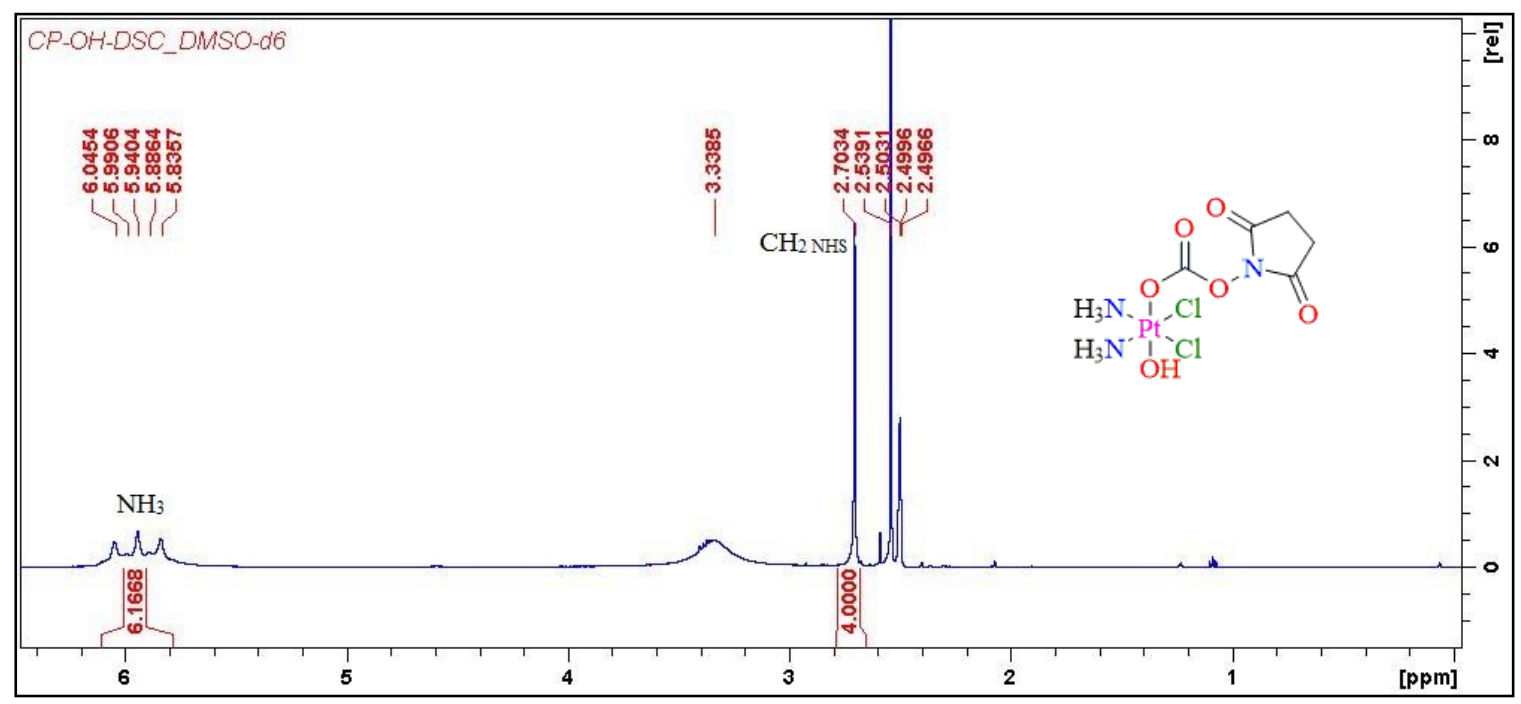

Figure $\mathbf{S 4}{ }^{1} \mathrm{H}$ NMR of $c t c-\left[\mathrm{Pt}\left(\mathrm{NH}_{3}\right)_{2}(\mathrm{MSC})(\mathrm{OH}) \mathrm{Cl}_{2}\right]$ in DMSO- $d_{6}$.

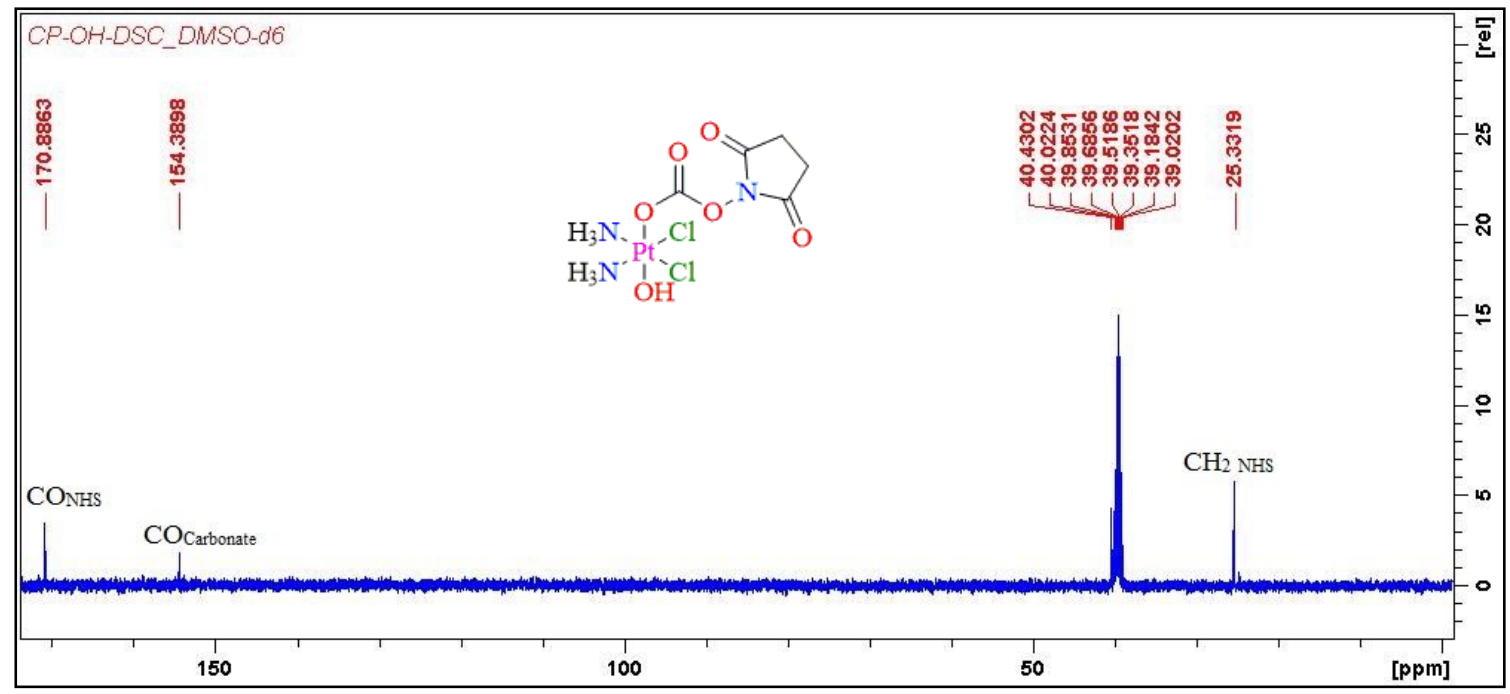

Figure $\mathbf{S 5}{ }^{13} \mathrm{C} \mathrm{NMR}$ of $c t c$ - $\left[\mathrm{Pt}\left(\mathrm{NH}_{3}\right)_{2}(\mathrm{MSC})(\mathrm{OH}) \mathrm{Cl}_{2}\right]$ in DMSO- $d_{6}$. 


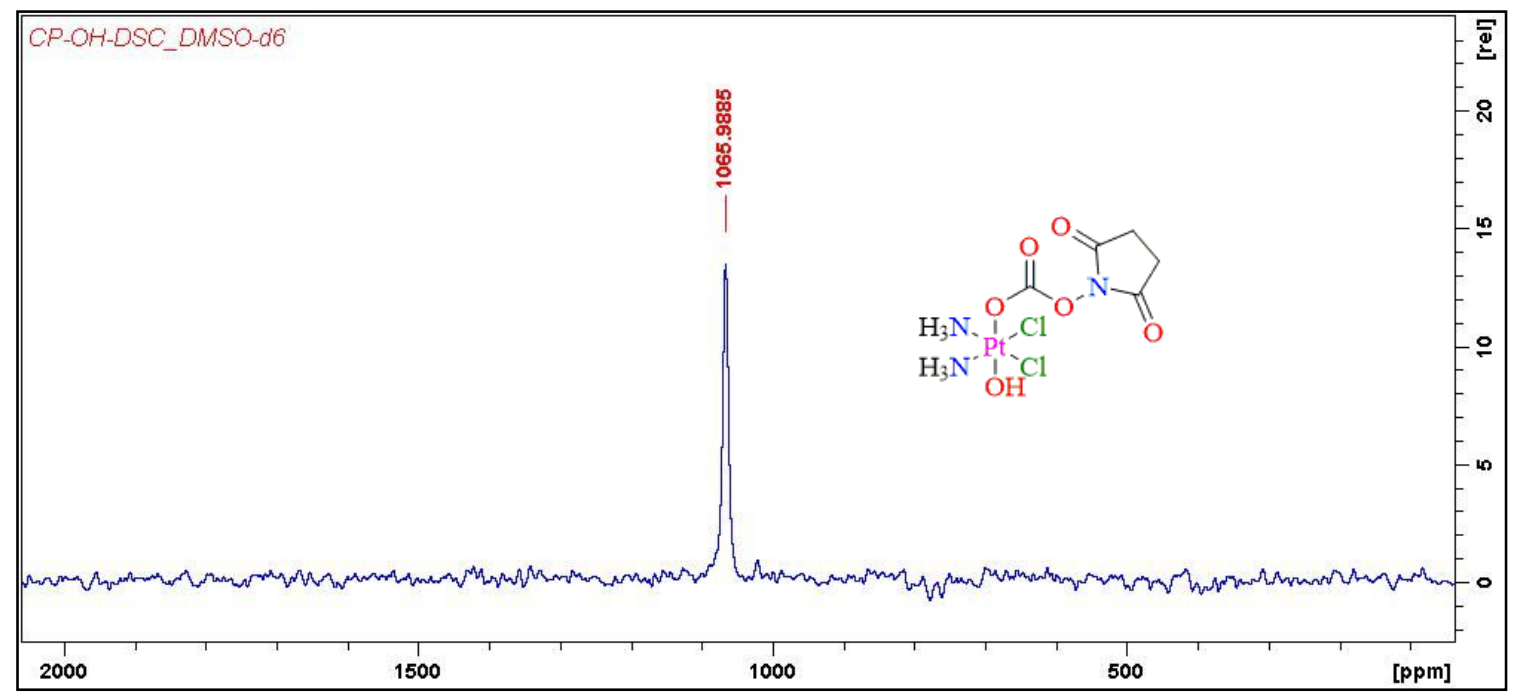

Figure S6 ${ }^{195} \mathrm{Pt} \mathrm{NMR}$ of $c t c-\left[\mathrm{Pt}\left(\mathrm{NH}_{3}\right)_{2}(\mathrm{MSC})(\mathrm{OH}) \mathrm{Cl}_{2}\right]$ in DMSO- $d_{6}$.

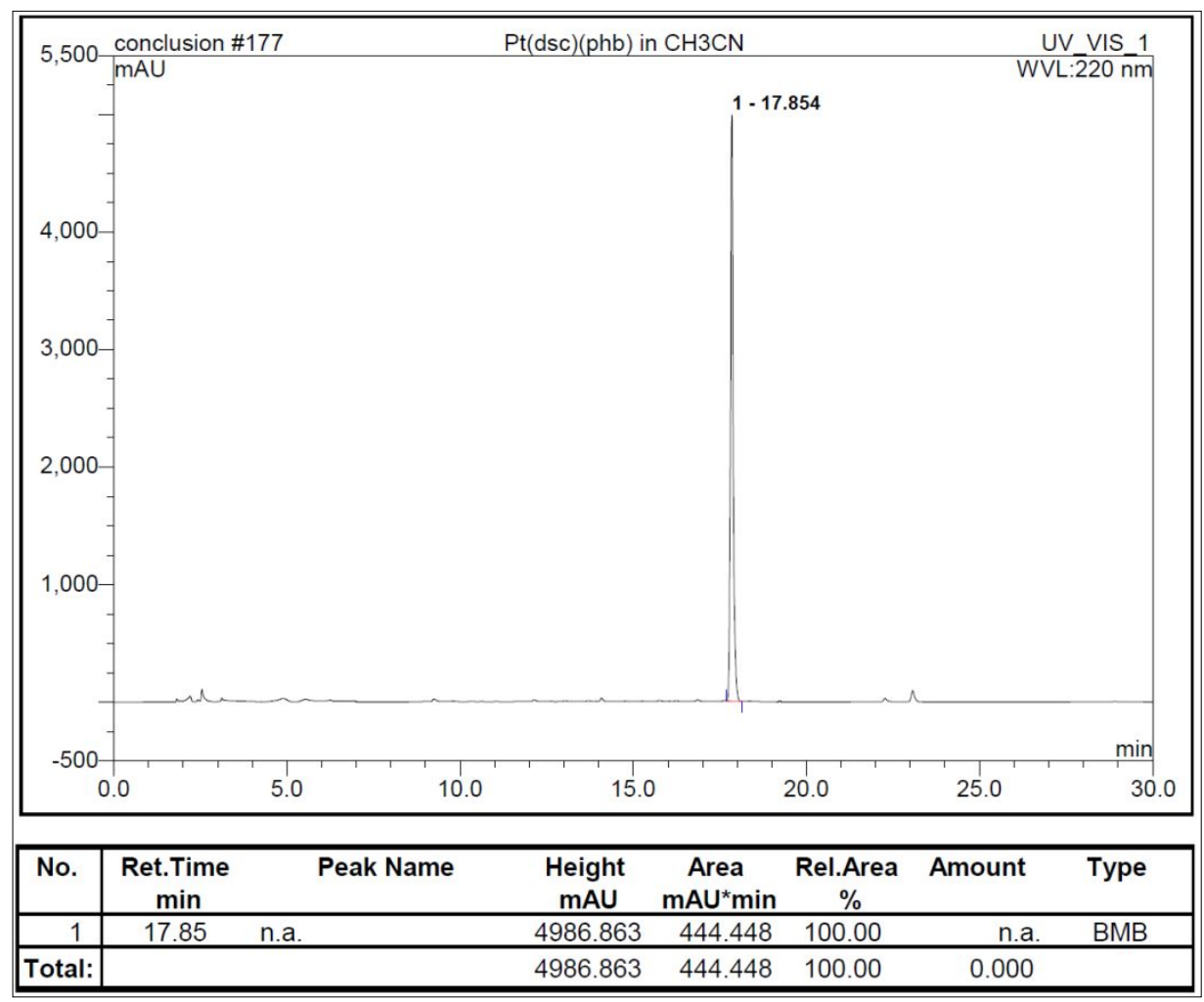

Figure S7 HPLC chromatogram of $c t c-\left[\mathbf{P t}\left(\mathbf{N H}_{3}\right)_{2}(\mathbf{M S C})(\mathbf{P h B}) \mathbf{C l}_{2}\right]$ ran in $(0-90 \%)$ acetonitrile gradient in water over $30 \mathrm{~min}$. 


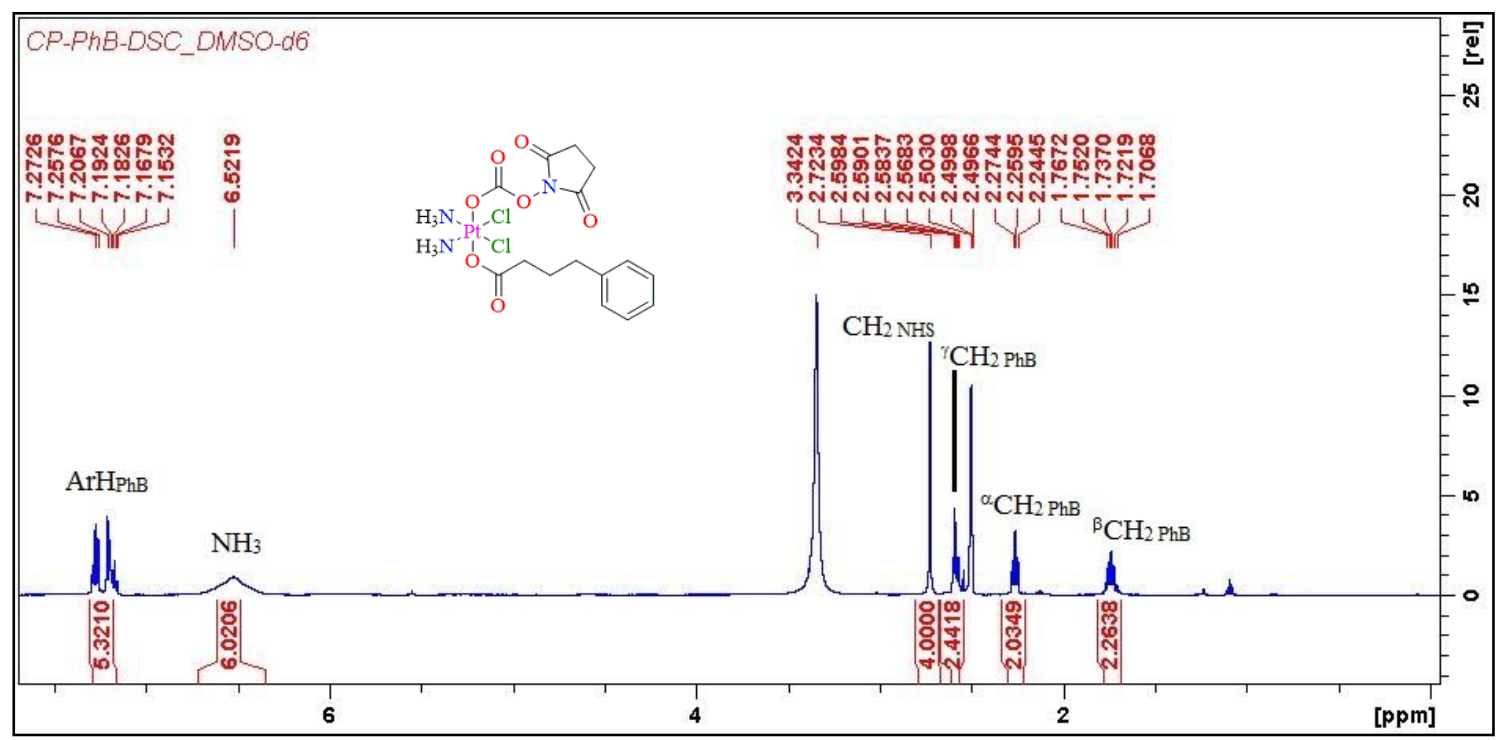

Figure S8 ${ }^{1} \mathrm{H}$ NMR of $c t c-\left[\mathrm{Pt}\left(\mathrm{NH}_{3}\right)_{2}(\mathrm{MSC})(\mathrm{PhB}) \mathrm{Cl}_{2}\right]$ in DMSO- $d_{6}$.

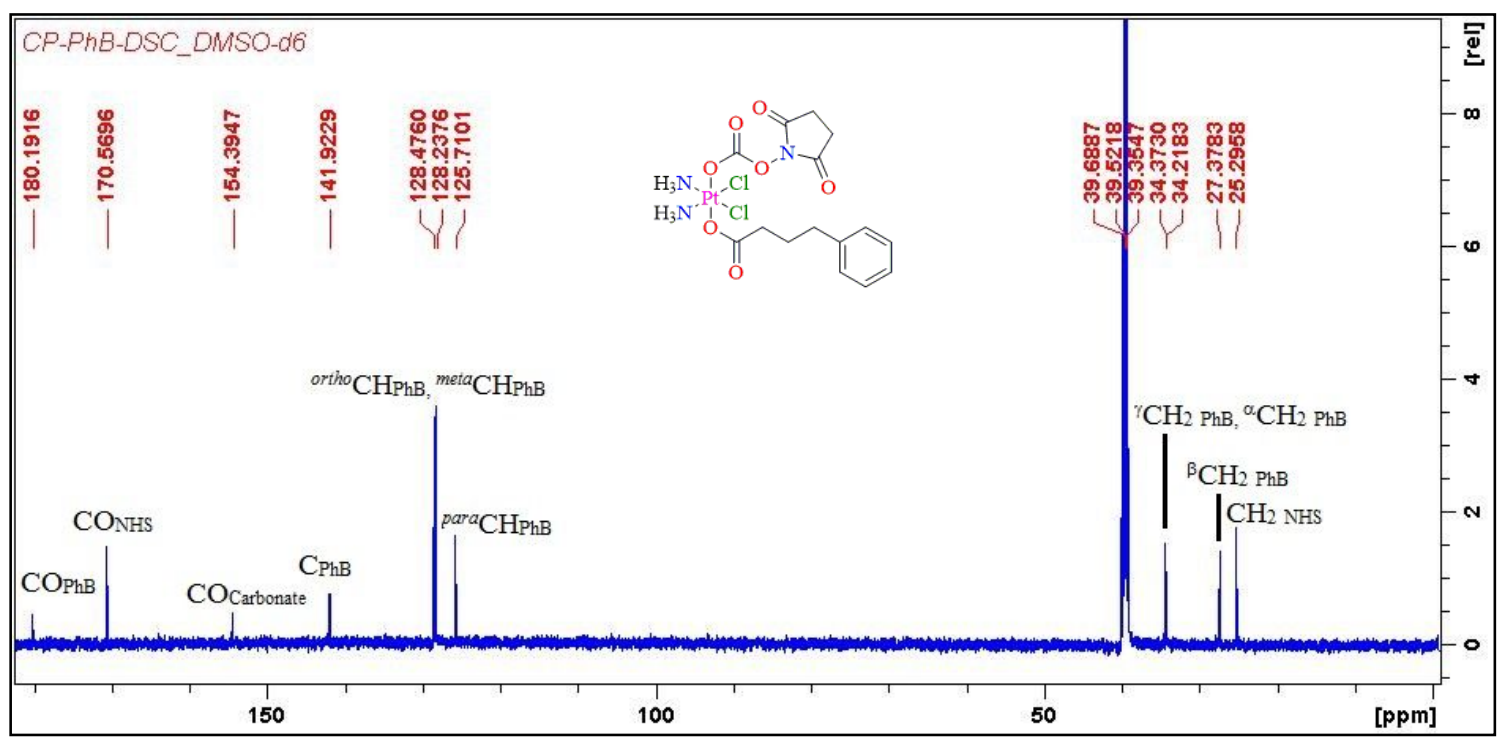

Figure S9 ${ }^{13} \mathrm{C} \mathrm{NMR}$ of $c t c-\left[\mathrm{Pt}\left(\mathrm{NH}_{3}\right)_{2}(\mathrm{MSC})(\mathrm{PhB}) \mathrm{Cl}_{2}\right]$ in $\mathrm{DMSO}-d_{6}$. 


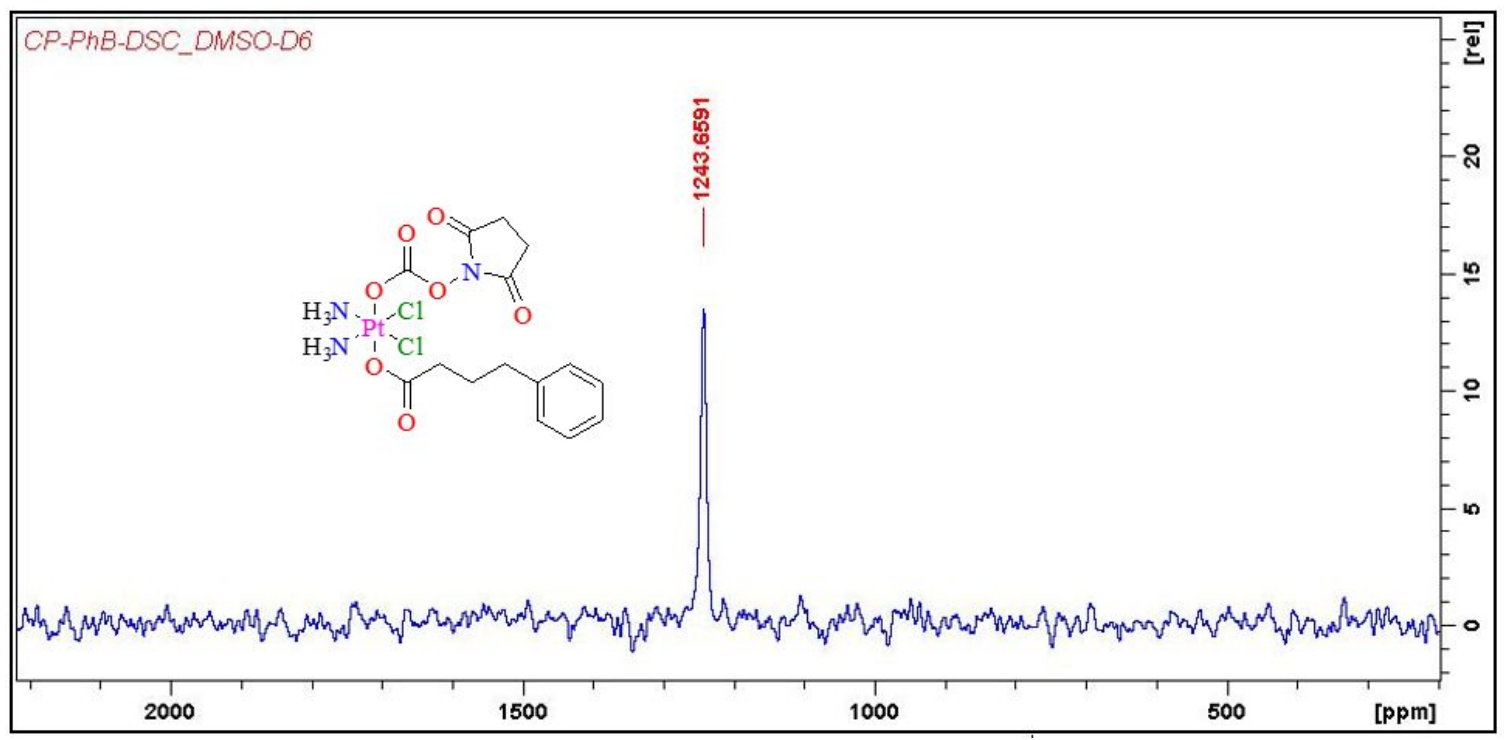

Figure S10 ${ }^{195} \mathrm{Pt} \mathrm{NMR}$ of $c t c-\left[\mathrm{Pt}\left(\mathrm{NH}_{3}\right)_{2}(\mathrm{MSC})(\mathrm{PhB}) \mathrm{Cl}_{2}\right]$ in DMSO- $d_{6}$.

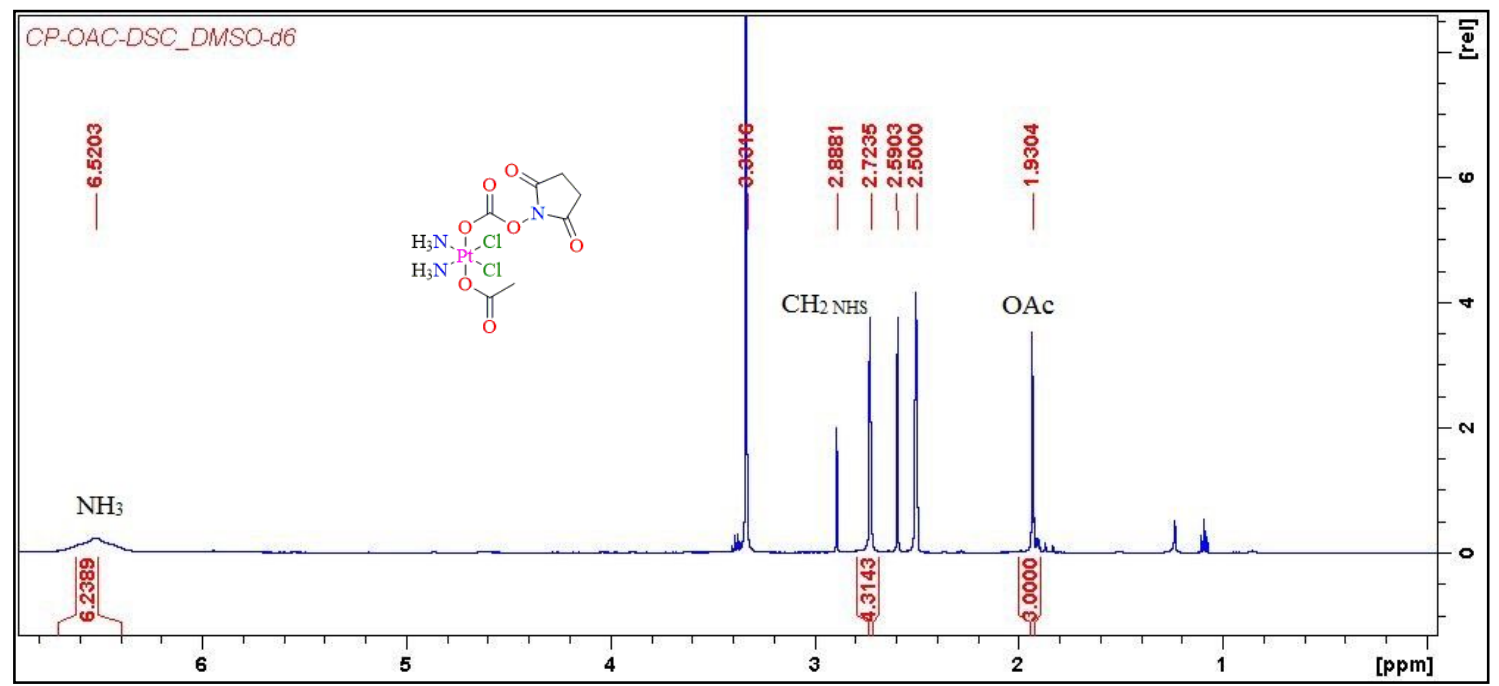

Figure $\mathbf{S 1 1}{ }^{1} \mathrm{H}$ NMR of $c t c-\left[\mathrm{Pt}\left(\mathrm{NH}_{3}\right)_{2}(\mathrm{MSC})(\mathrm{OAc}) \mathrm{Cl}_{2}\right]$ in DMSO- $d_{6}$. 


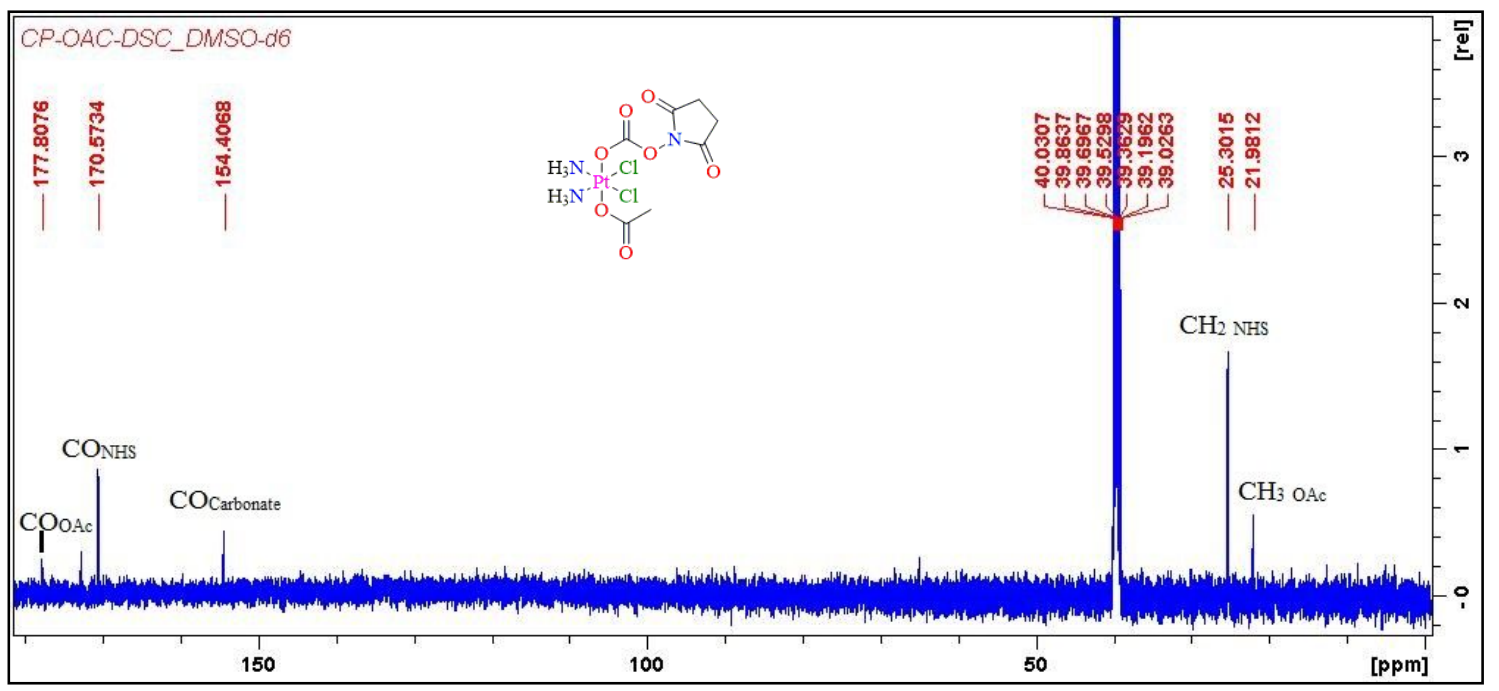

Figure S12 ${ }^{13} \mathrm{C}$ NMR of $c t c-\left[\mathrm{Pt}\left(\mathrm{NH}_{3}\right)_{2}(\mathrm{MSC})(\mathrm{OAc}) \mathrm{Cl}_{2}\right]$ in DMSO- $d_{6}$.

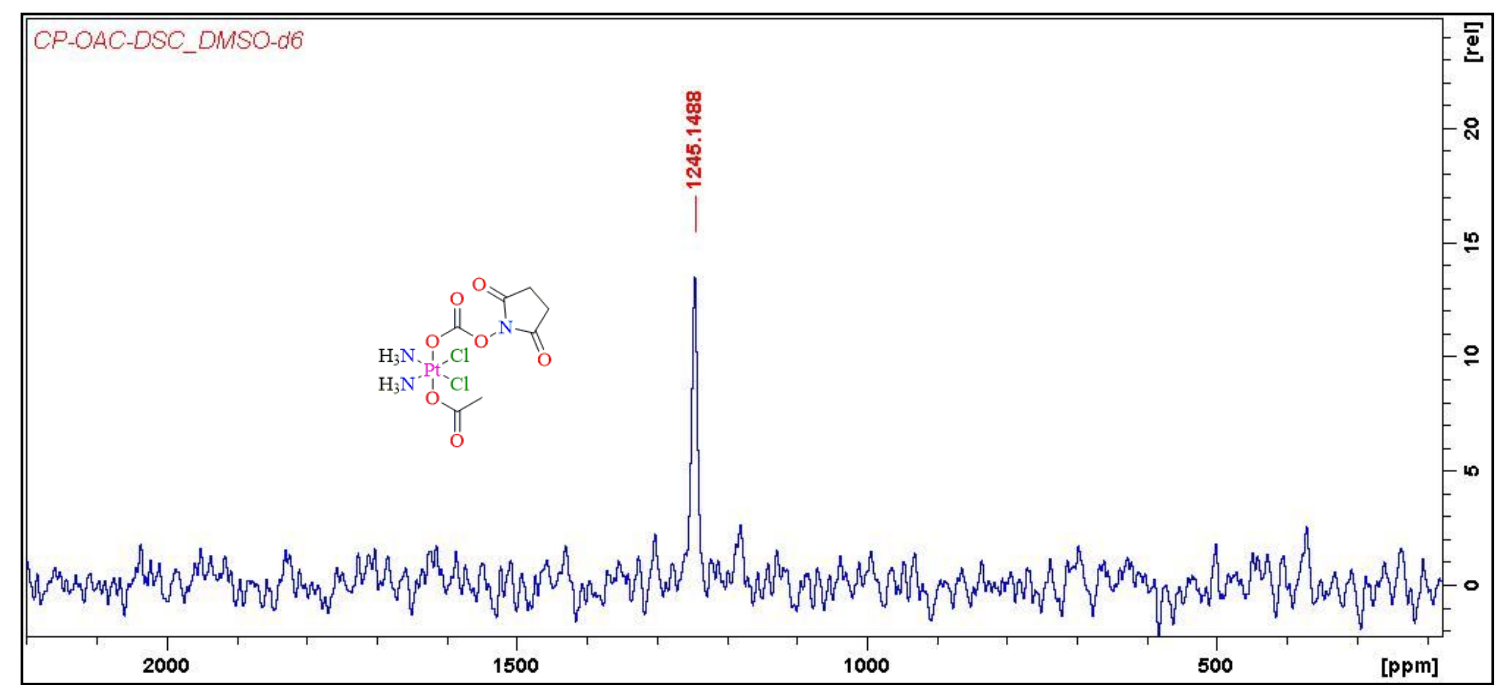

Figure S13 ${ }^{195} \mathrm{Pt} \mathrm{NMR}$ of $c t c-\left[\mathrm{Pt}\left(\mathrm{NH}_{3}\right)_{2}(\mathrm{MSC})(\mathrm{OAc}) \mathrm{Cl}_{2}\right]$ in DMSO- $d_{6}$. 


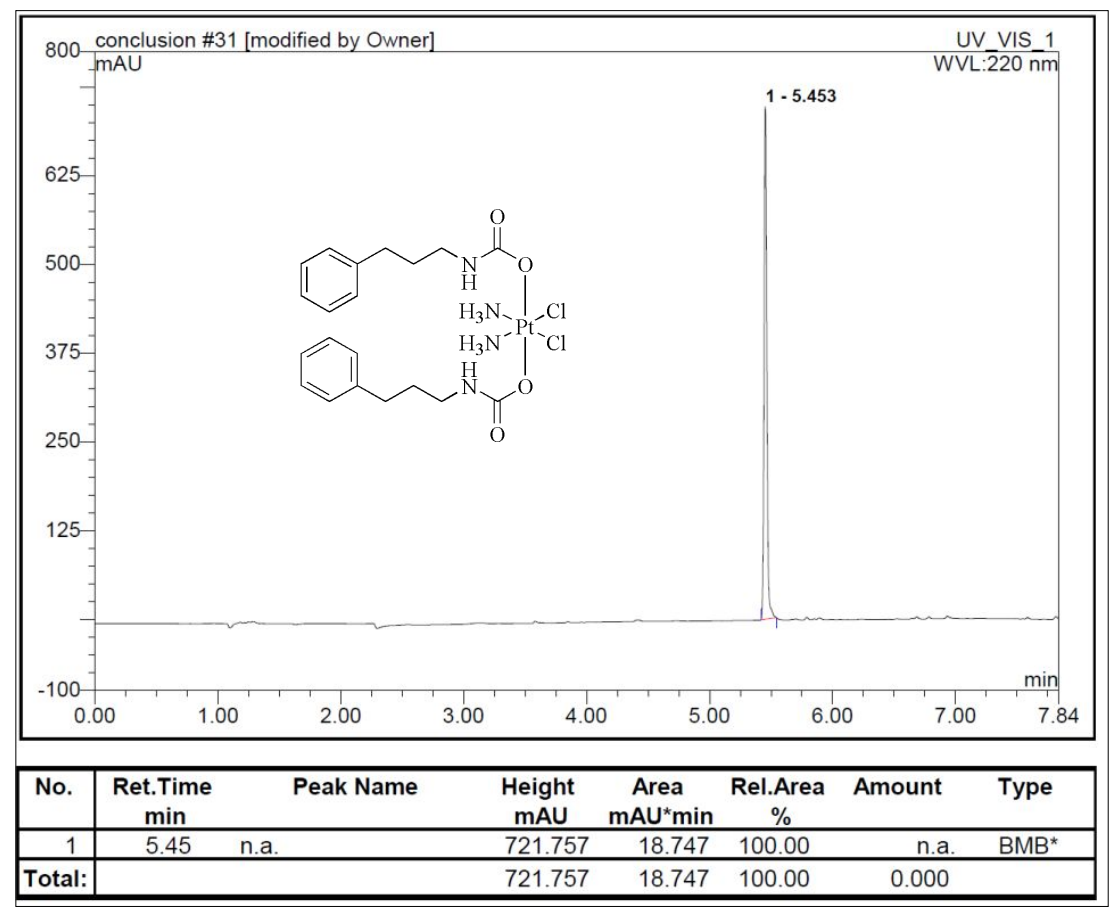

Figure S14 HPLC chromatogram of 10 ran with $0-100 \%$ linear gradient of acetonitrile in water over $5.84 \mathrm{~min}$ with additional $2 \mathrm{~min}$ of $100 \%$ acetonitrile.

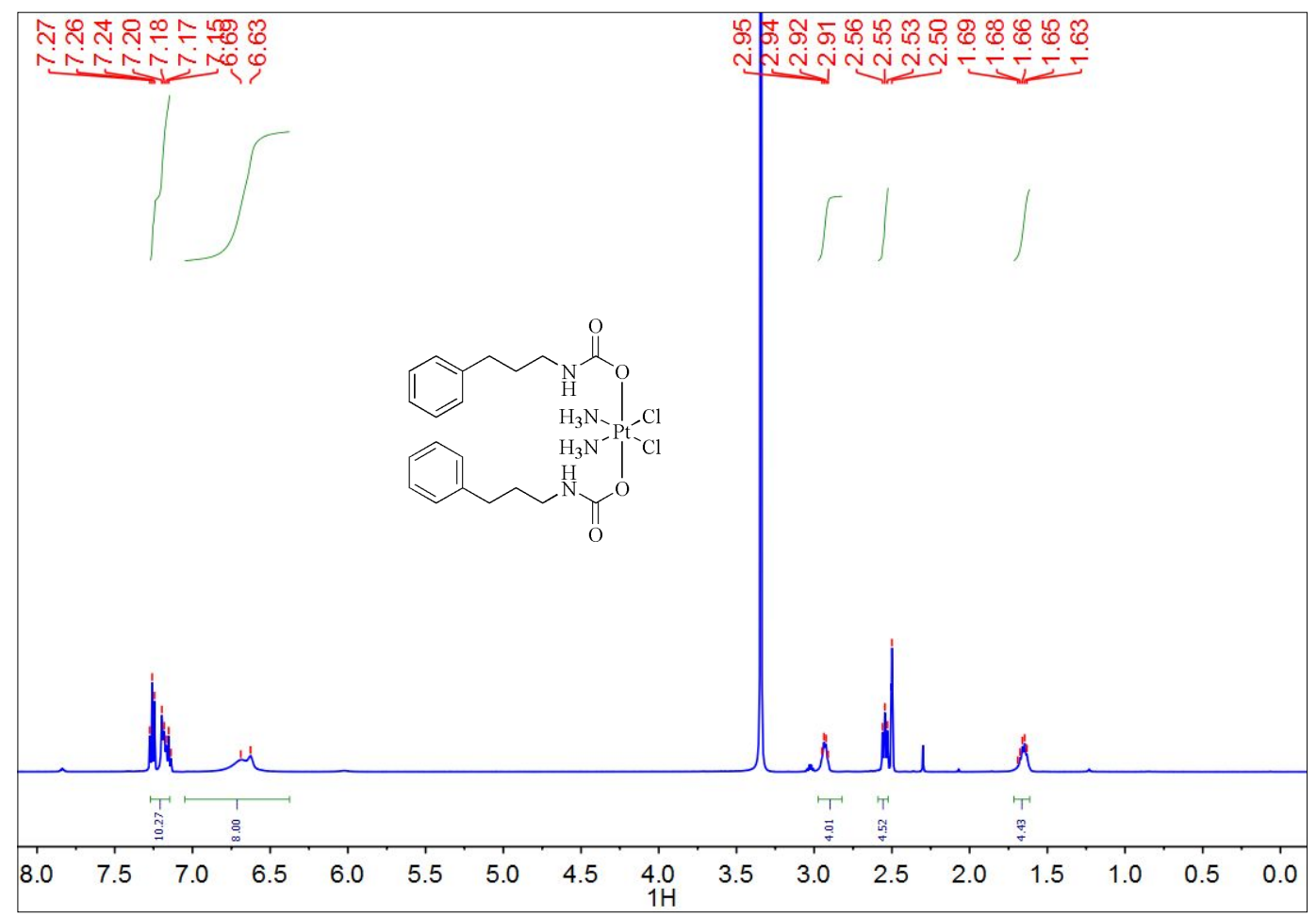

Figure S15 ${ }^{1} \mathrm{H}$ NMR of 10 in DMSO- $d_{6}$. 


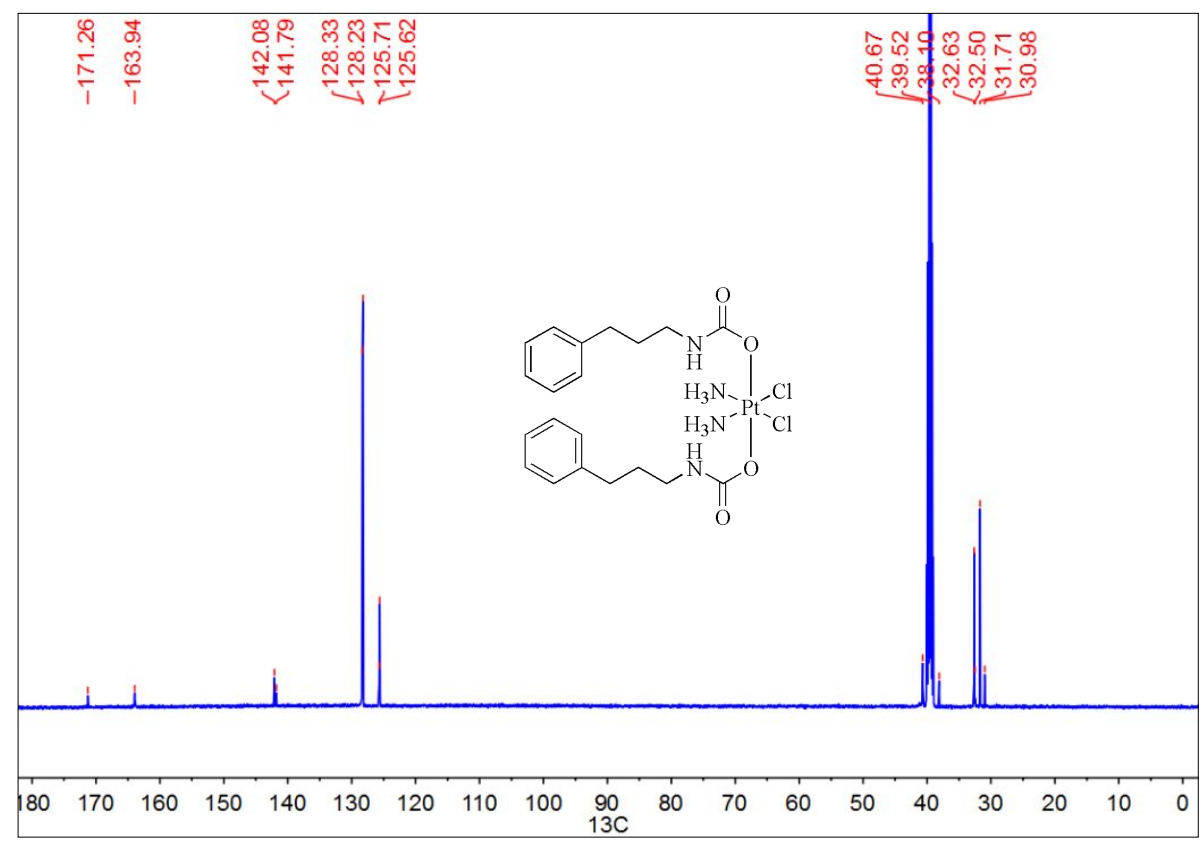

Figure S16 ${ }^{13} \mathrm{C}$ NMR of 10 in DMSO- $d_{6}$.

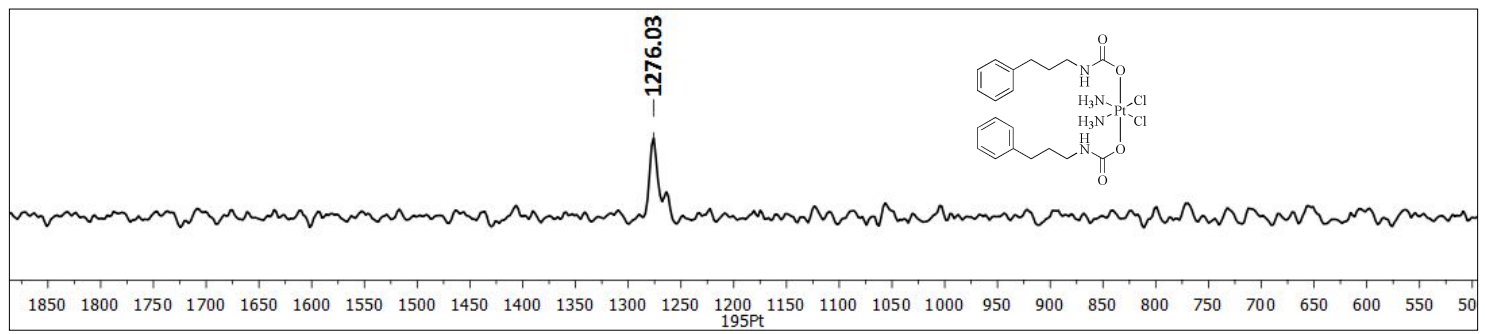

Figure S17 ${ }^{195}$ Pt NMR of 10 in DMSO- $d_{6}$. 


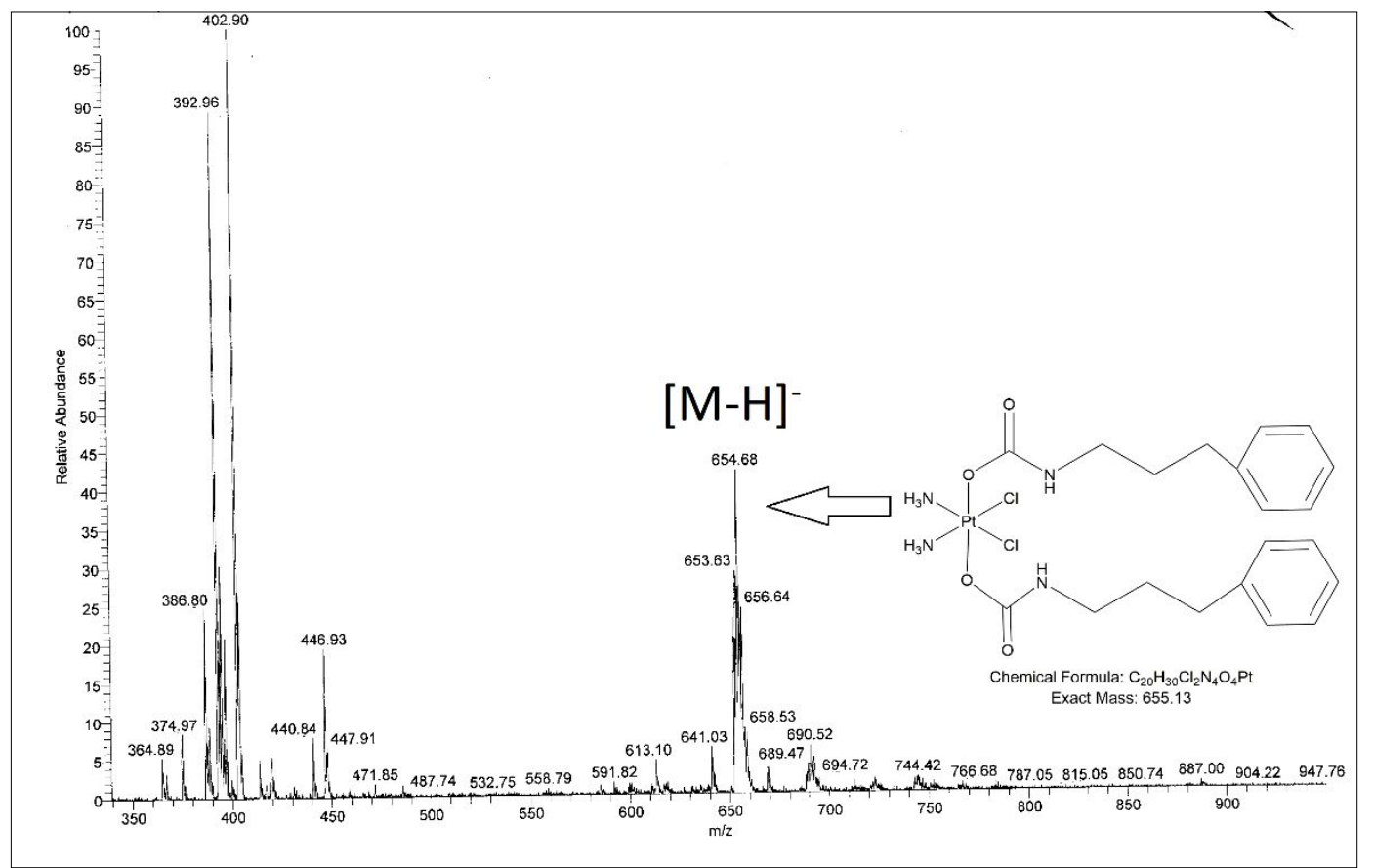

Figure S18 ESI-MS (-ve) data of 10.

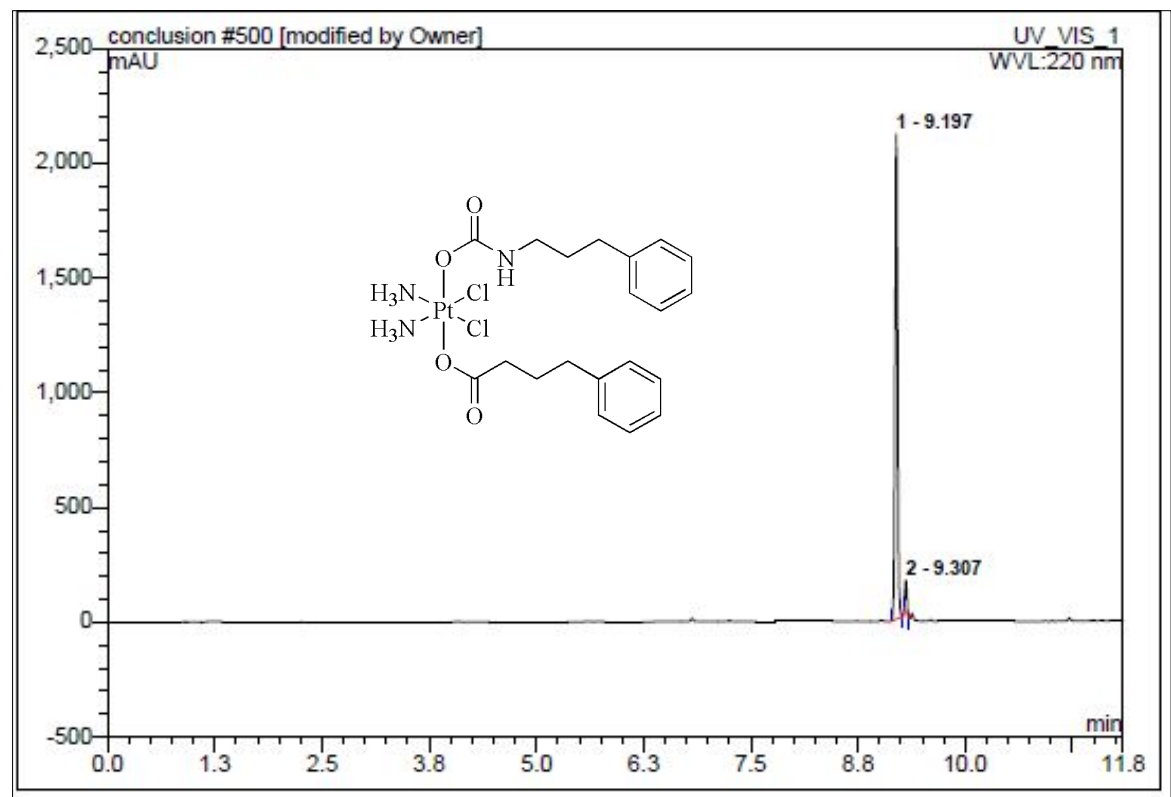

\begin{tabular}{|c|c|c|c|c|c|c|c|}
\hline No. & $\begin{array}{c}\text { Ret.Time } \\
\text { min }\end{array}$ & Peak Name & $\begin{array}{c}\text { Height } \\
\text { mAU }\end{array}$ & $\begin{array}{c}\text { Area } \\
\mathrm{mAU}^{\star} \mathrm{min}\end{array}$ & $\begin{array}{c}\text { Rel.Area } \\
\% \\
\end{array}$ & Amount & Type \\
\hline 1 & 9.20 & n.a. & 2112.070 & 73.779 & 95.17 & n.a. & $\mathrm{BMB}$ \\
\hline 2 & 9.31 & n.a. & 135.836 & 3.746 & 4.83 & n.a. & $\mathrm{BMB}^{\star}$ \\
\hline Total: & & & 2247.905 & 77.525 & 100.00 & 0.000 & \\
\hline
\end{tabular}

Figure S19 HPLC chromatogram of 1 ran with $0-90 \%$ linear gradient of acetonitrile in water over $11.84 \mathrm{~min}$. 


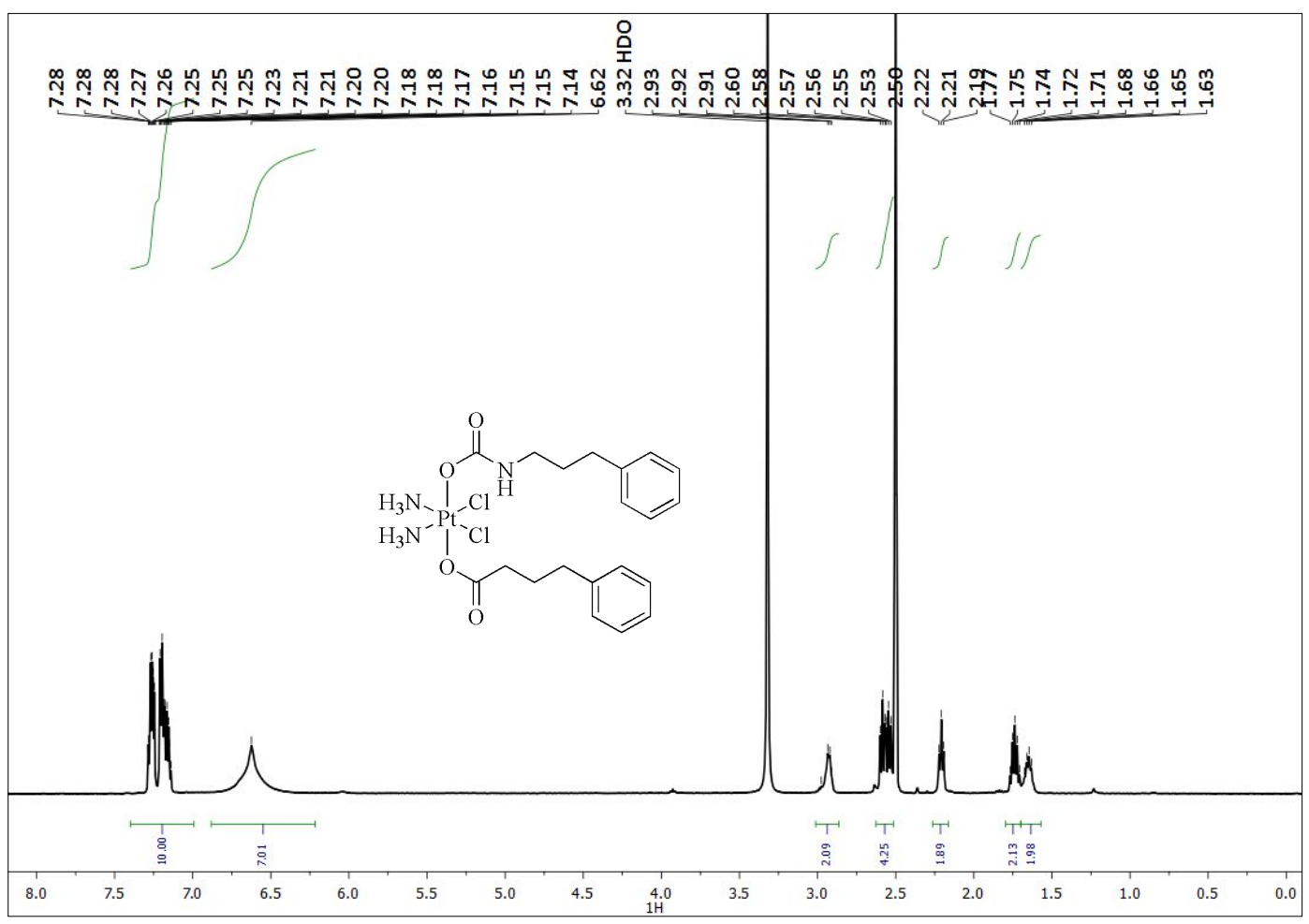

Figure S20 ${ }^{1} \mathrm{H}$ NMR of 1 in DMSO- $d_{6}$.

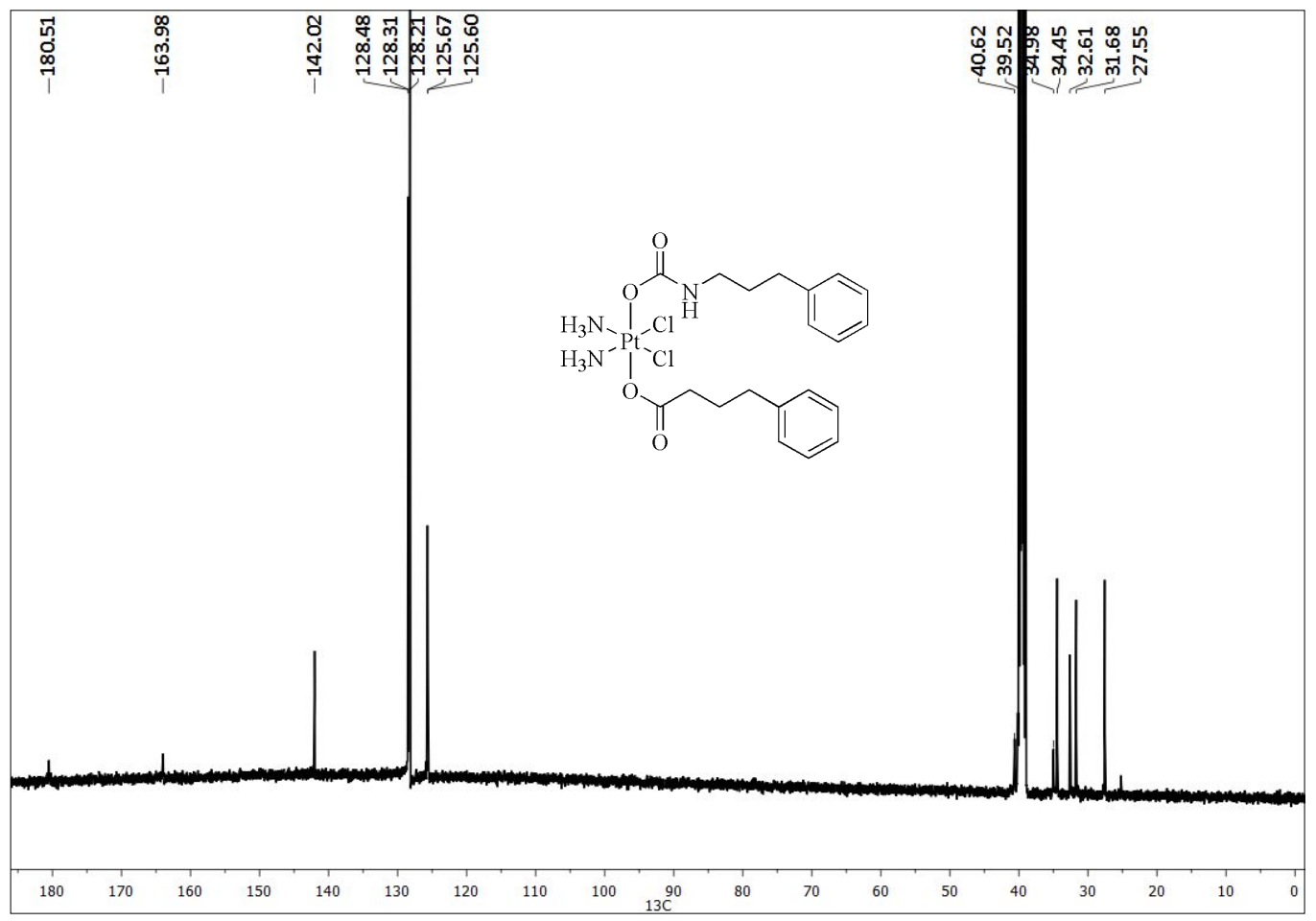

Figure S21 ${ }^{13}$ C NMR of 1 in DMSO- $d_{6}$. 


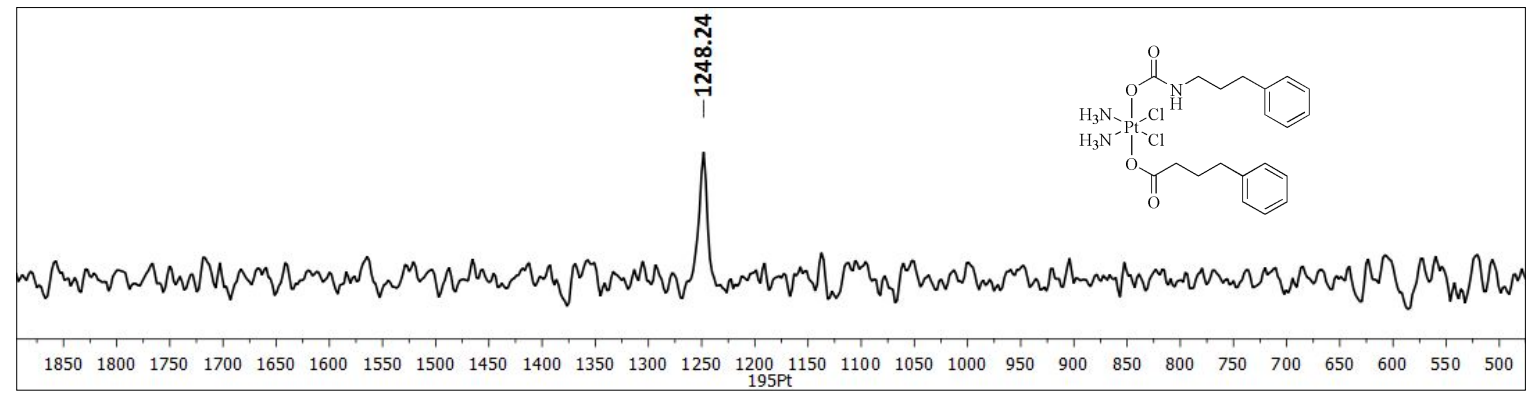

Figure S22 ${ }^{195} \mathrm{Pt}$ NMR of 1 in DMSO- $d_{6}$.

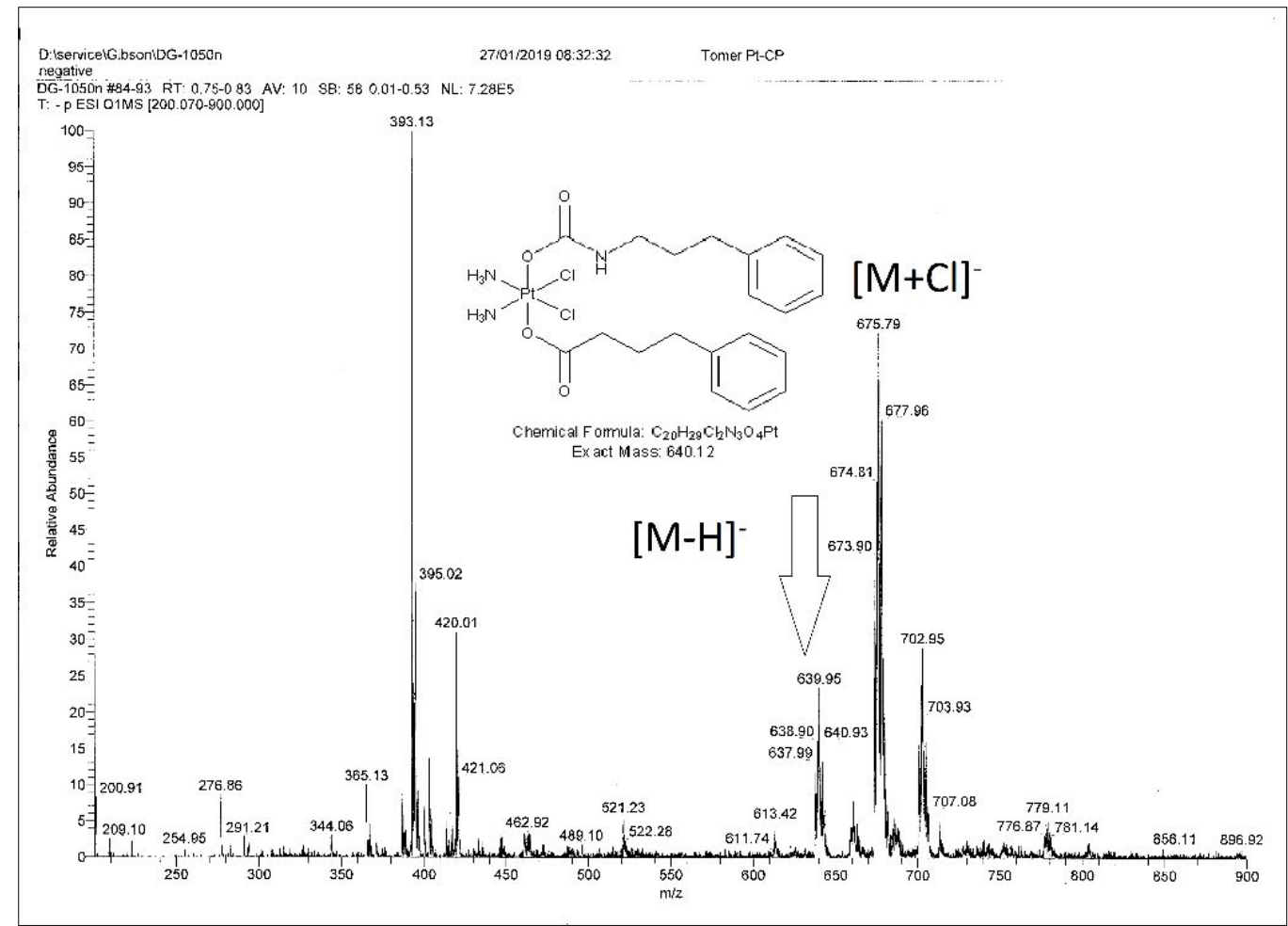

Figure S23 ESI-MS (-ve) data of 1. 


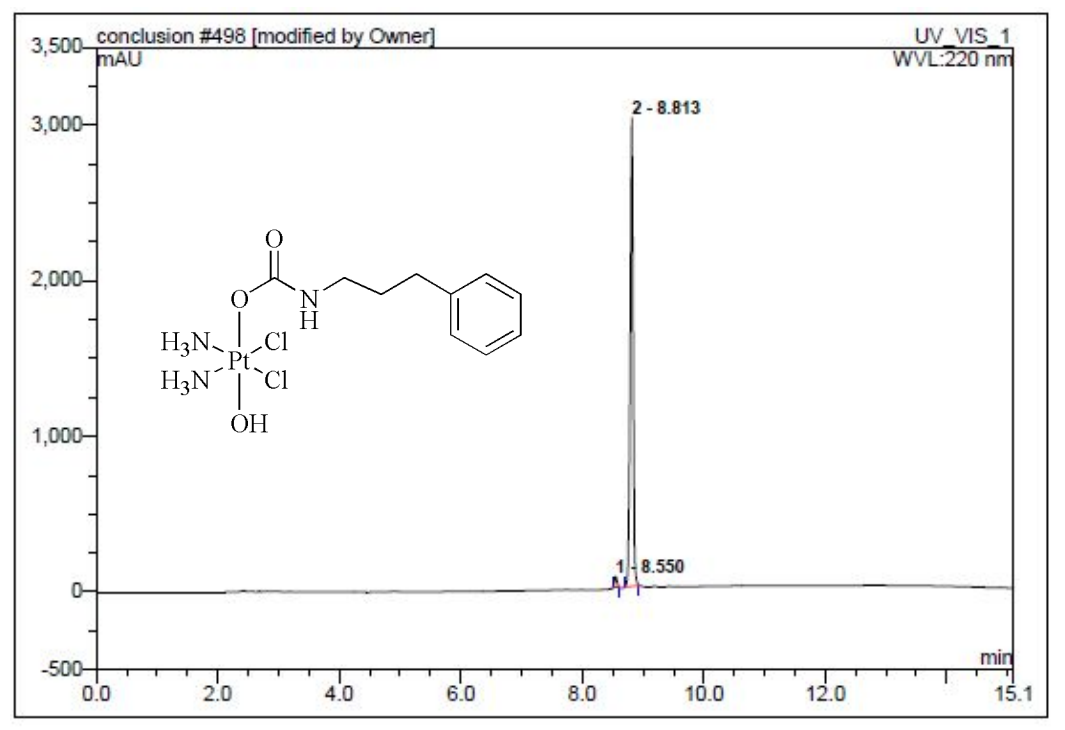

\begin{tabular}{|r|ccrrrrr|}
\hline No. & $\begin{array}{c}\text { Ret.Time } \\
\text { min }\end{array}$ & Peak Name & $\begin{array}{c}\text { Height } \\
\text { mAU }\end{array}$ & $\begin{array}{c}\text { Area } \\
\text { mAU*min }\end{array}$ & $\begin{array}{r}\text { Rel.Area } \\
\%\end{array}$ & Amount & Type \\
\hline 1 & 8.55 & n.a. & 68.835 & 3.204 & 1.85 & n.a. & BMB $^{*}$ \\
2 & 8.81 & n.a. & 3011.615 & 170.286 & 98.15 & n.a. & BMB $^{*}$ \\
\hline Total: & & & 3080.451 & 173.490 & 100.00 & 0.000 & \\
\hline
\end{tabular}

Figure S24 HPLC chromatogram of 2 ran with $0-100 \%$ acetonitrile gradient in water over $15 \mathrm{~min}$.

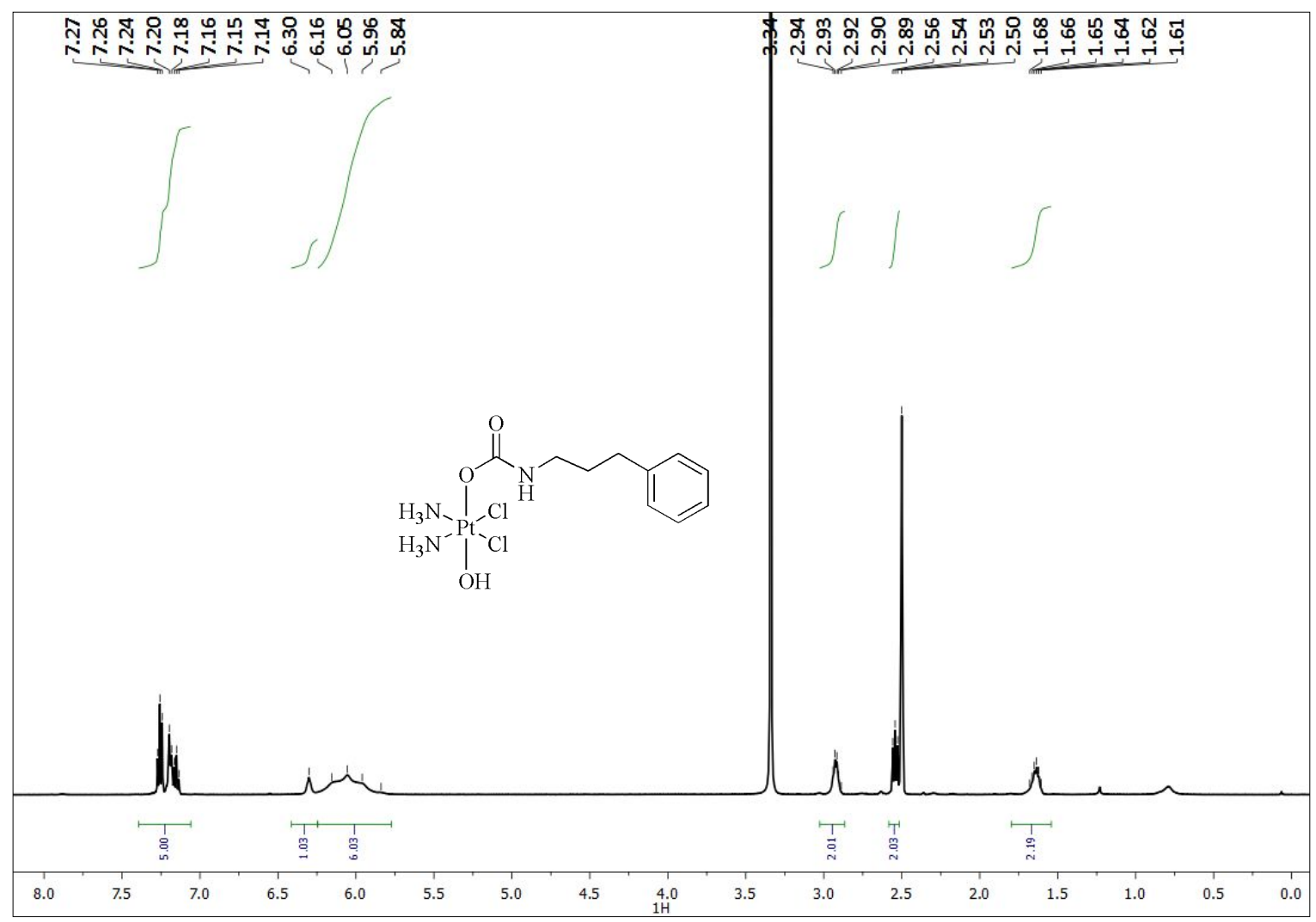

Figure S25 ${ }^{1}$ H NMR of 2 in DMSO- $d_{6}$. 


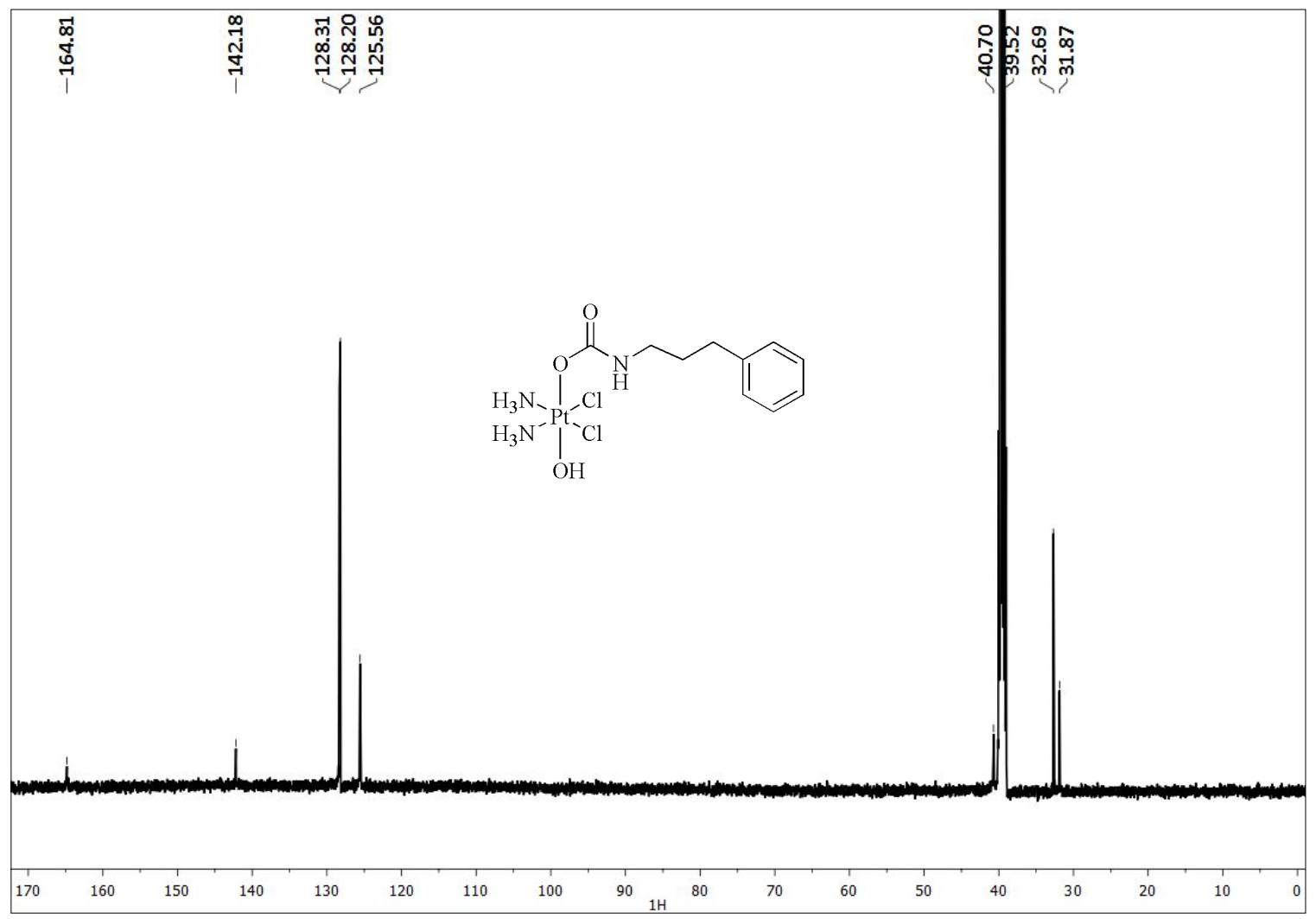

Figure S26 ${ }^{13} \mathrm{C}$ NMR of 2 in DMSO- $d_{6}$.

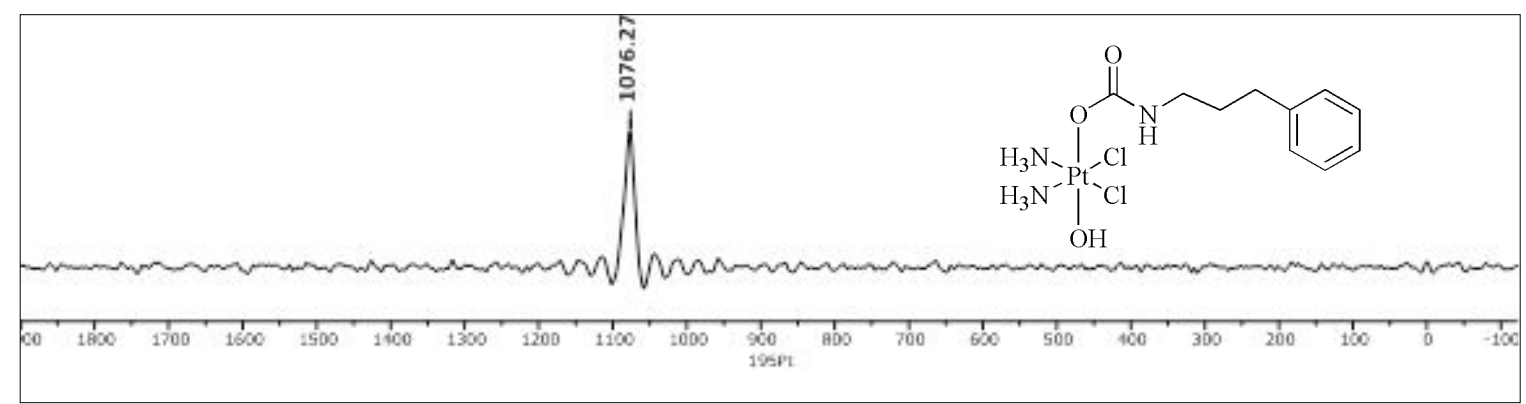

Figure S27 ${ }^{195} \mathrm{Pt}$ NMR of 2 in DMSO- $d_{6}$. 


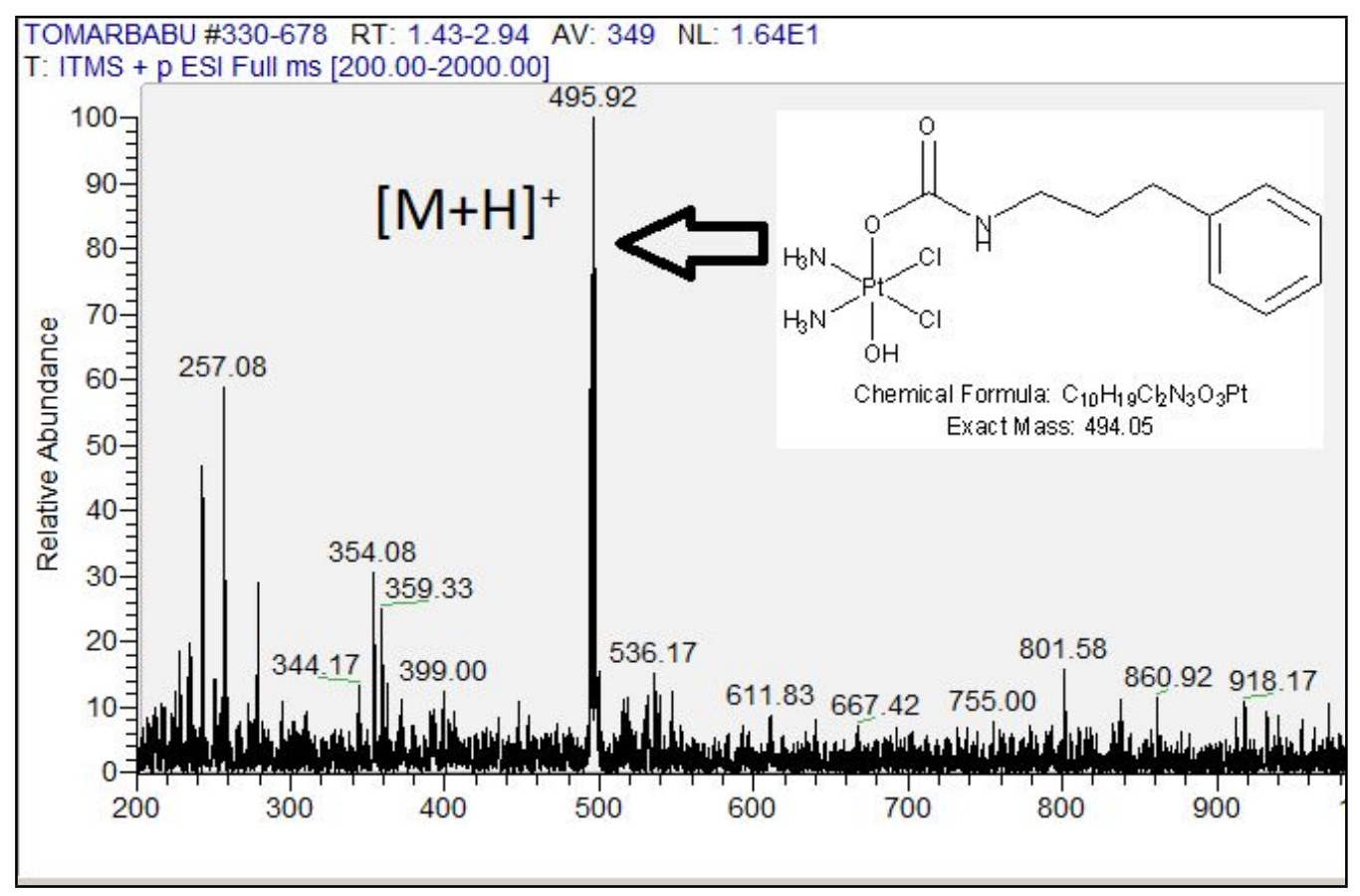

Figure S28 ESI-MS (+ve) data of 2.

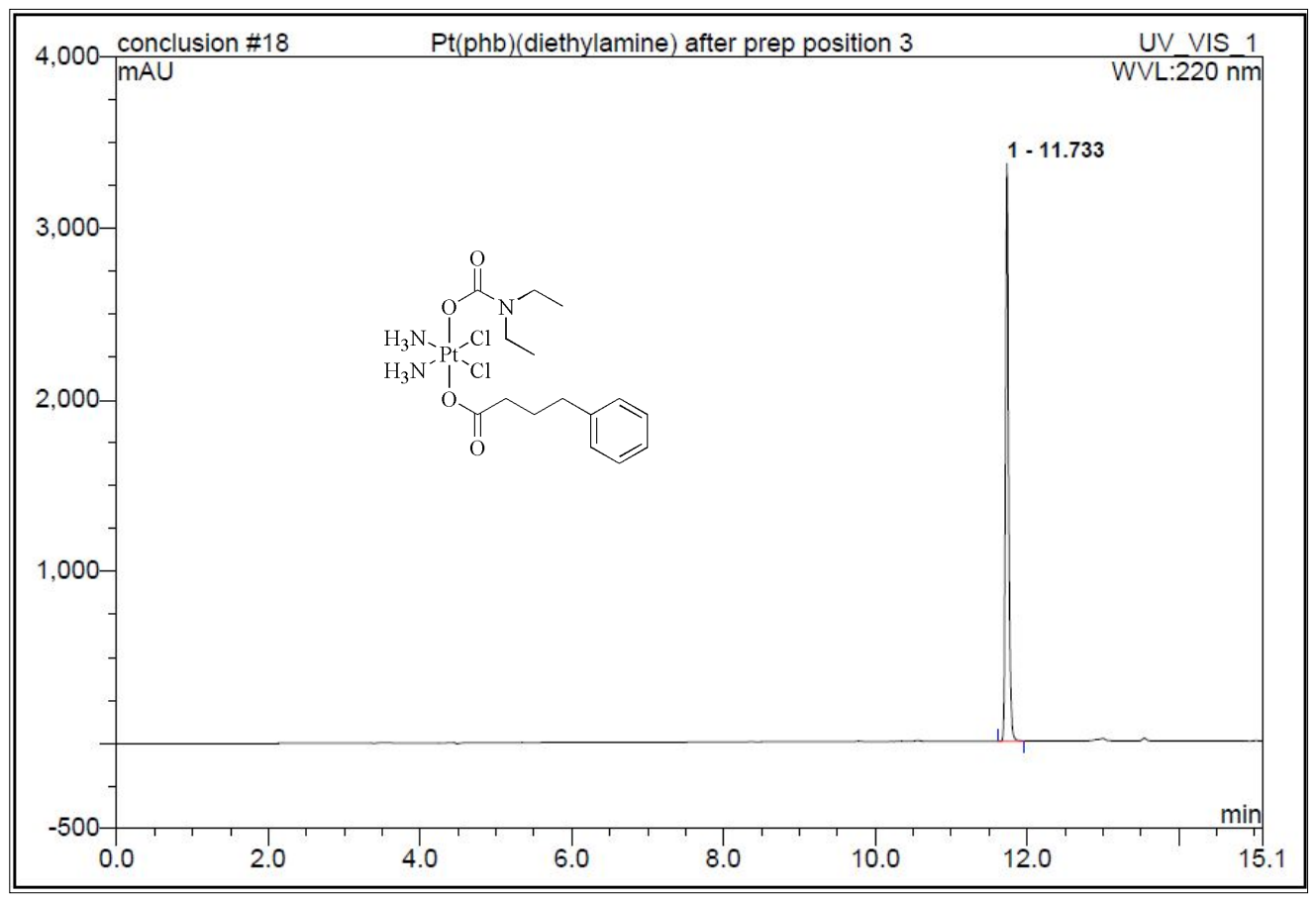

Figure S29 HPLC chromatogram of 3 ran with $0-100 \%$ linear gradient acetonitrile gradient in water over 15 min. 


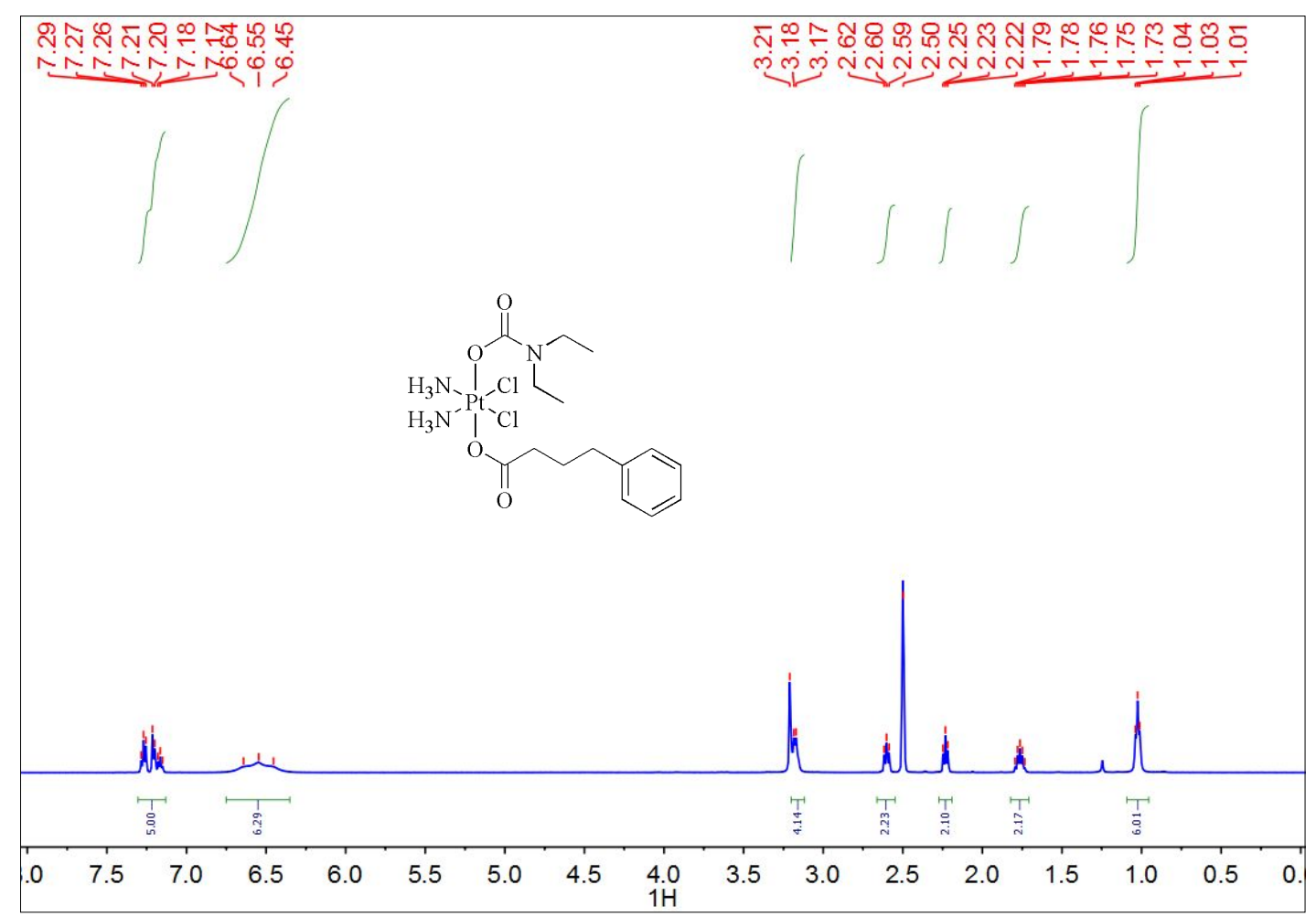

Figure S30 ${ }^{1} \mathrm{H}$ NMR of 3 in DMSO- $d_{6}$.

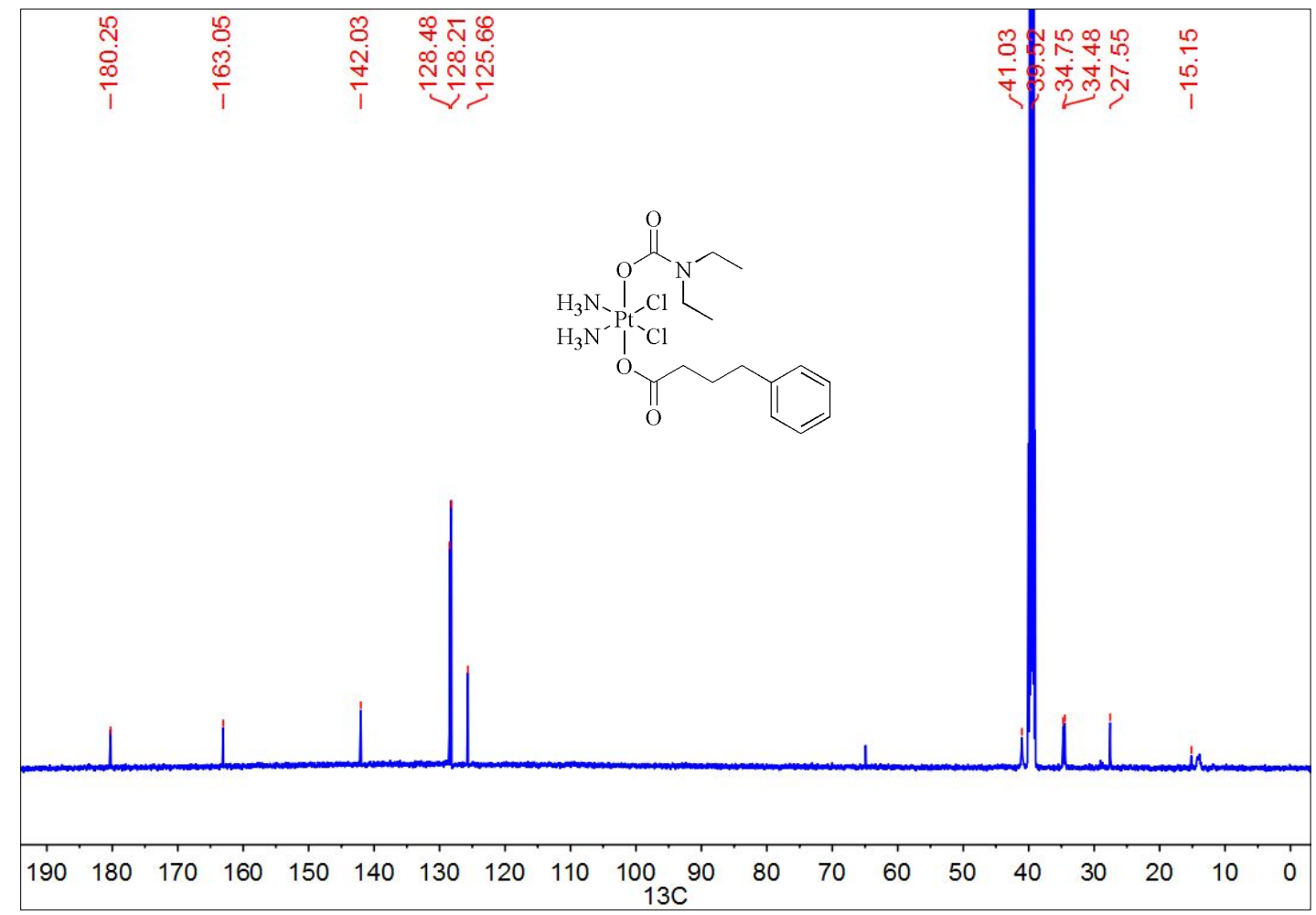

Figure S31 ${ }^{13}$ C NMR of 3 in DMSO- $d_{6}$. 




Figure S32 ${ }^{195} \mathrm{Pt}$ NMR of 3 in DMSO- $d_{6}$.

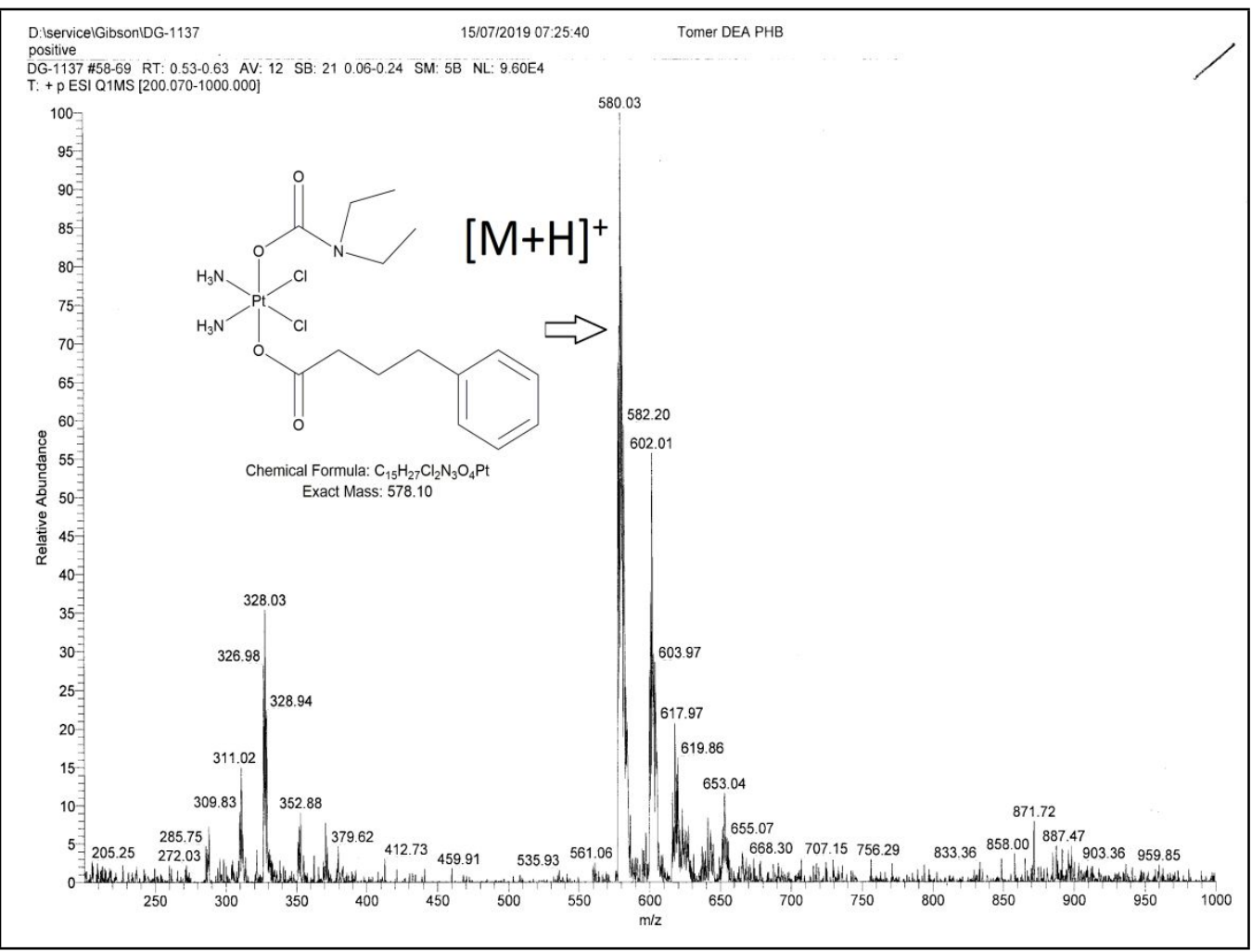

Figure S33 ESI-MS (+ve) data of 3. 


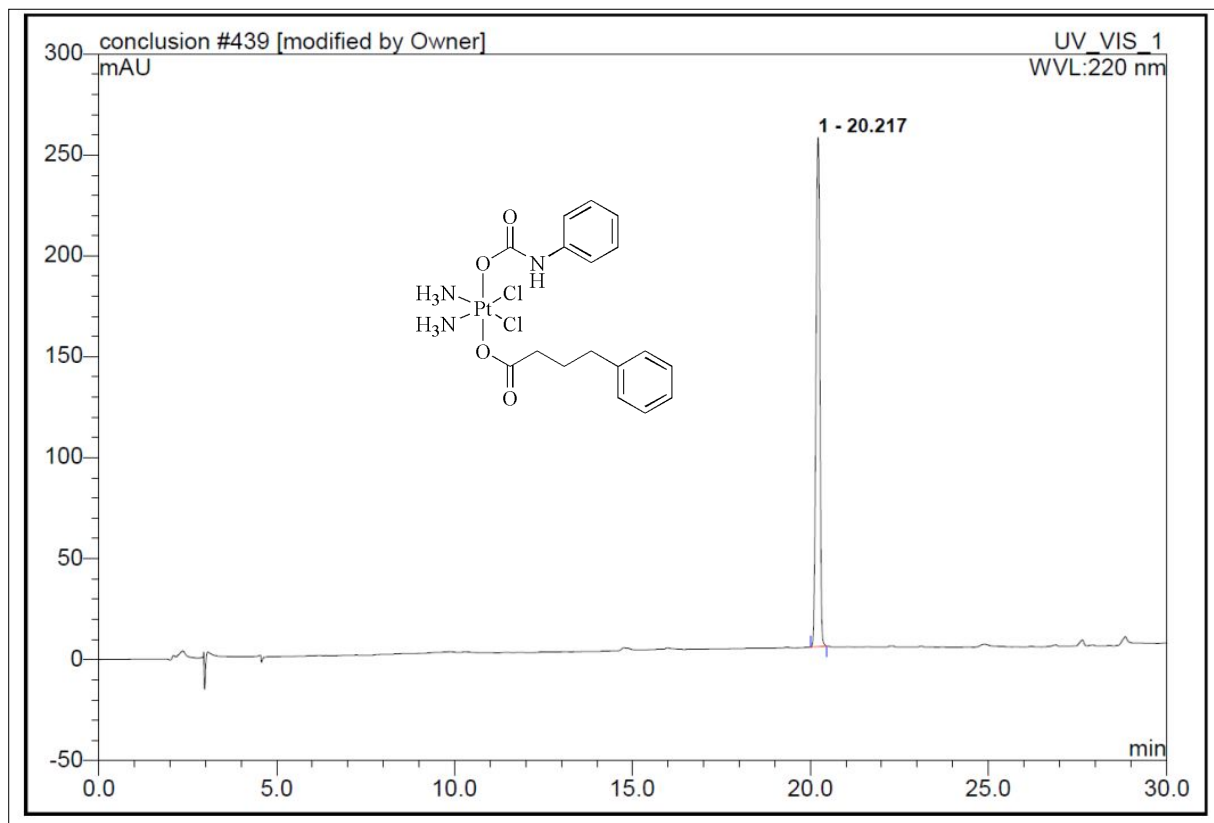

\begin{tabular}{|c|cccrccc|}
\hline No. & $\begin{array}{c}\text { Ret.Time } \\
\text { min }\end{array}$ & Peak Name & $\begin{array}{c}\text { Height } \\
\text { mAU }\end{array}$ & $\begin{array}{c}\text { Area } \\
\text { mAU*min }\end{array}$ & $\begin{array}{c}\text { Rel.Area } \\
\%\end{array}$ & Amount & Type \\
\hline 1 & 20.22 & n.a. & 252.151 & 31.598 & 100.00 & n.a. & BMB $^{*}$ \\
\hline Total: & & & 252.151 & 31.598 & 100.00 & 0.000 & \\
\hline
\end{tabular}

Figure S34 HPLC chromatogram of 4 ran with $0-90 \%$ linear gradient of acetonitrile gradient in water over $\mathbf{3 0}$ min.

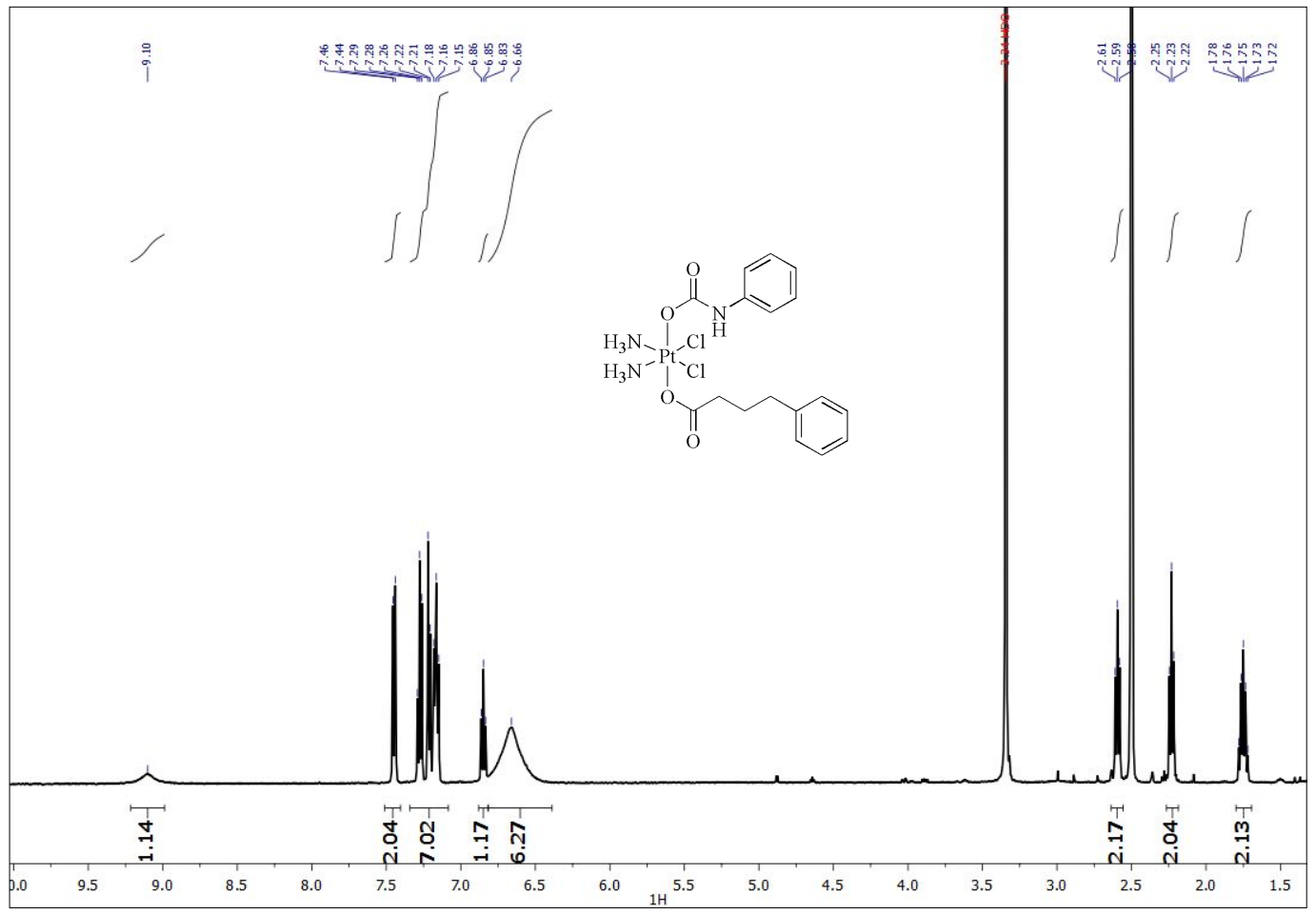

Figure S35 ${ }^{1}$ H NMR of 4 in DMSO- $d_{6}$. 


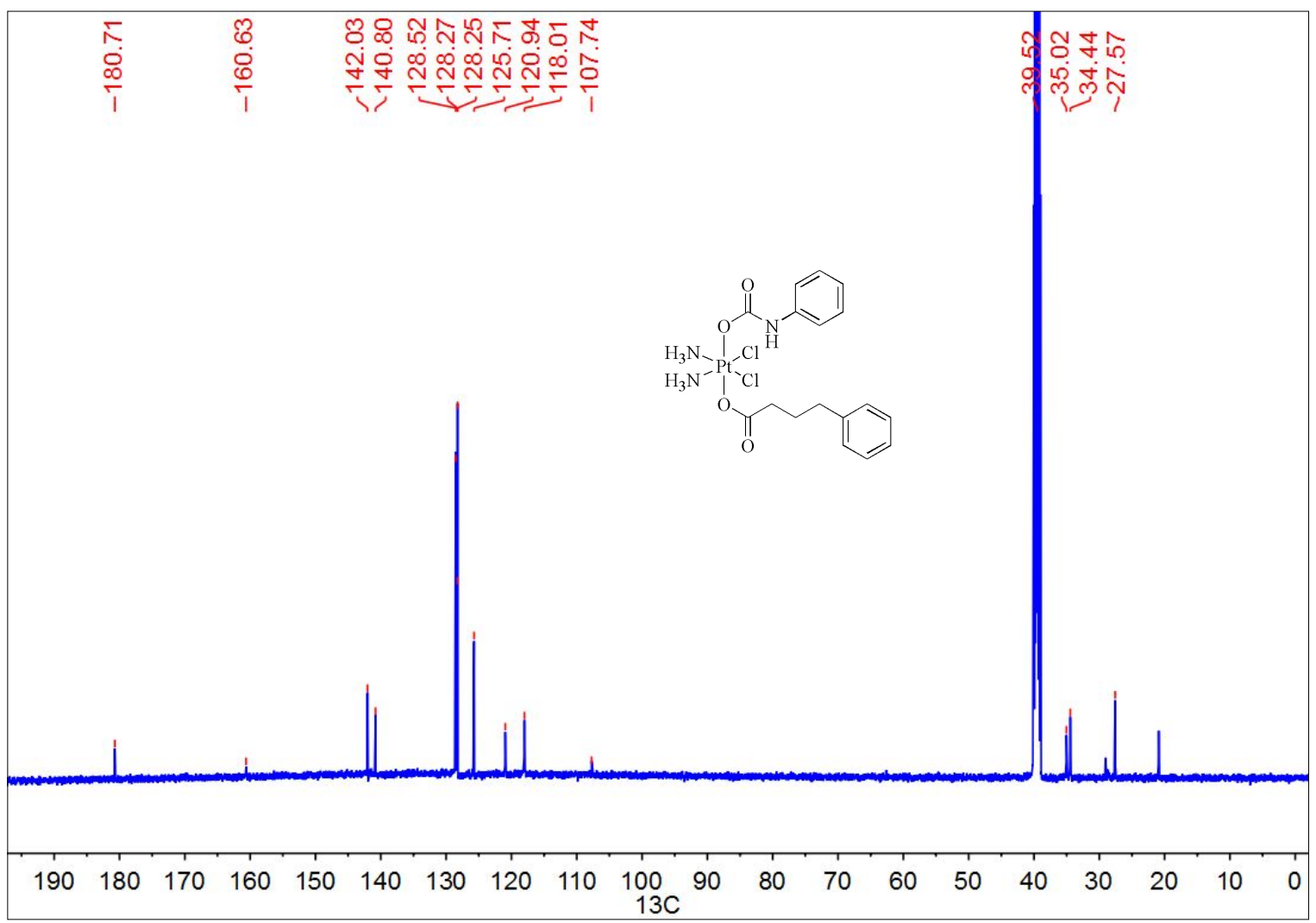

Figure S36 ${ }^{13} \mathrm{C}$ NMR of 4 in DMSO- $d_{6}$.

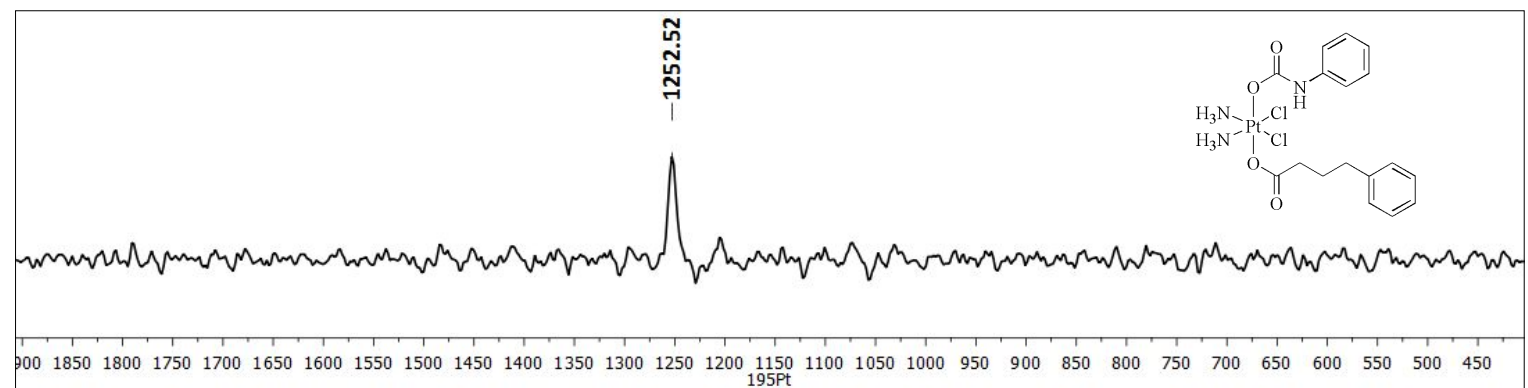

Figure S37 ${ }^{195} \mathrm{Pt}$ NMR of 4 in DMSO- $d_{6}$. 


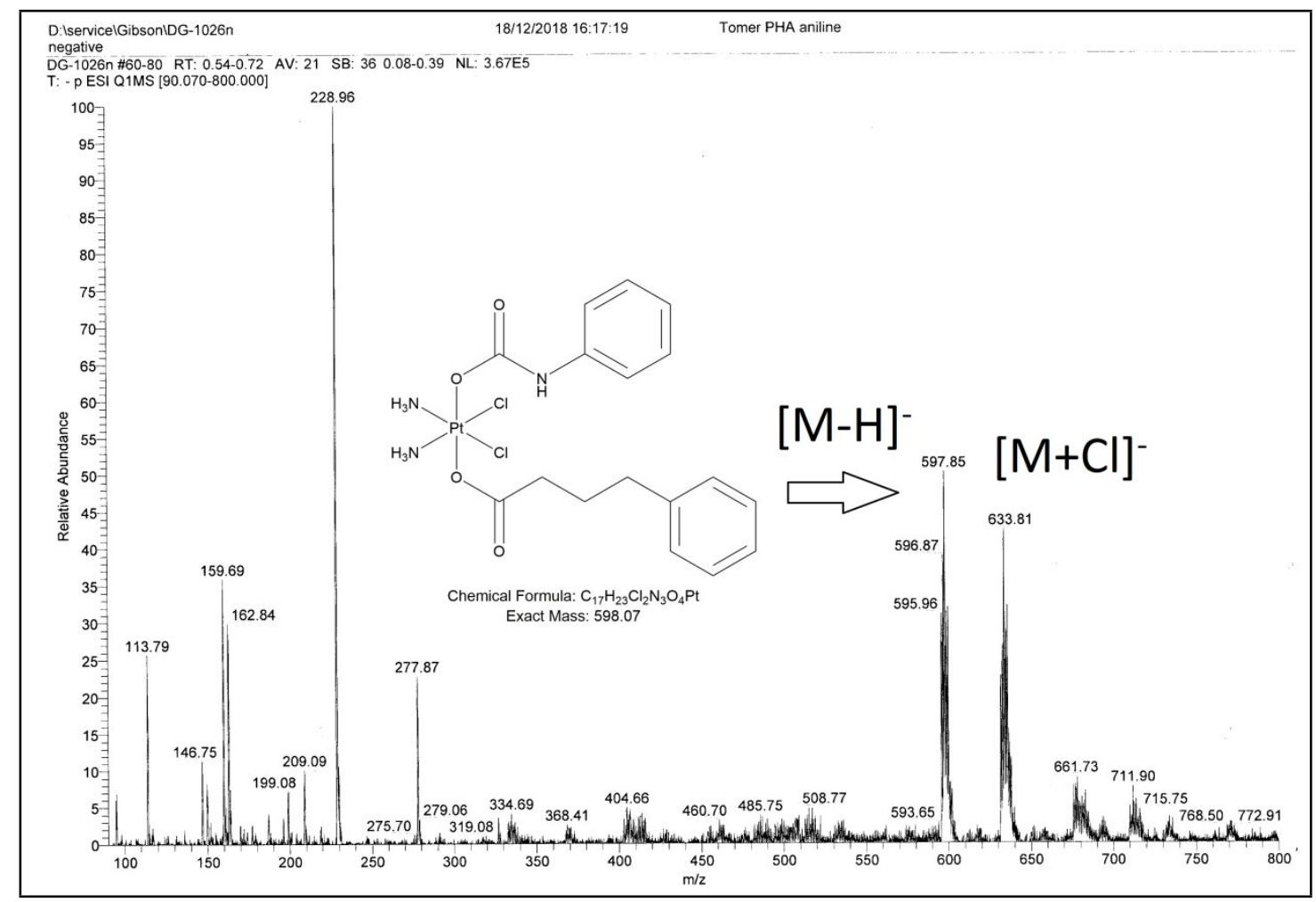

Figure S38 ESI-MS (-ve) data of 4.

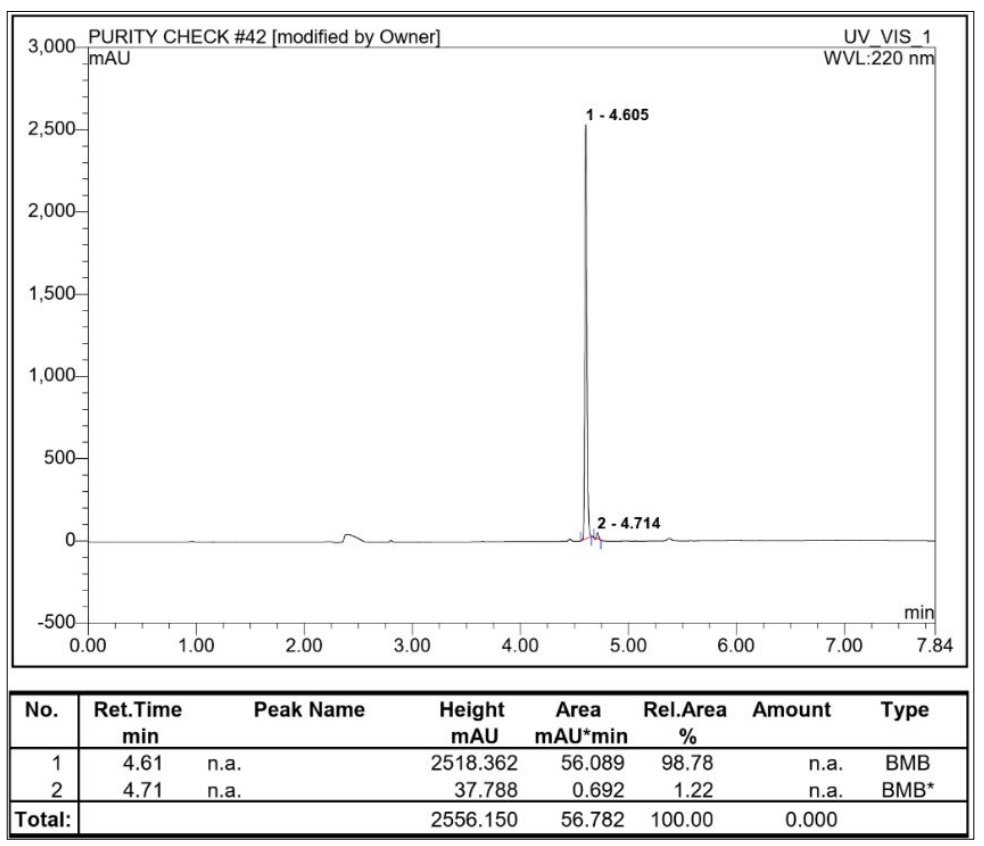

Figure S39 HPLC chromatogram of 5 ran with 0-100\% acetonitrile in 5.84 min then 3 min constant at $100 \%$ acetonitrile. 


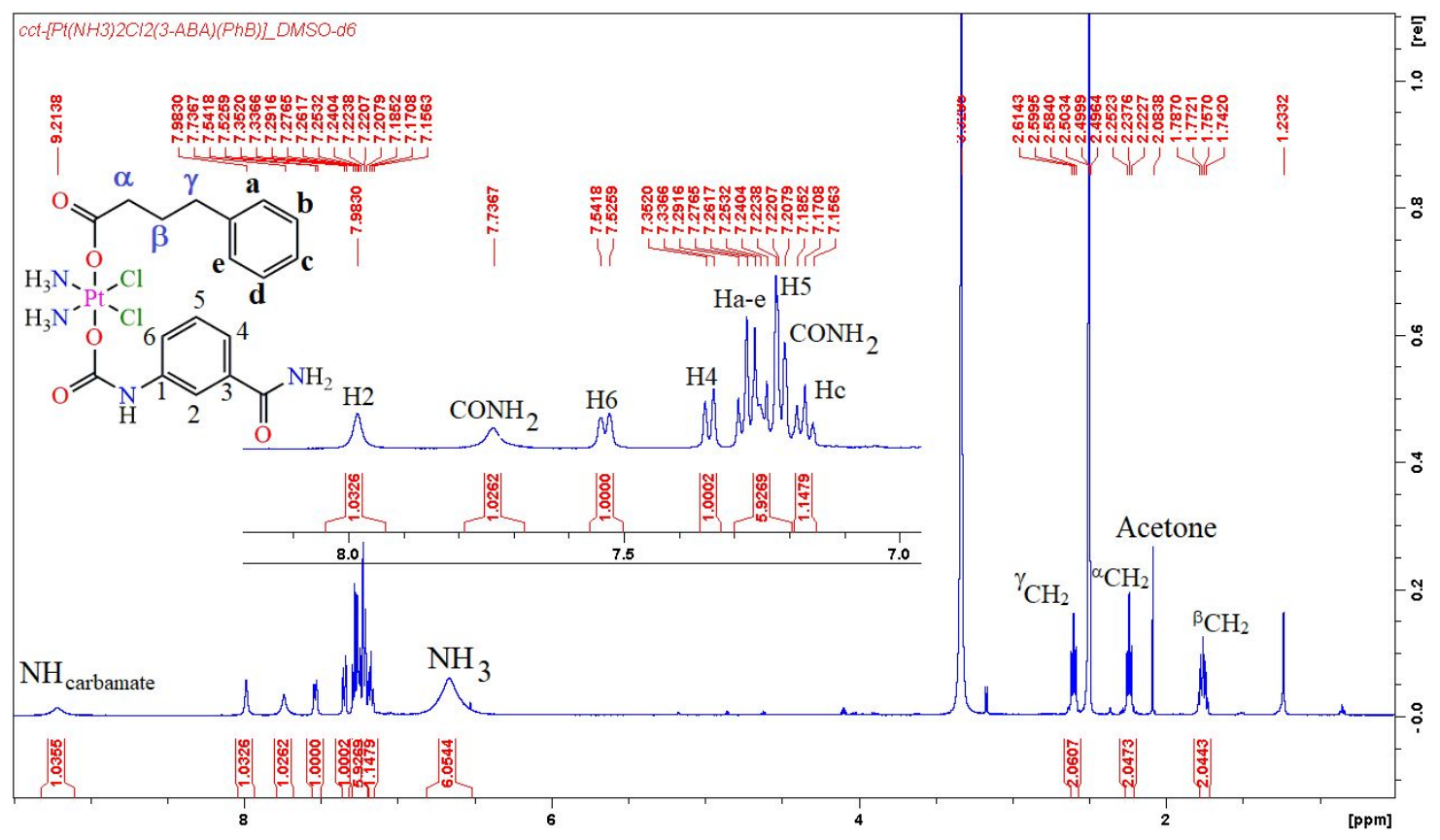

Figure S40 ${ }^{1} \mathrm{H}$ NMR of 5 in DMSO- $d_{6}$.

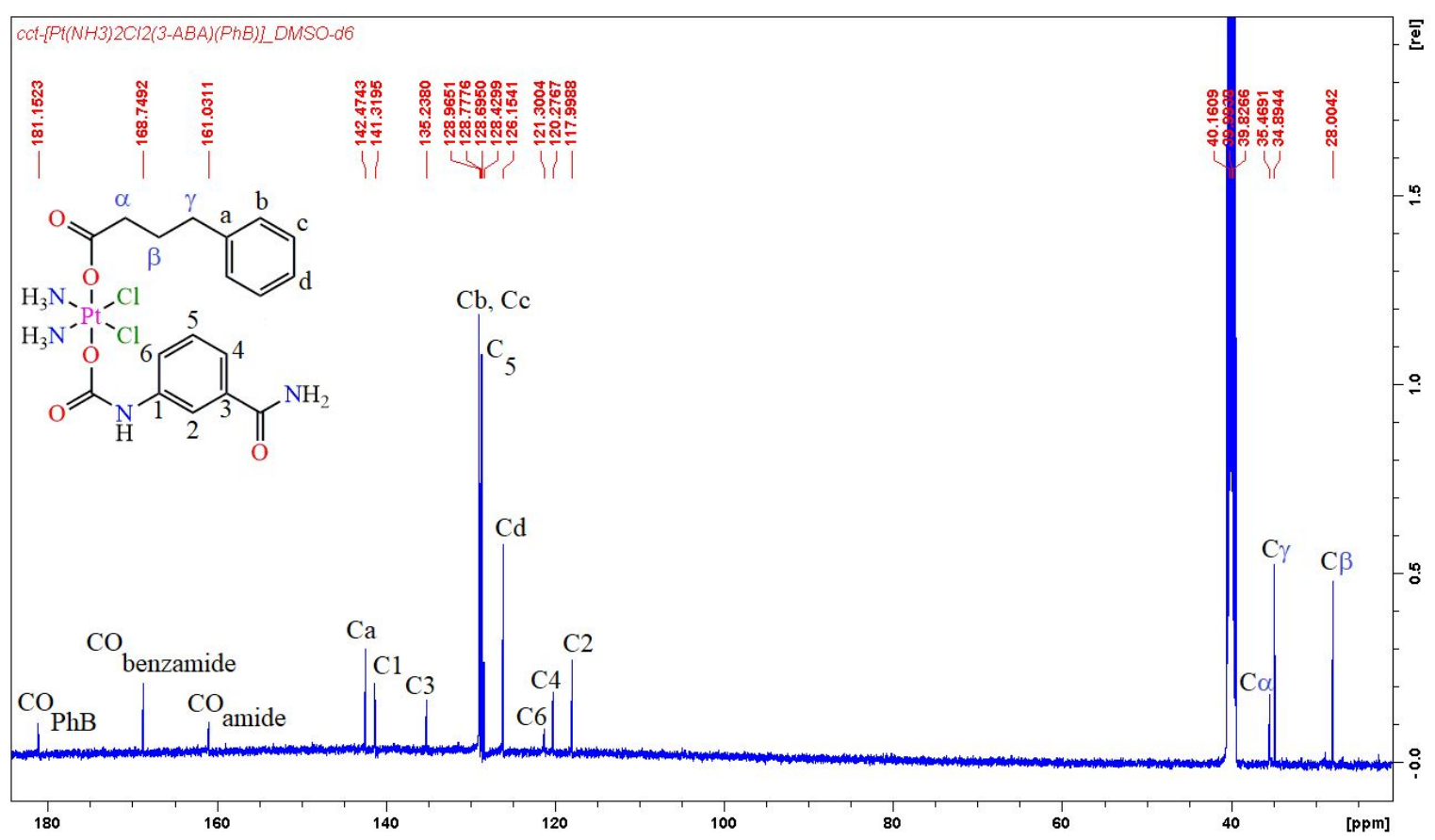

Figure S41 ${ }^{13}$ C NMR of 5 in DMSO- $d_{6}$. 


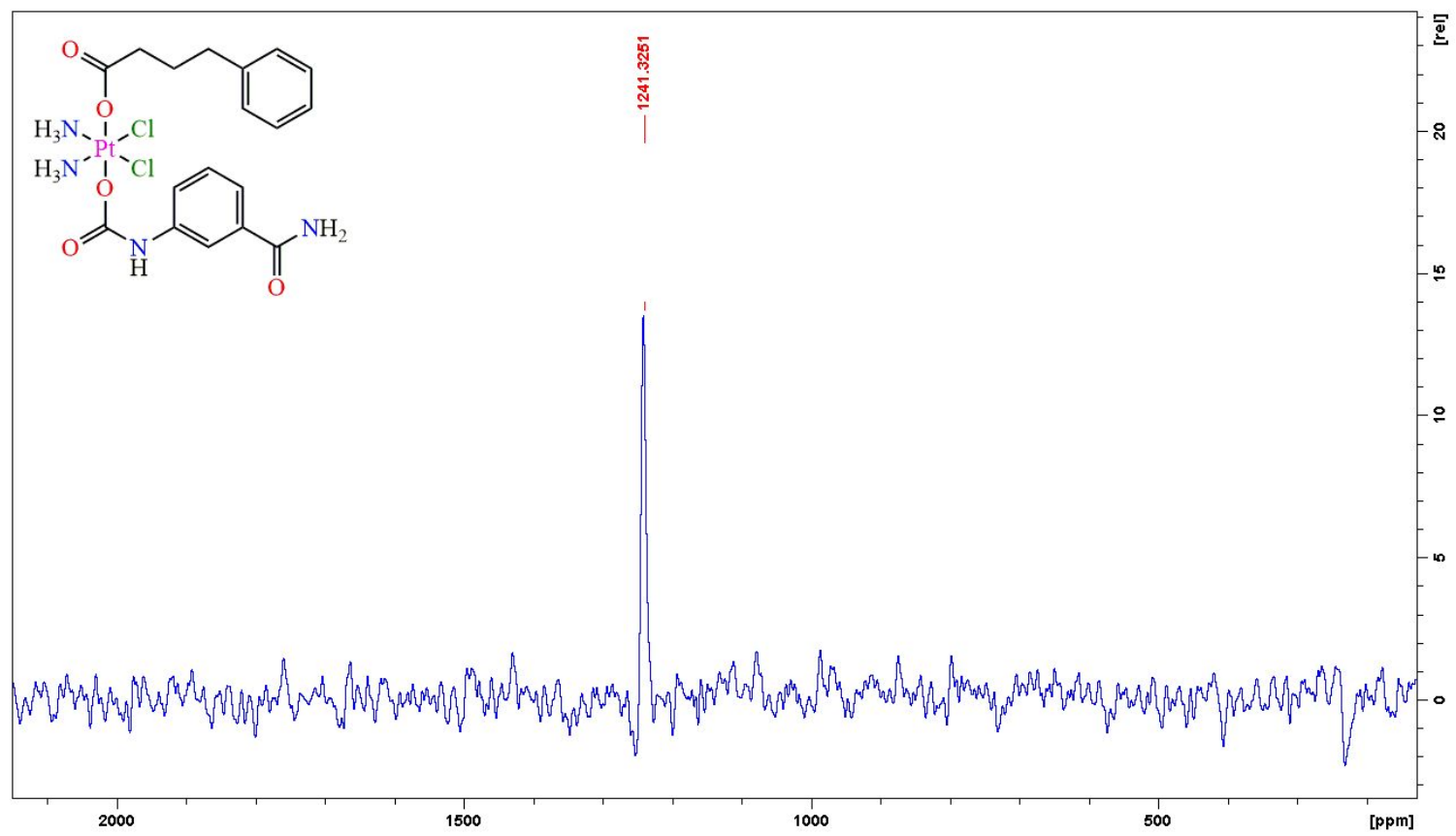

Figure S42 ${ }^{195} \mathrm{Pt}$ NMR of 5 in DMSO- $\boldsymbol{d}_{\boldsymbol{6}}$.

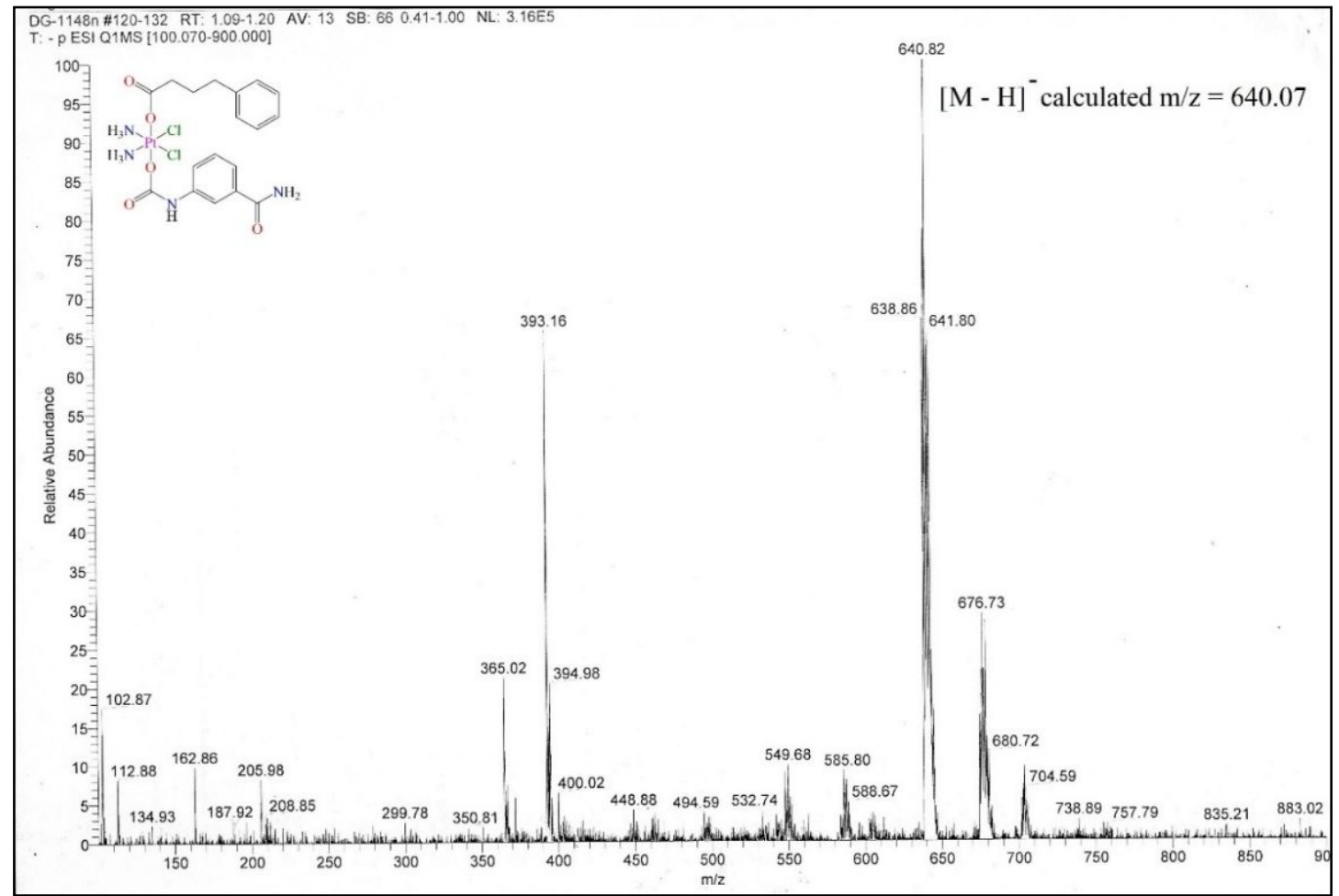

Figure S43 ESI-MS (-ve) data of 5. 


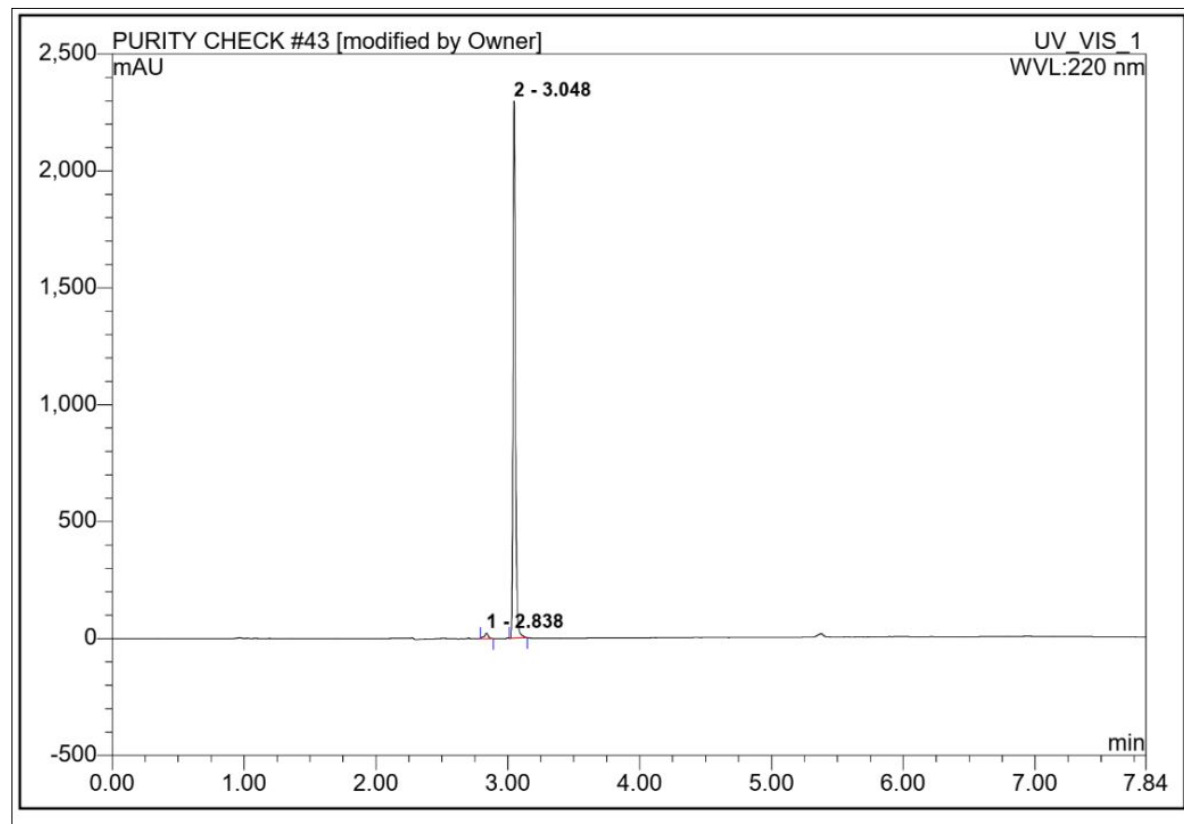

\begin{tabular}{|r|ccrrrrr||}
\hline No. & $\begin{array}{c}\text { Ret.Time } \\
\text { min }\end{array}$ & Peak Name & $\begin{array}{c}\text { Height } \\
\text { mAU }\end{array}$ & $\begin{array}{r}\text { Area } \\
\text { mAU*min }\end{array}$ & $\begin{array}{r}\text { Rel.Area } \\
\%\end{array}$ & Amount & Type \\
\hline 1 & 2.84 & n.a. & 22.930 & 0.784 & 1.61 & n.a. & BMB $^{*}$ \\
2 & 3.05 & n.a. & 2297.086 & 48.026 & 98.39 & n.a. & BMB $^{*}$ \\
\hline Total: & & & 2320.016 & 48.810 & 100.00 & 0.000 & \\
\hline
\end{tabular}

Figure S44 HPLC chromatogram of 6 ran with 0-100\% acetonitrile in 5.84 min then 3 min constant at $100 \%$ acetonitrile.

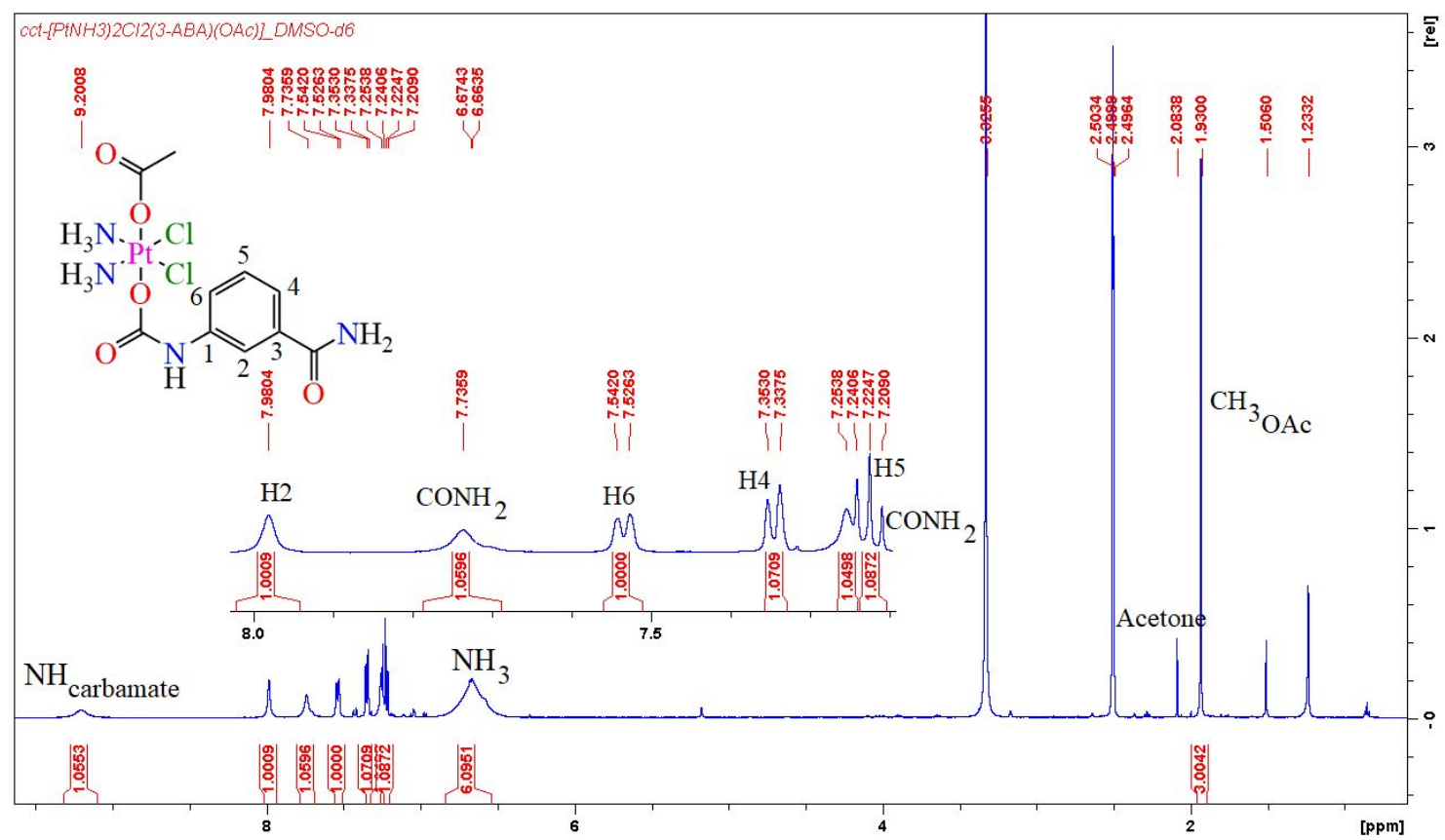

Figure S45 ${ }^{1}$ H NMR of 6 in DMSO- $d_{6}$. 


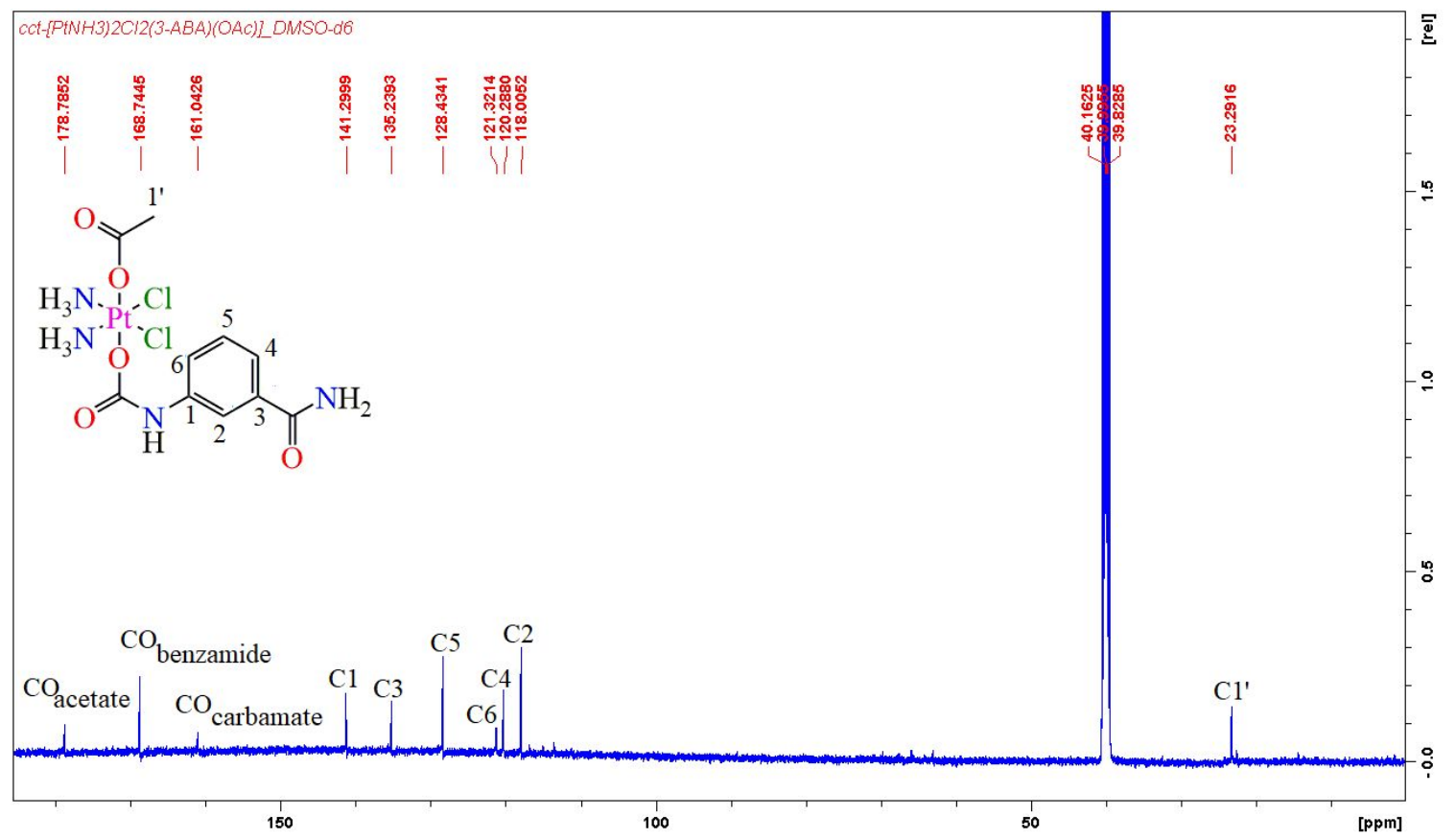

Figure S46 ${ }^{13}$ C NMR of 6 in DMSO- $d_{6}$.

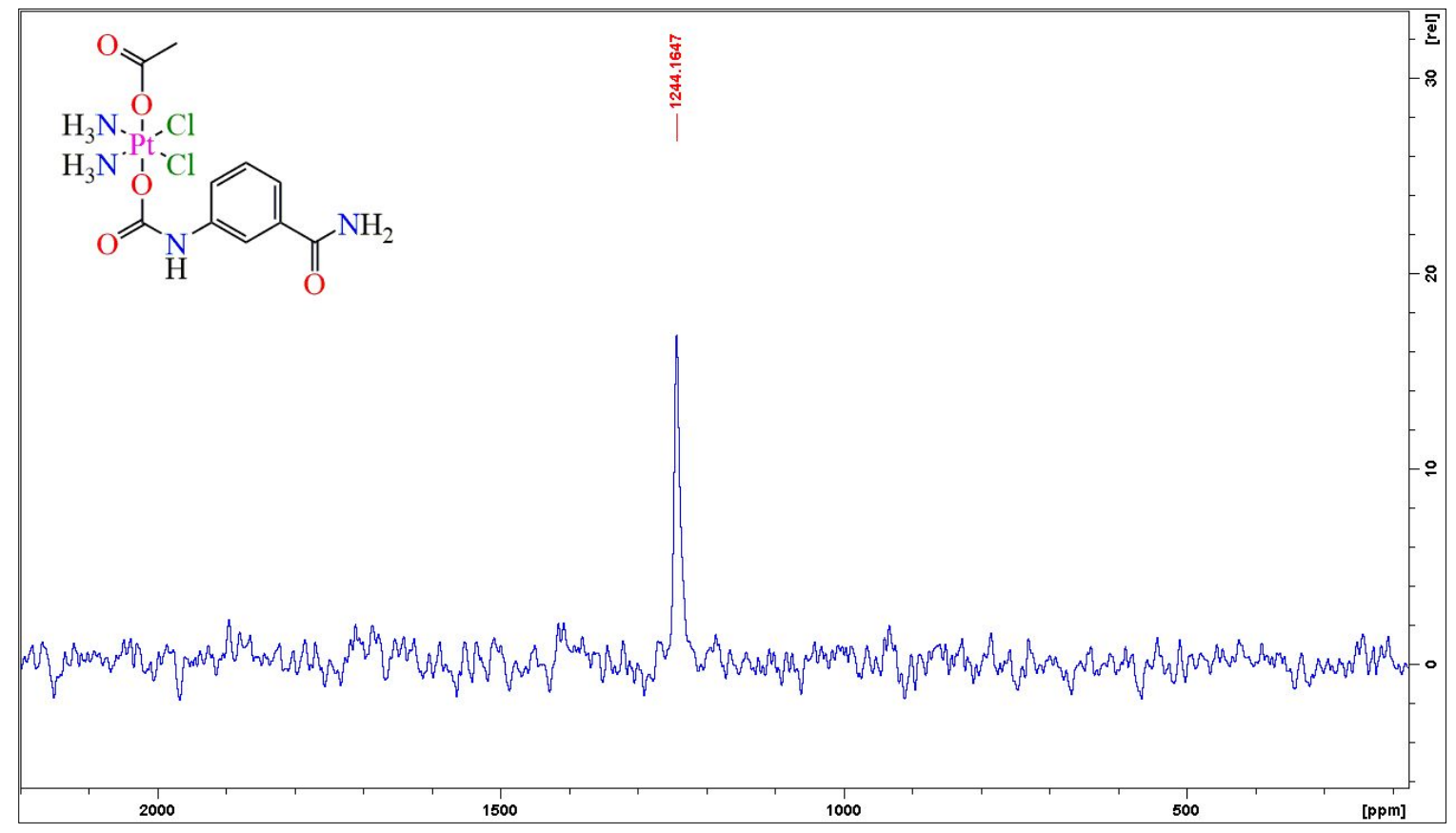

Figure S47 ${ }^{195} \mathrm{Pt}$ NMR of 6 in DMSO- $\boldsymbol{d}_{\mathbf{6}}$. 


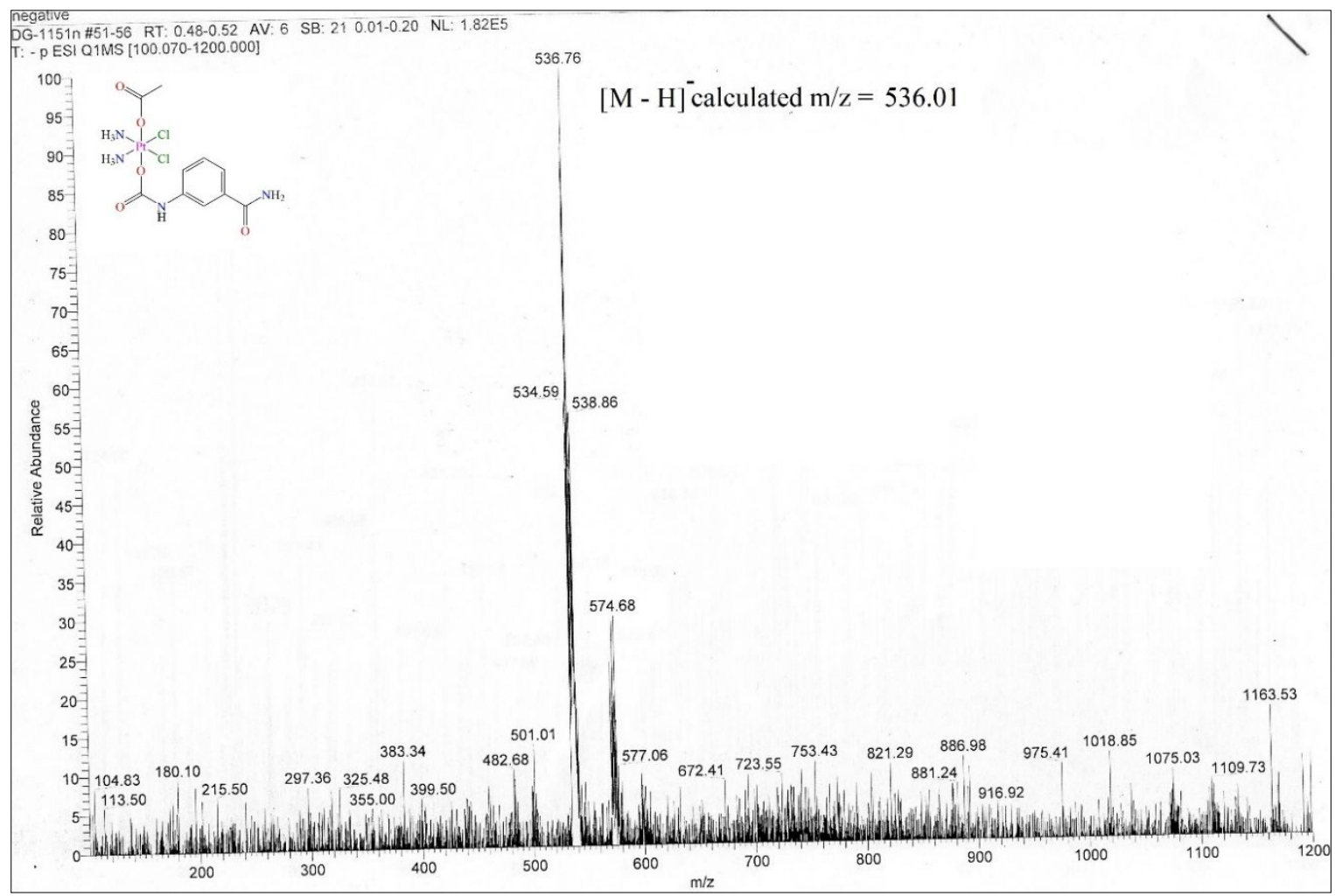

Figure S48 ESI-MS (-ve) data of 6.

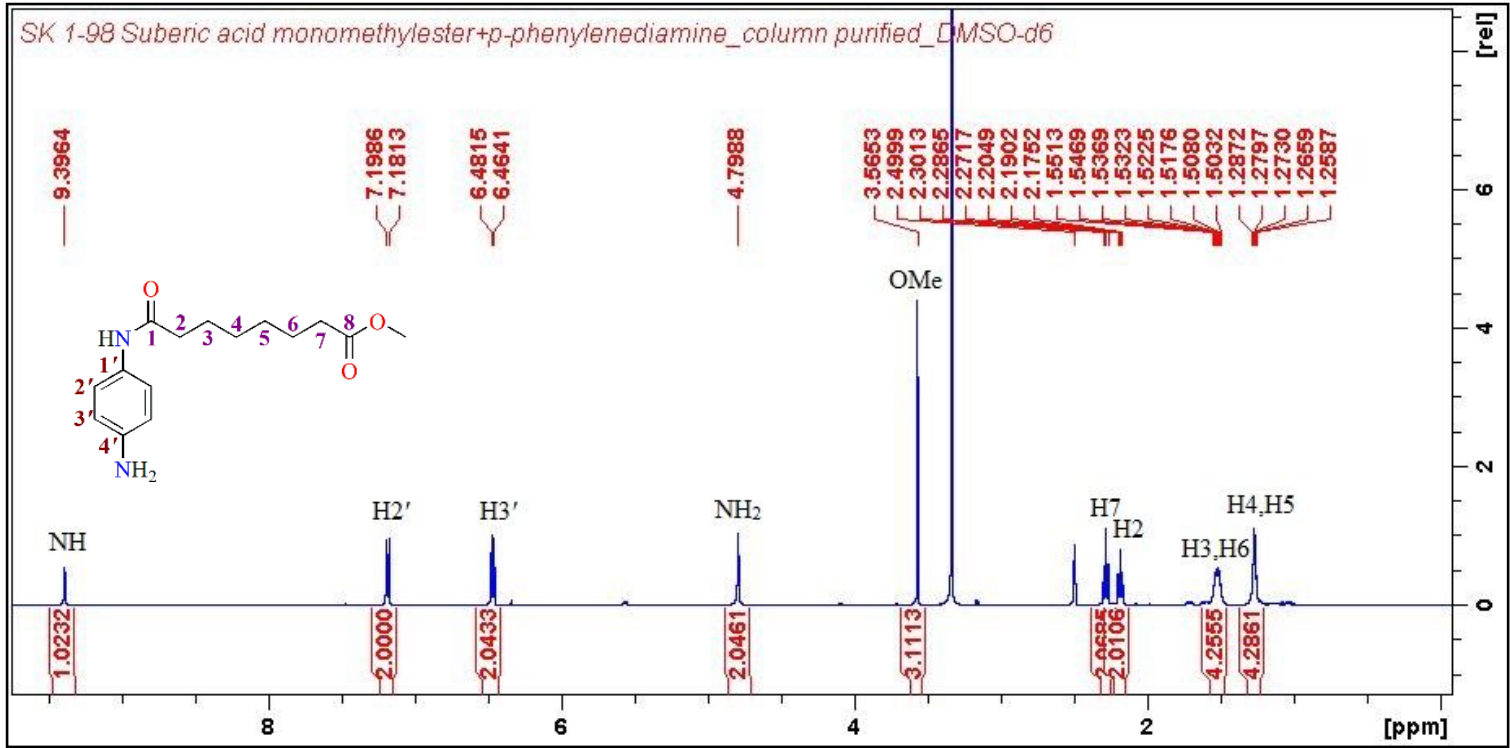

Figure S49 ${ }^{1} \mathrm{H}$ NMR of methyl 8-((4-aminophenyl)amino)-8-oxooctanoate in DMSO- $d_{6}$. 


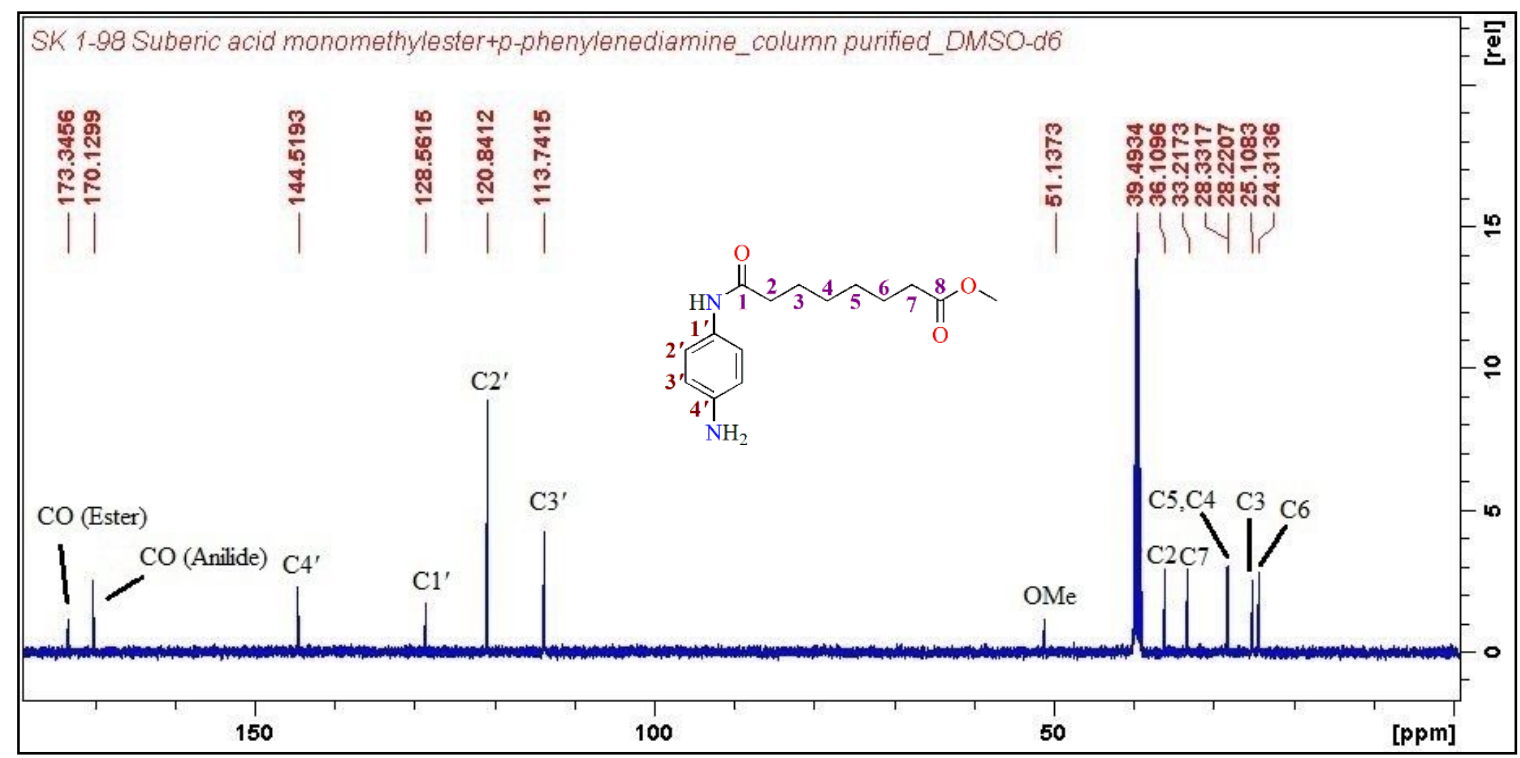

Figure S50 ${ }^{13} \mathrm{C}$ NMR of methyl 8-((4-aminophenyl)amino)-8-oxooctanoate in DMSO- $d_{6}$.

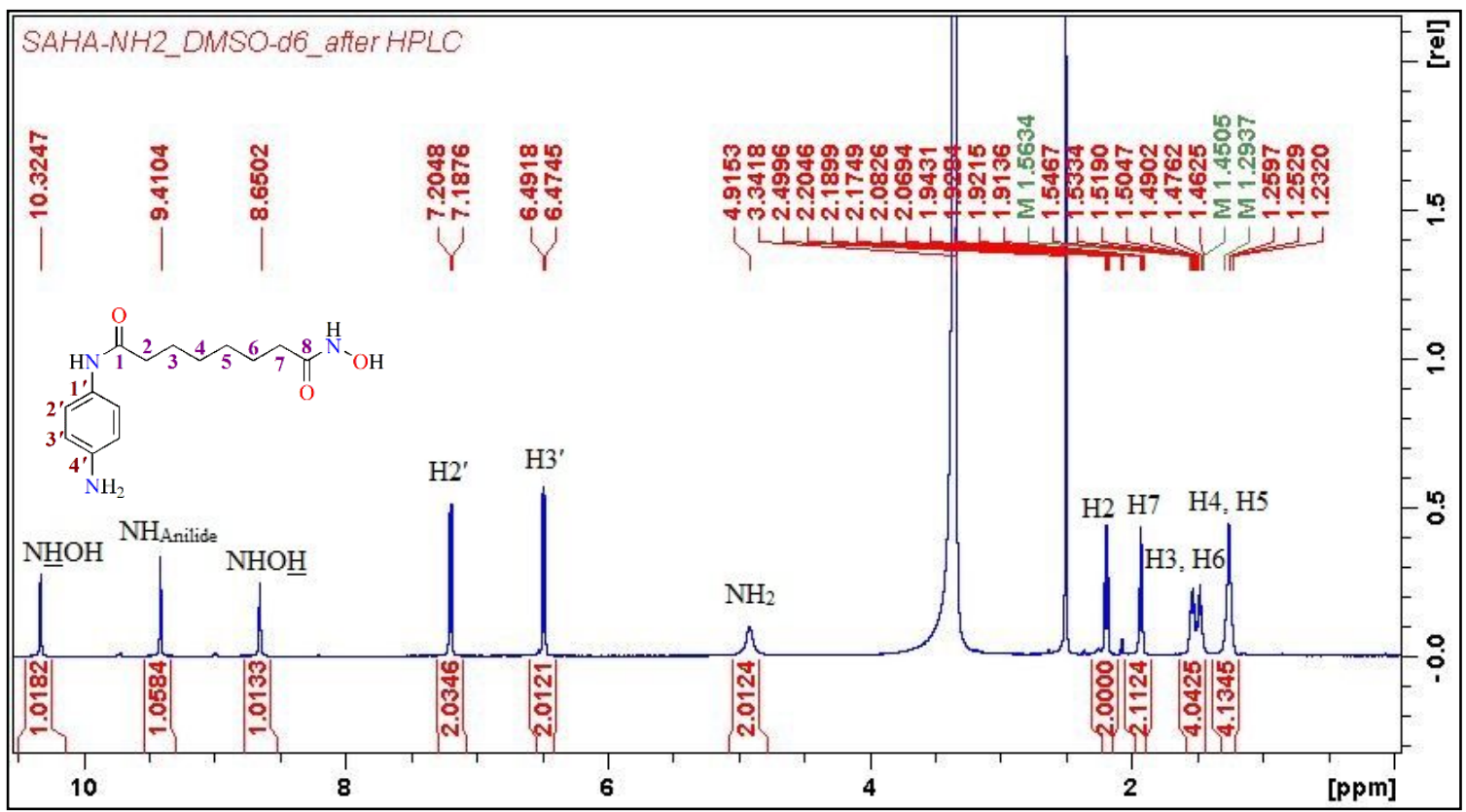

Figure S51 ${ }^{1} \mathrm{H}$ NMR of SAHA-NH ${ }_{2}$ in DMSO- $d_{6}$. 


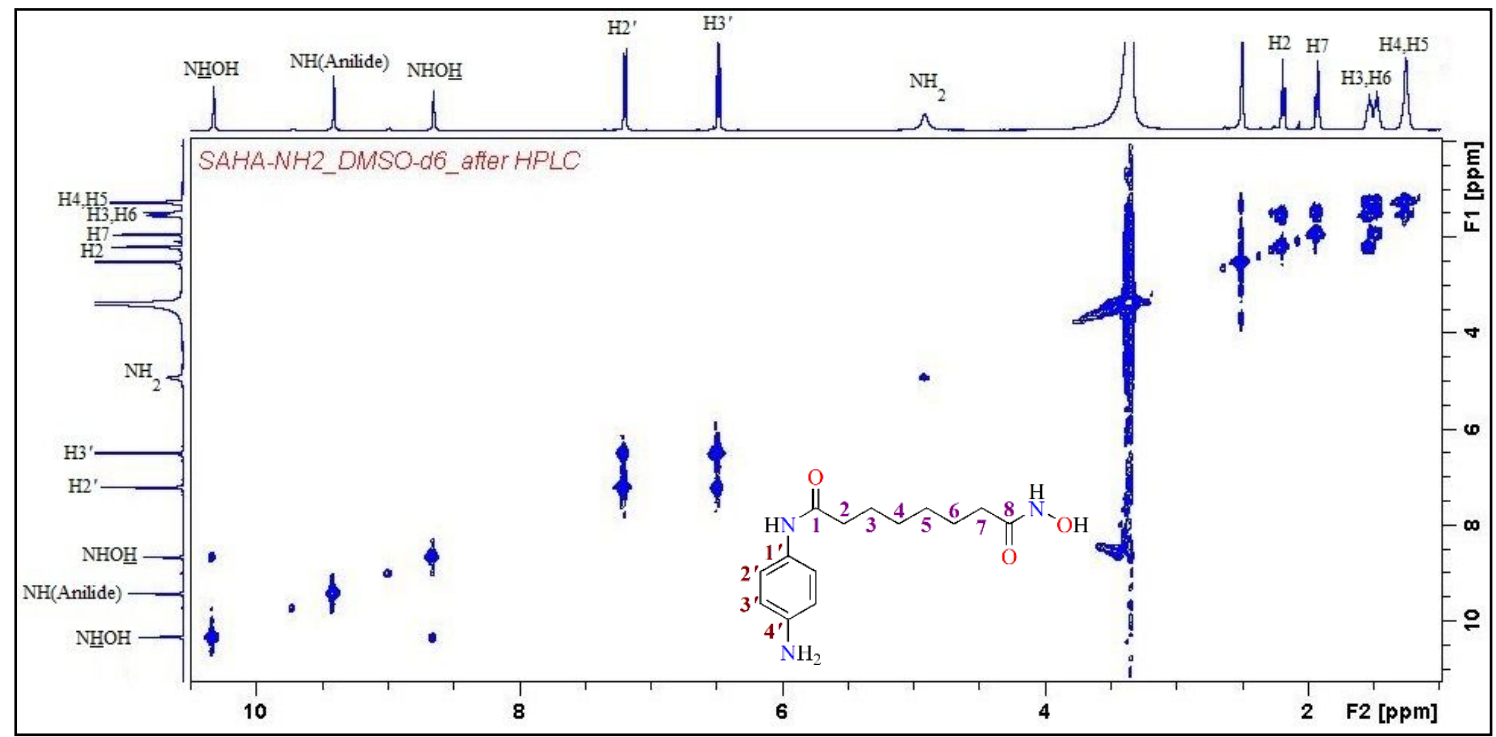

Figure S52 COSY NMR of SAHA-NH $\mathrm{NH}_{2}$ in DMS- $d_{6}$.

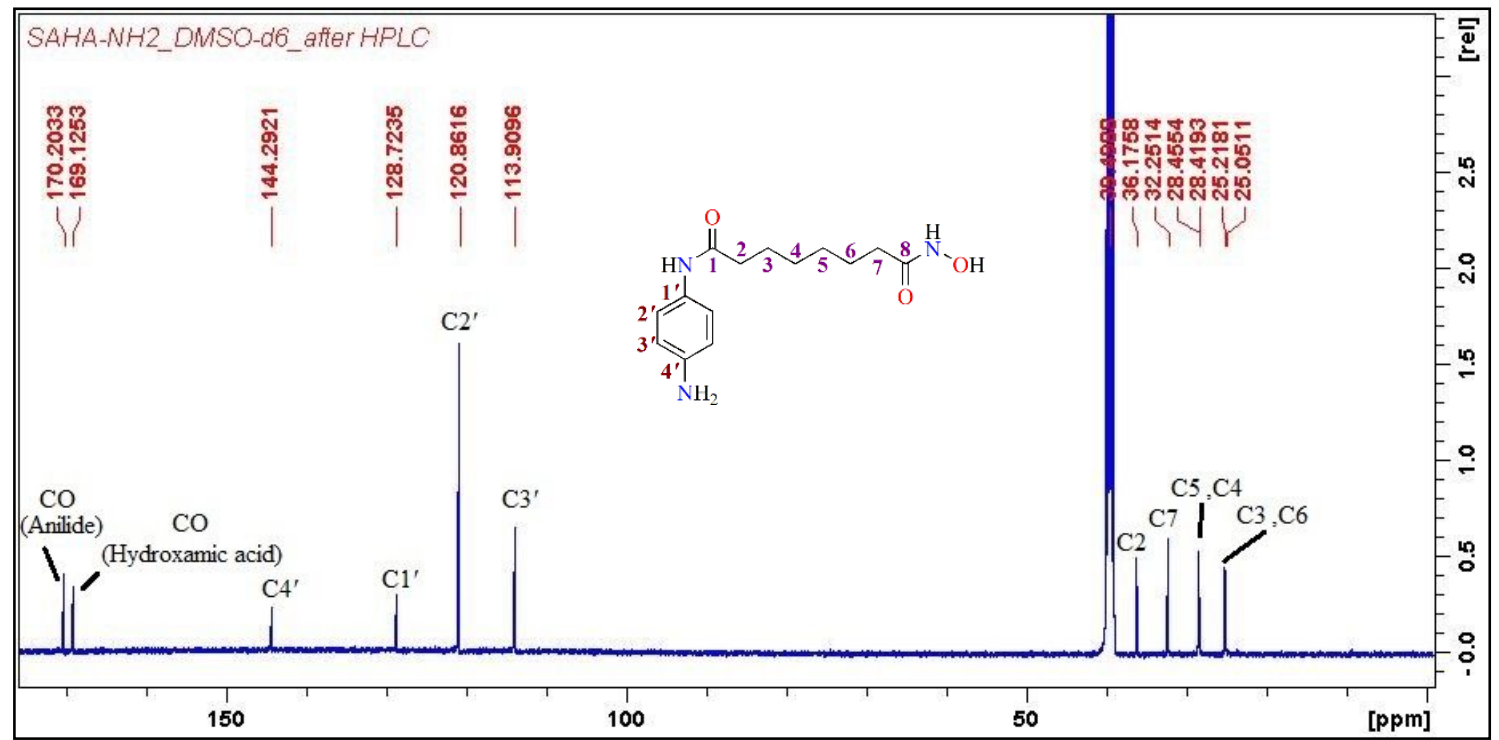

Figure S53 ${ }^{13} \mathrm{C}$ NMR of SAHA-NH$H_{2}$ in DMSO- $d_{6}$. 


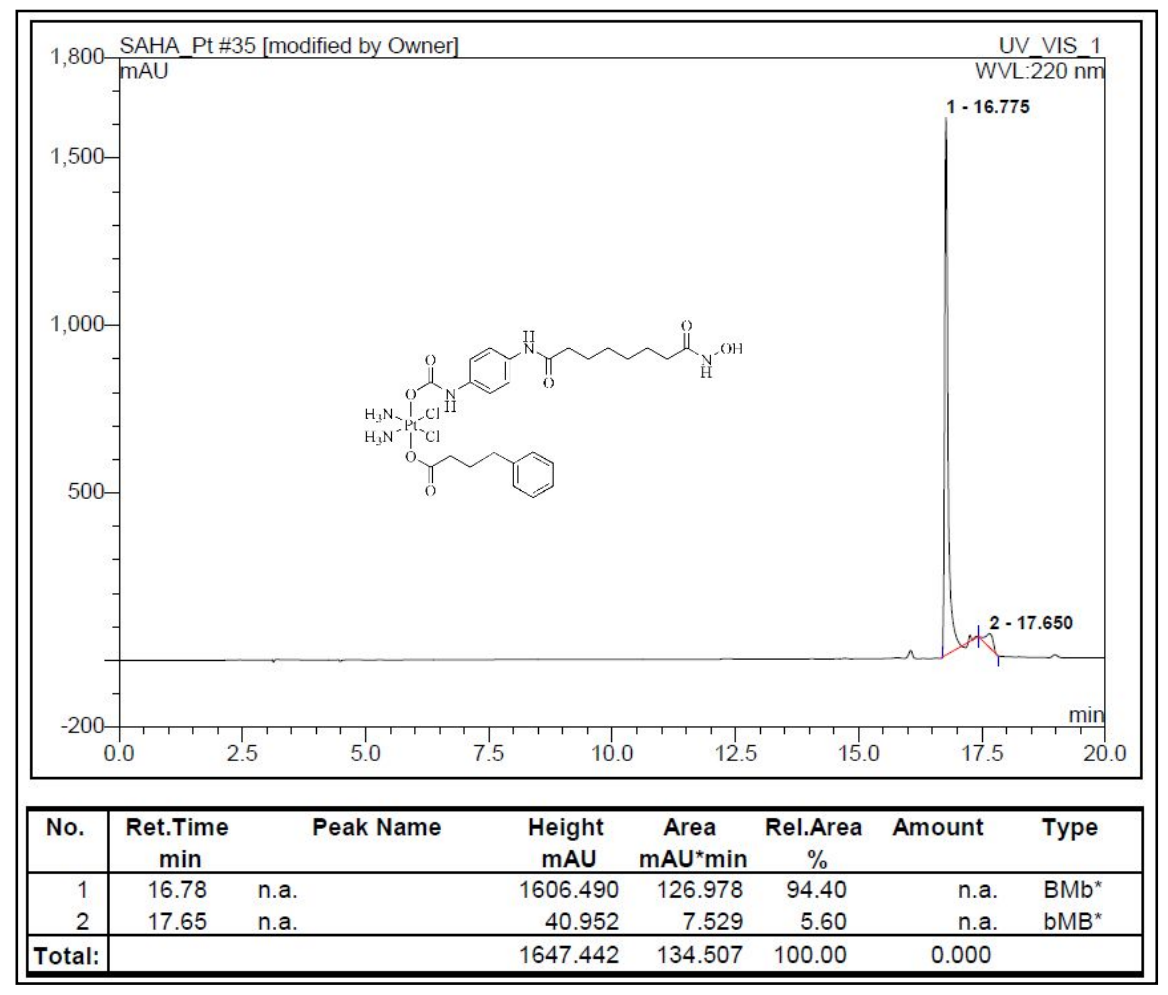

Figure S54 HPLC chromatogram of 7 ran in $(0-60 \%)$ acetonitrile gradient in water over $20 \mathrm{~min}$.

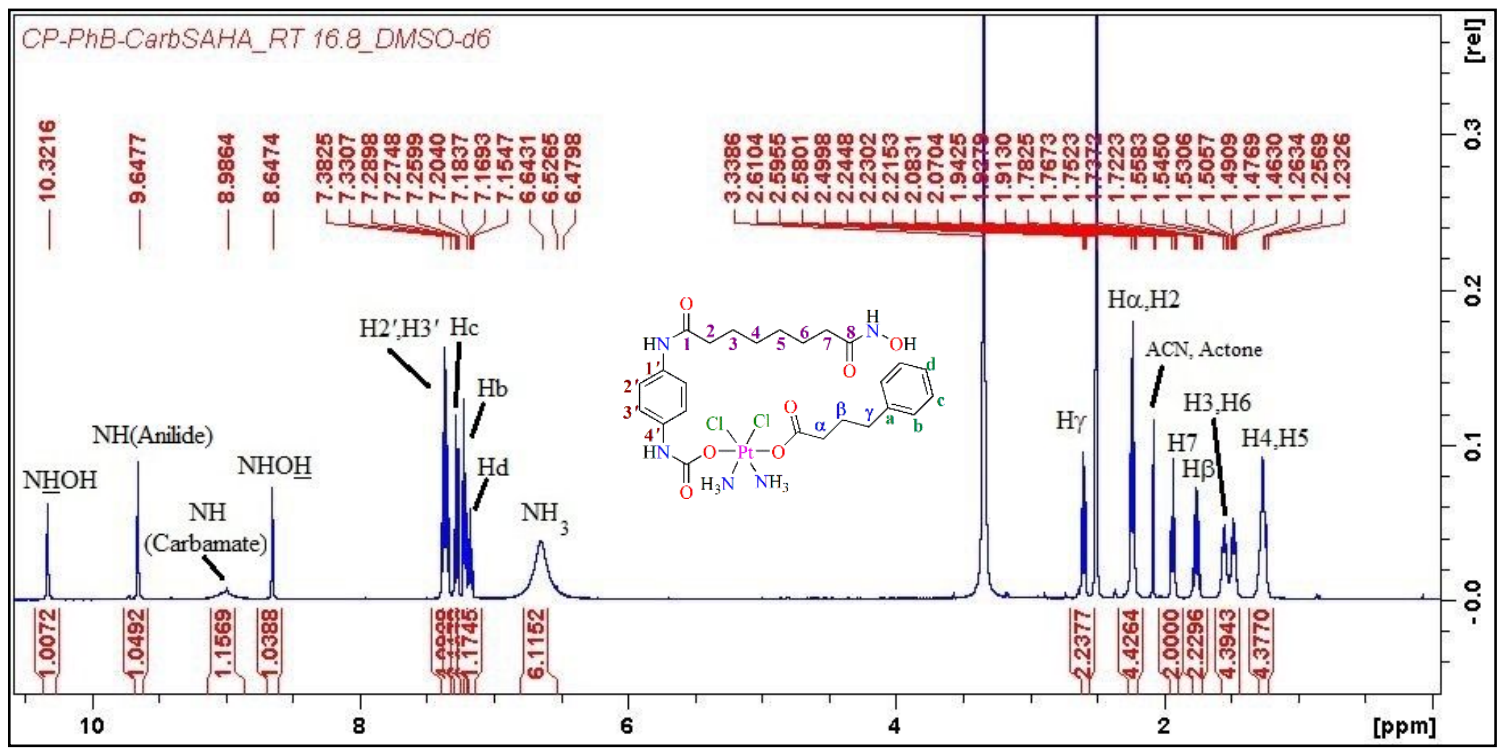

Figure S55 ${ }^{1} \mathrm{H}$ NMR of 7 in DMSO- $d_{6}$. 


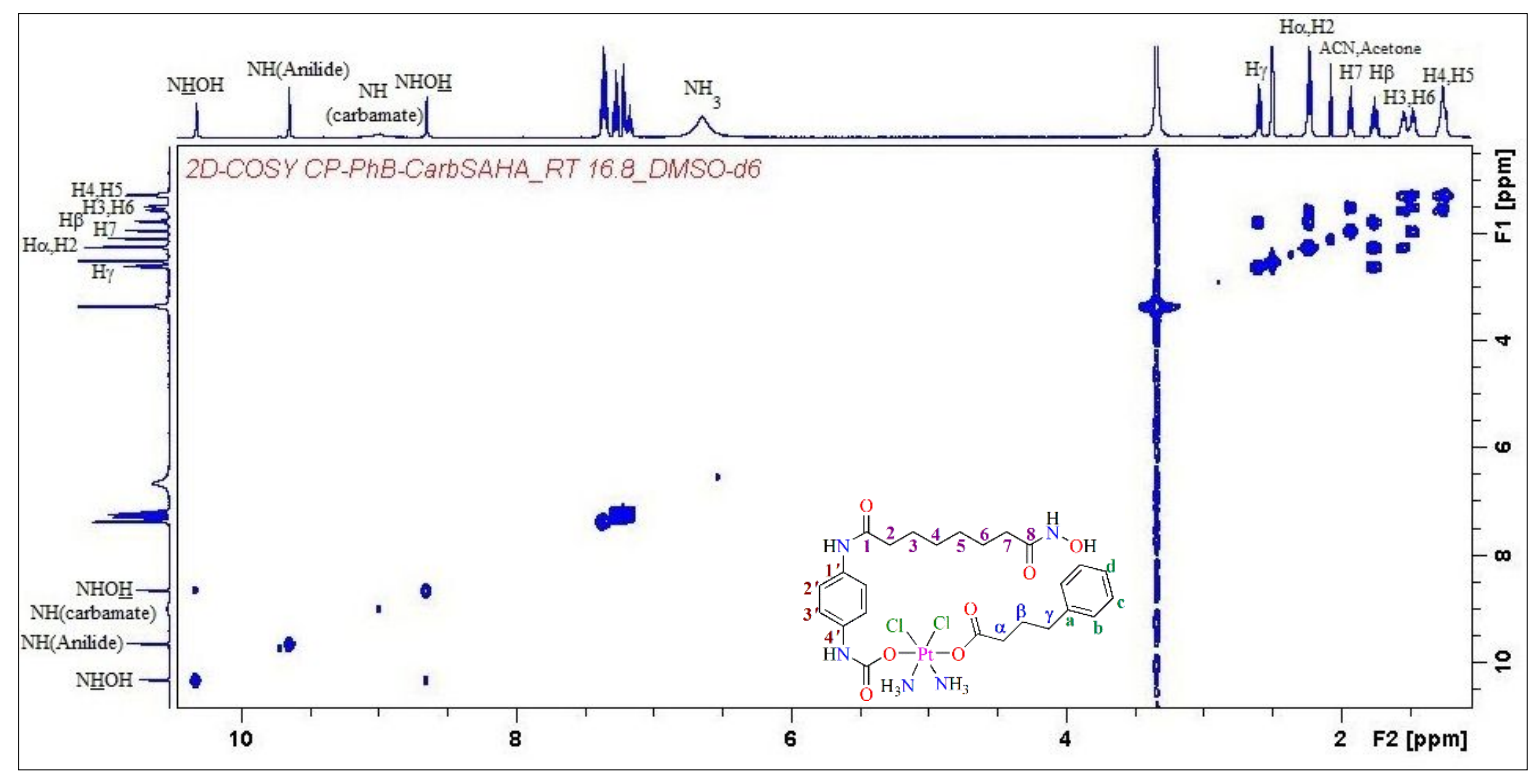

Figure S56 COSY NMR of 7 in DMSO- $d_{6}$.



Figure S57 ${ }^{13} \mathrm{C}$ NMR of 7 in DMSO- $d_{6}$. 


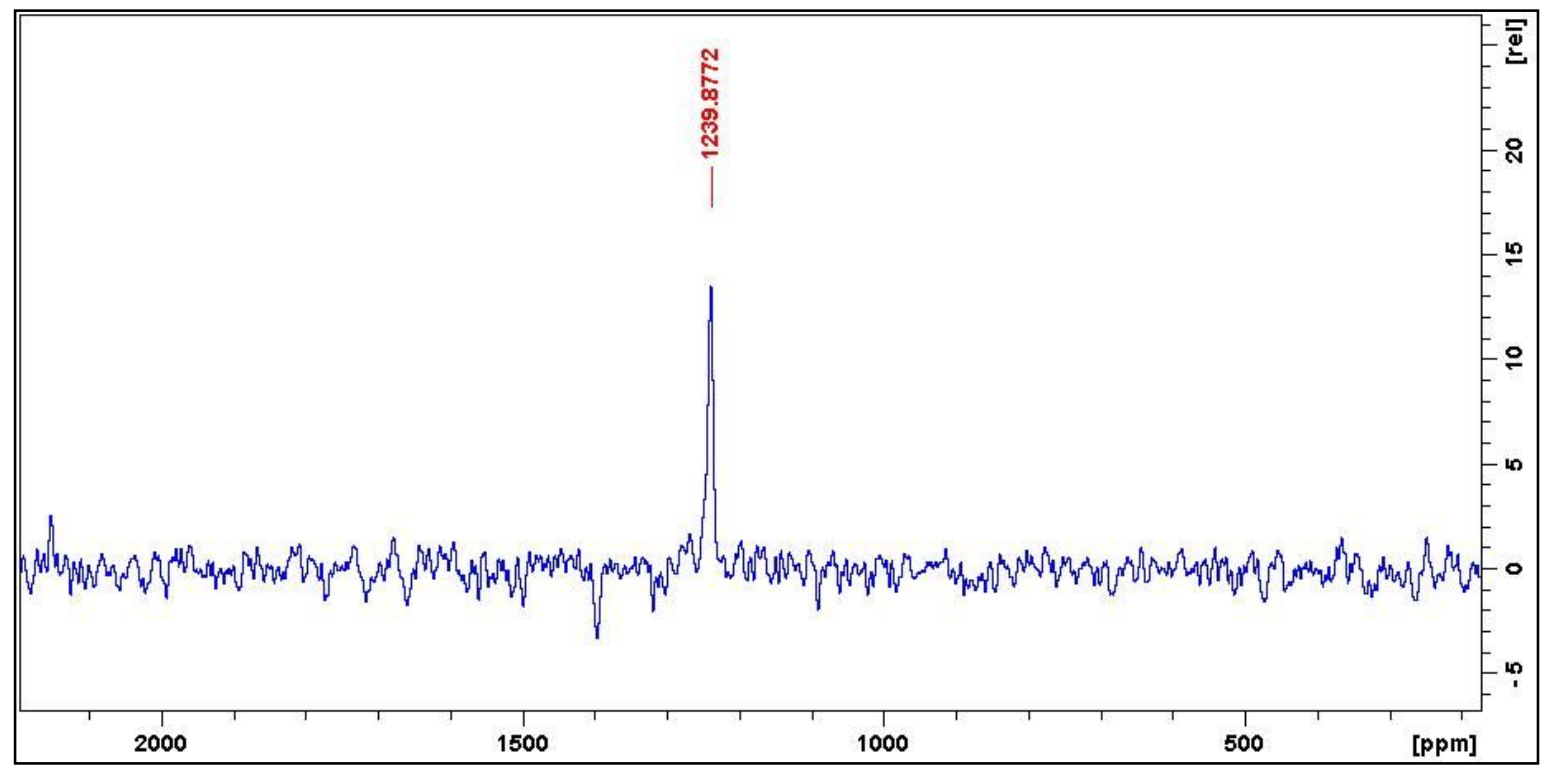

Figure S58 ${ }^{195} \mathrm{Pt}$ NMR of 7 in DMSO- $d_{6}$.

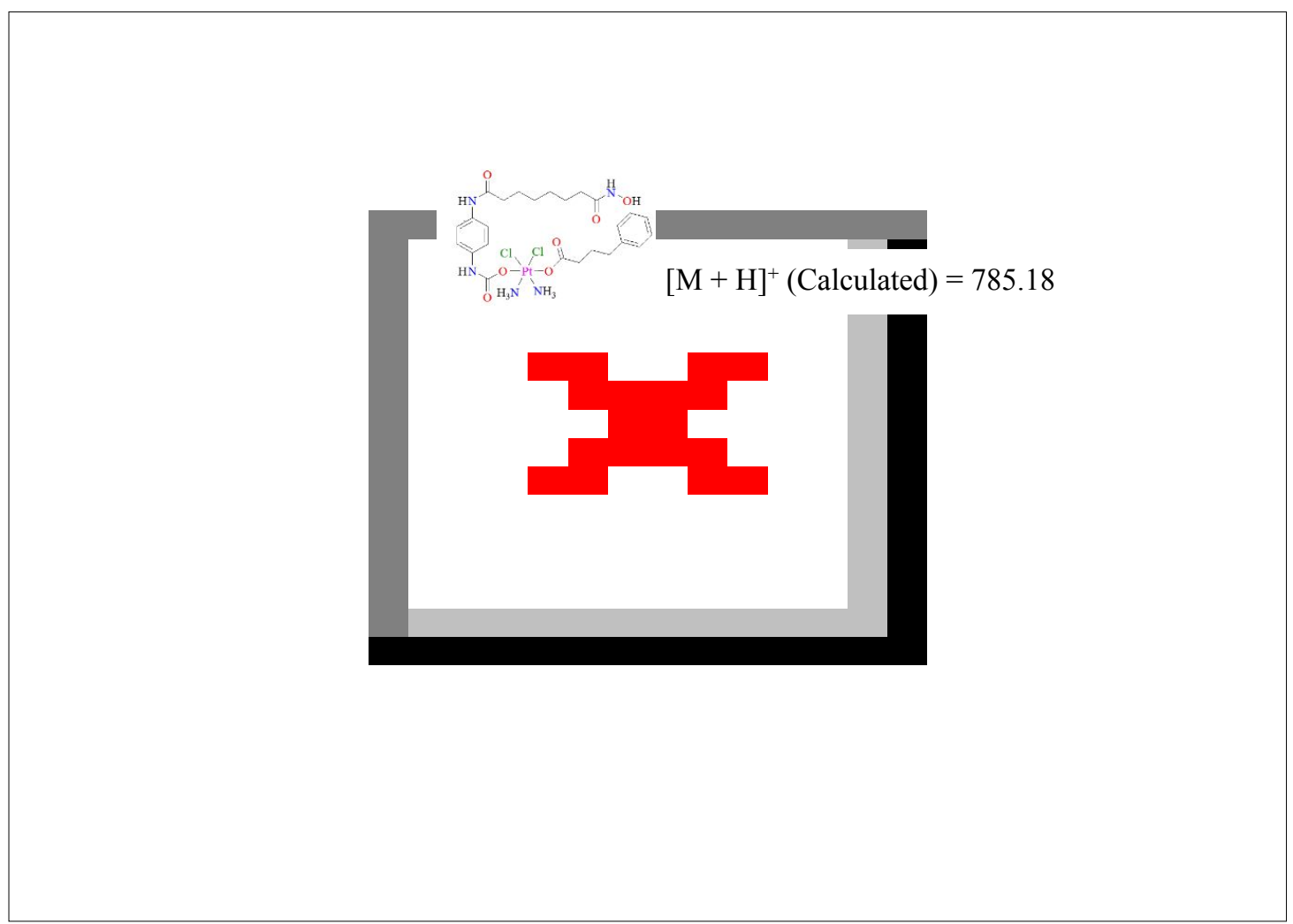

Figure S59 ESI-MS (+ve) data of 7 


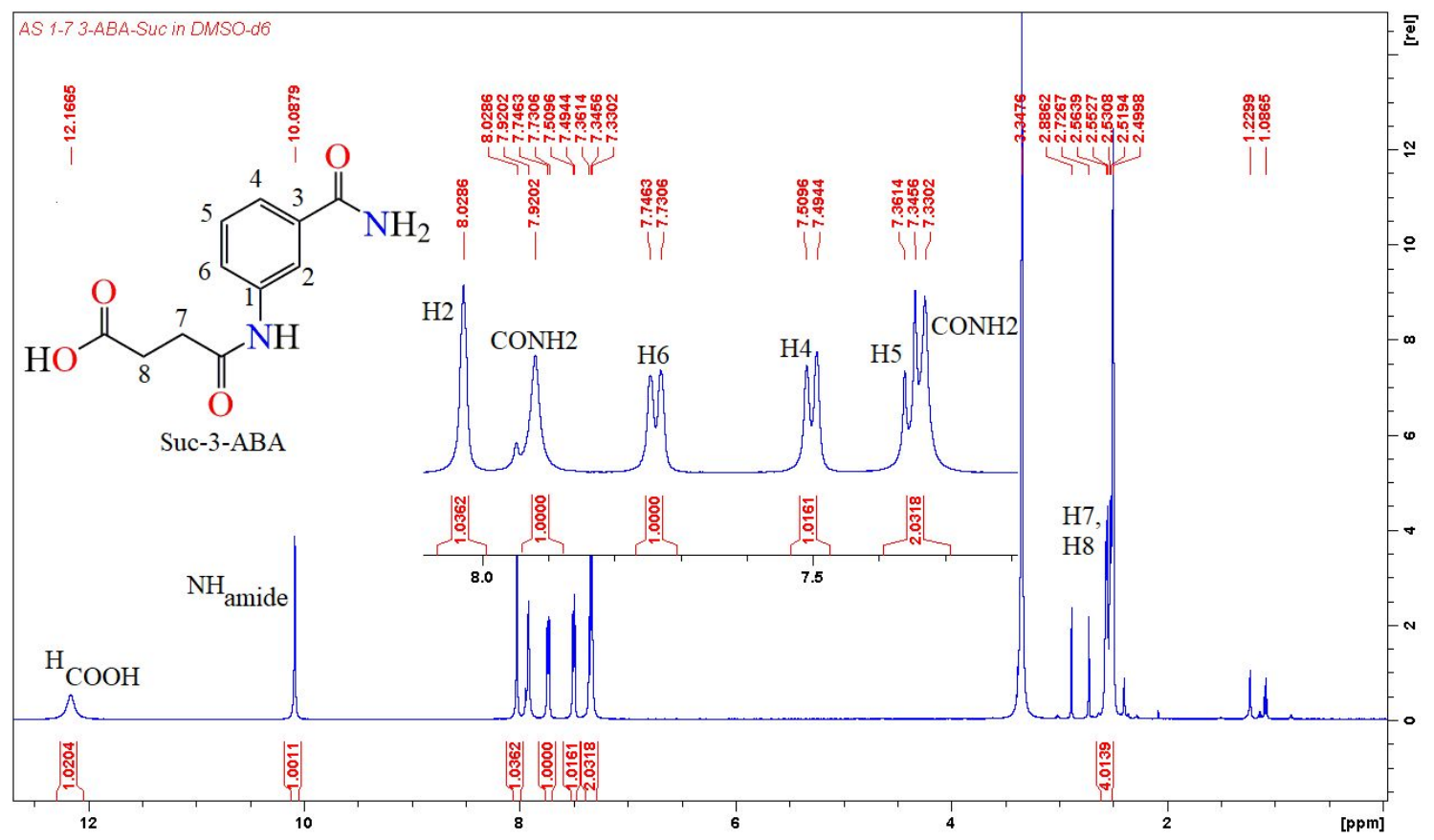

Figure S60 ${ }^{1} \mathrm{H}$ NMR of Suc-3-ABA in DMSO- $d_{6}$.

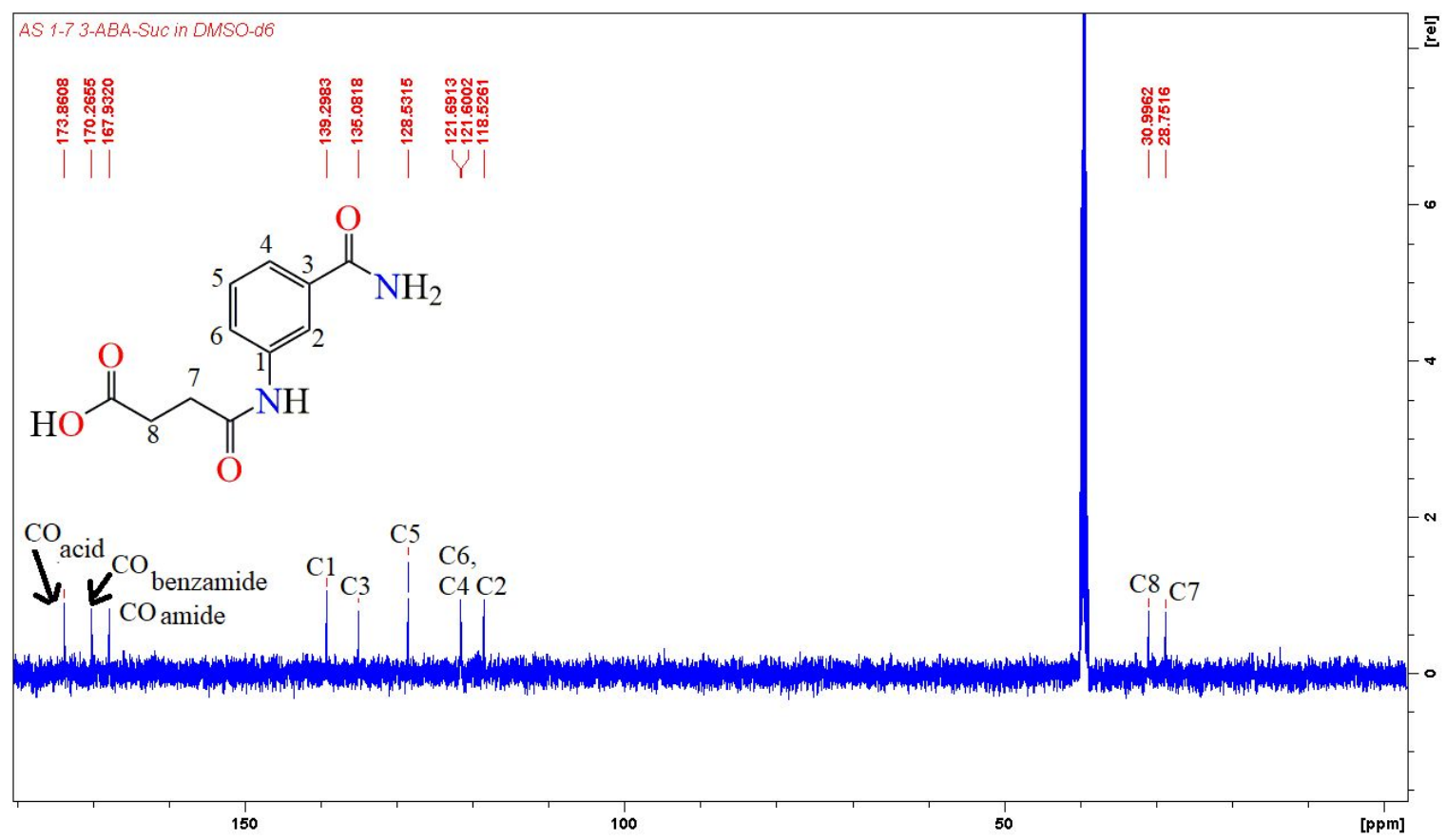

Figure S61 ${ }^{13} \mathrm{C}$ NMR of Suc-3-ABA in DMSO- $d_{6}$. 




\begin{tabular}{||r|ccrrrrr||}
\hline No. & $\begin{array}{c}\text { Ret.Time } \\
\text { min }\end{array}$ & Peak Name & $\begin{array}{c}\text { Height } \\
\text { mAU }\end{array}$ & $\begin{array}{c}\text { Area } \\
\text { mAU*min }\end{array}$ & $\begin{array}{c}\text { Rel.Area } \\
\%\end{array}$ & Amount & Type \\
\hline 1 & 3.09 & n.a. & 2289.237 & 75.034 & 95.08 & n.a. & BMB \\
2 & 6.92 & n.a. & 158.437 & 3.882 & 4.92 & n.a. & BMB $^{*}$ \\
\hline Total: & & & 2447.674 & 78.916 & 100.00 & 0.000 & \\
\hline
\end{tabular}

Figure S62 HPLC chromatogram of 11 ran in $0-100 \%$ linear gradient of water to acetonitrile as mobile phase over $5.84 \mathrm{~min}$ then $2 \mathrm{~min}$ constant at $100 \%$ acetonitrile.

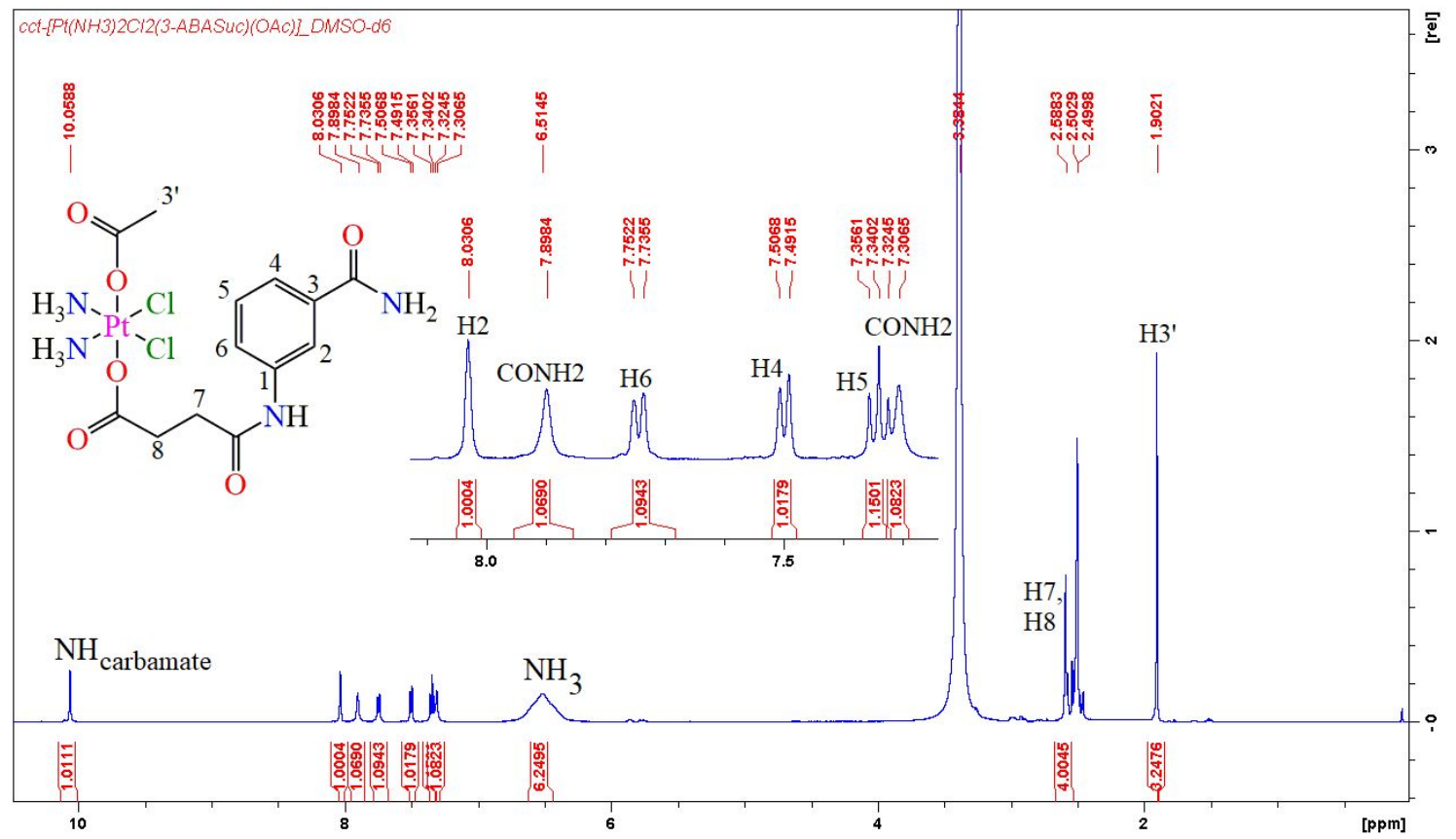

Figure S63 ${ }^{1} \mathrm{H}$ NMR of 11 in DMSO- $d_{6}$. 


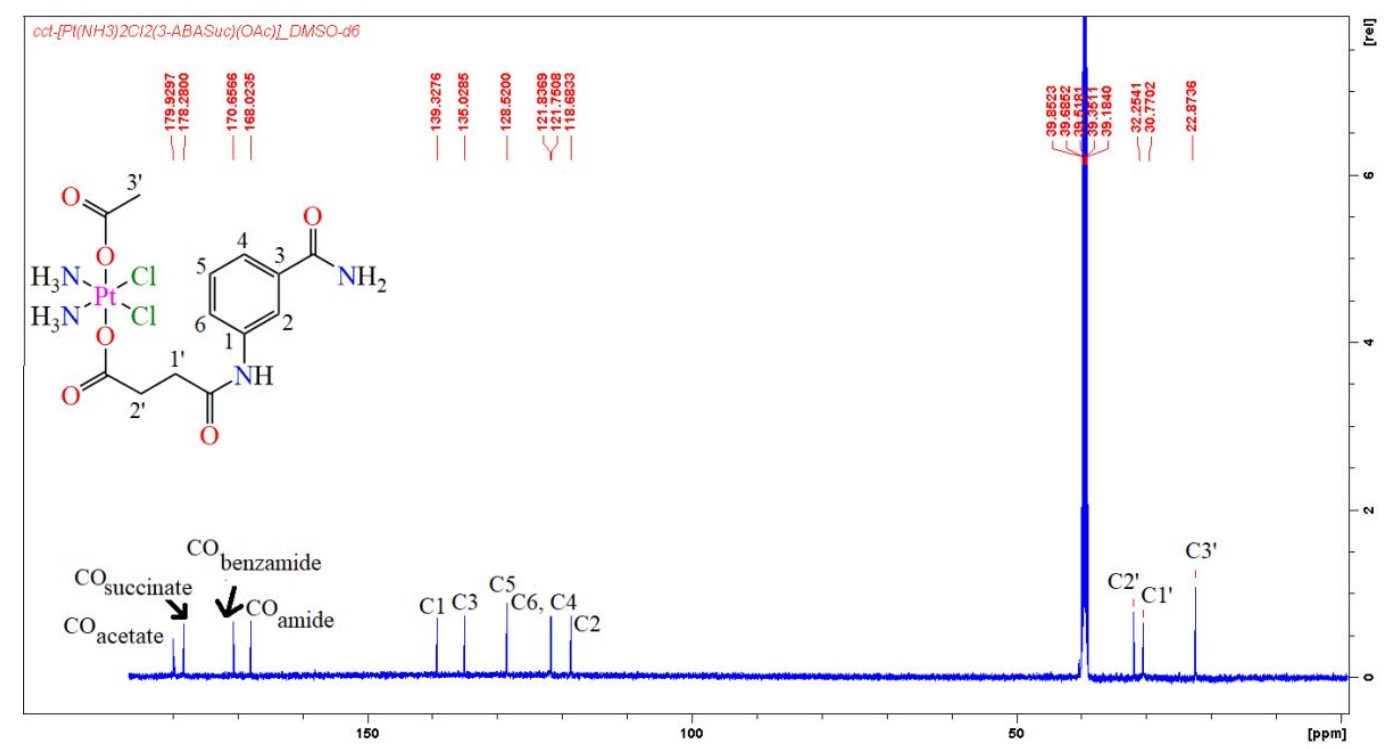

Figure S64 ${ }^{1} \mathrm{H}$ NMR of 11 in DMSO- $d_{6}$.

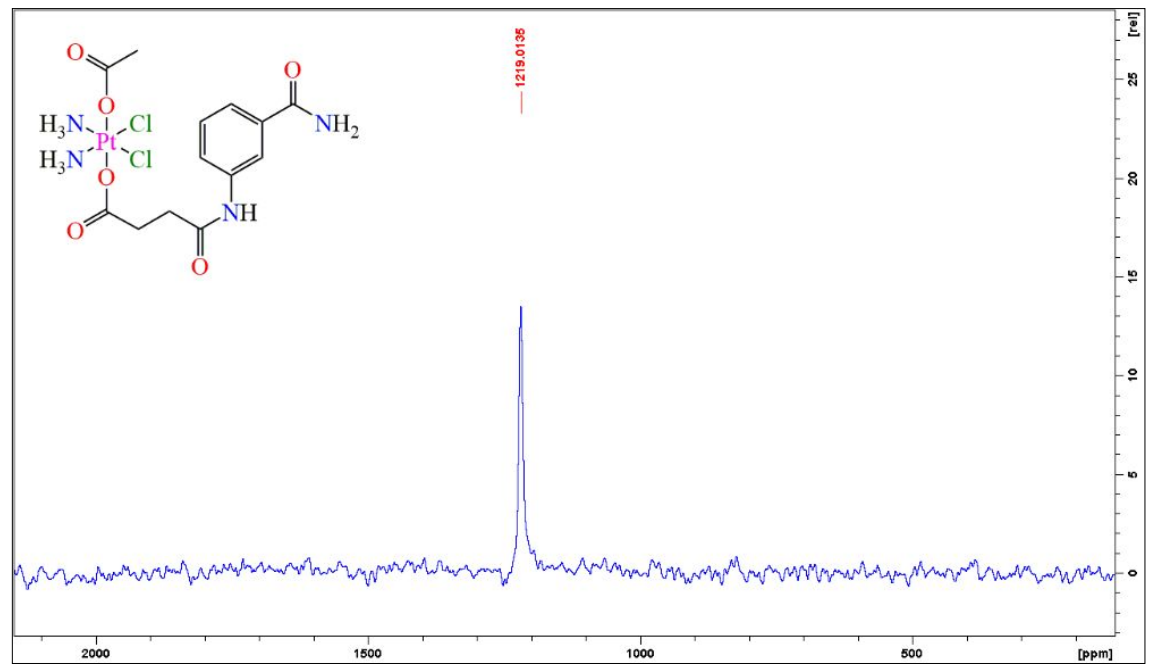

Figure S65 ${ }^{195} \mathrm{Pt}$ NMR of 11 in DMSO- $d_{6}$.

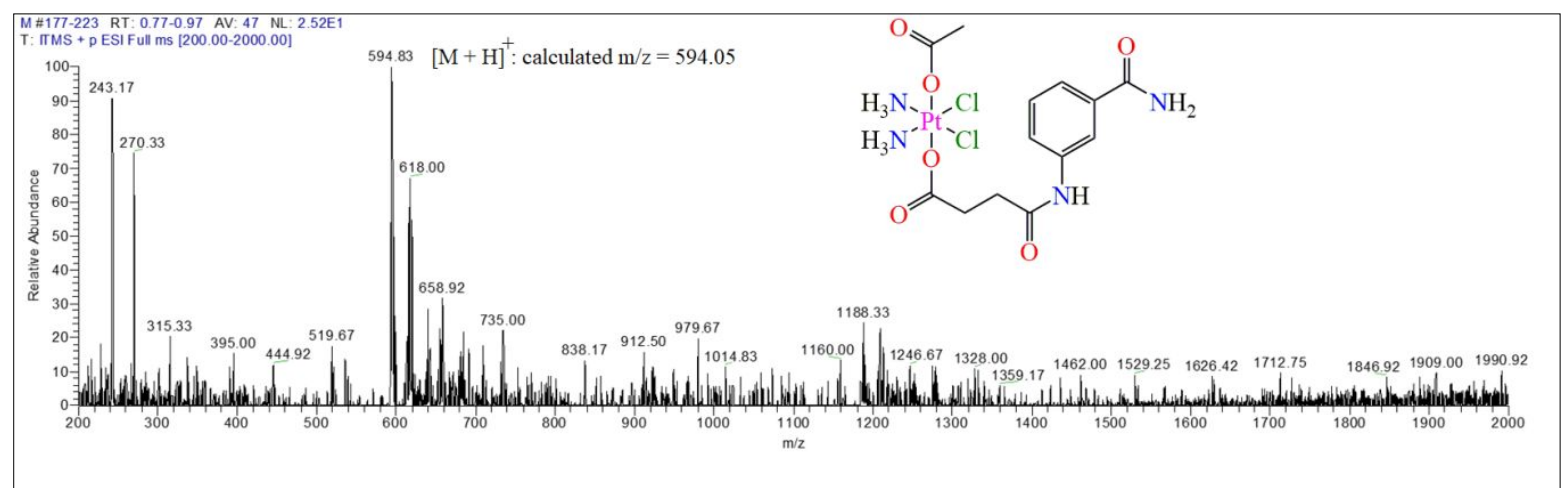

Figure S66 ESI-MS (+ve) data of 11. 


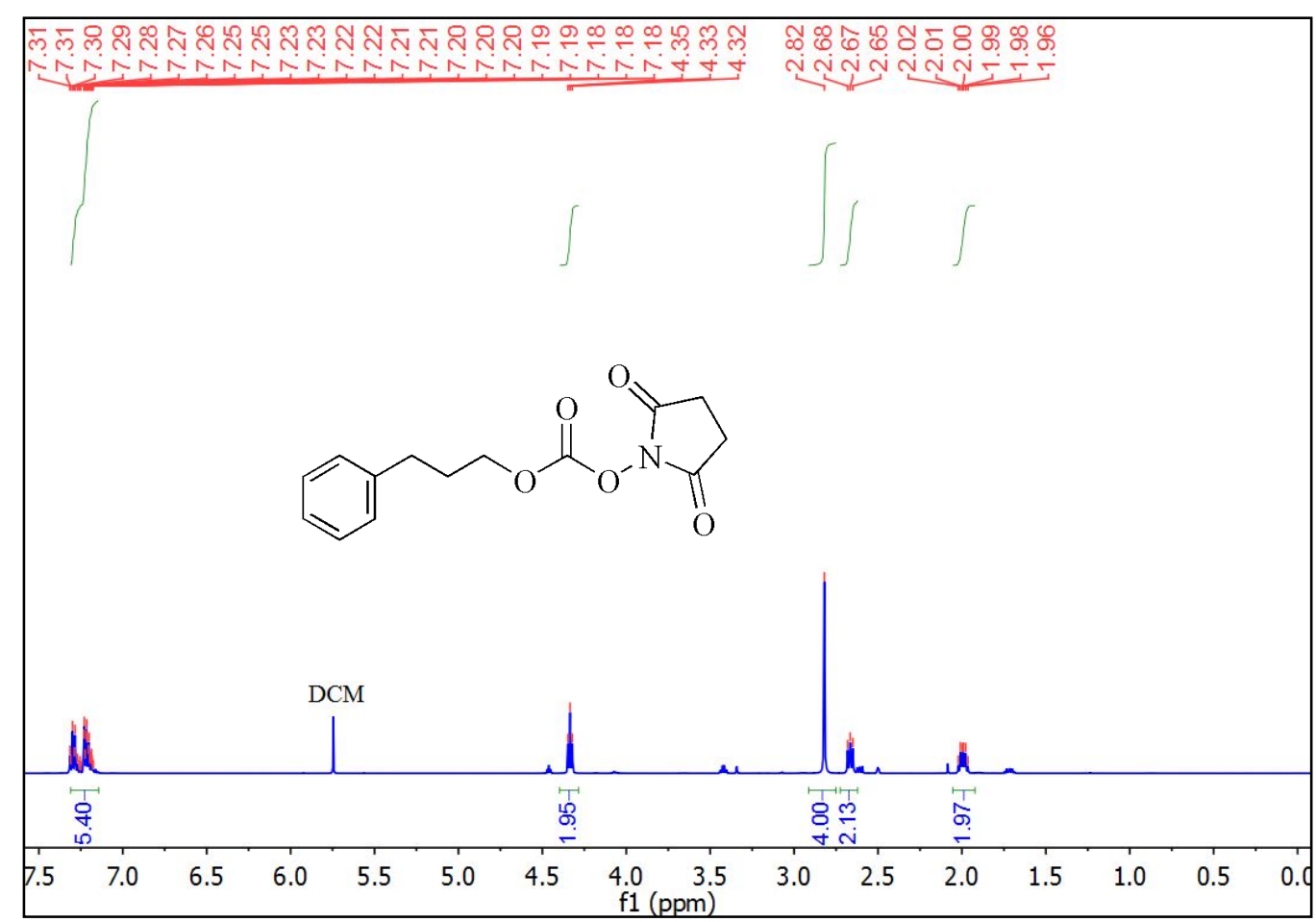

Figure S67 ${ }^{1} \mathrm{H}$ NMR of NHS ester of 3-phenylpropyl-1-carbonate in DMSO- $d_{6}$.

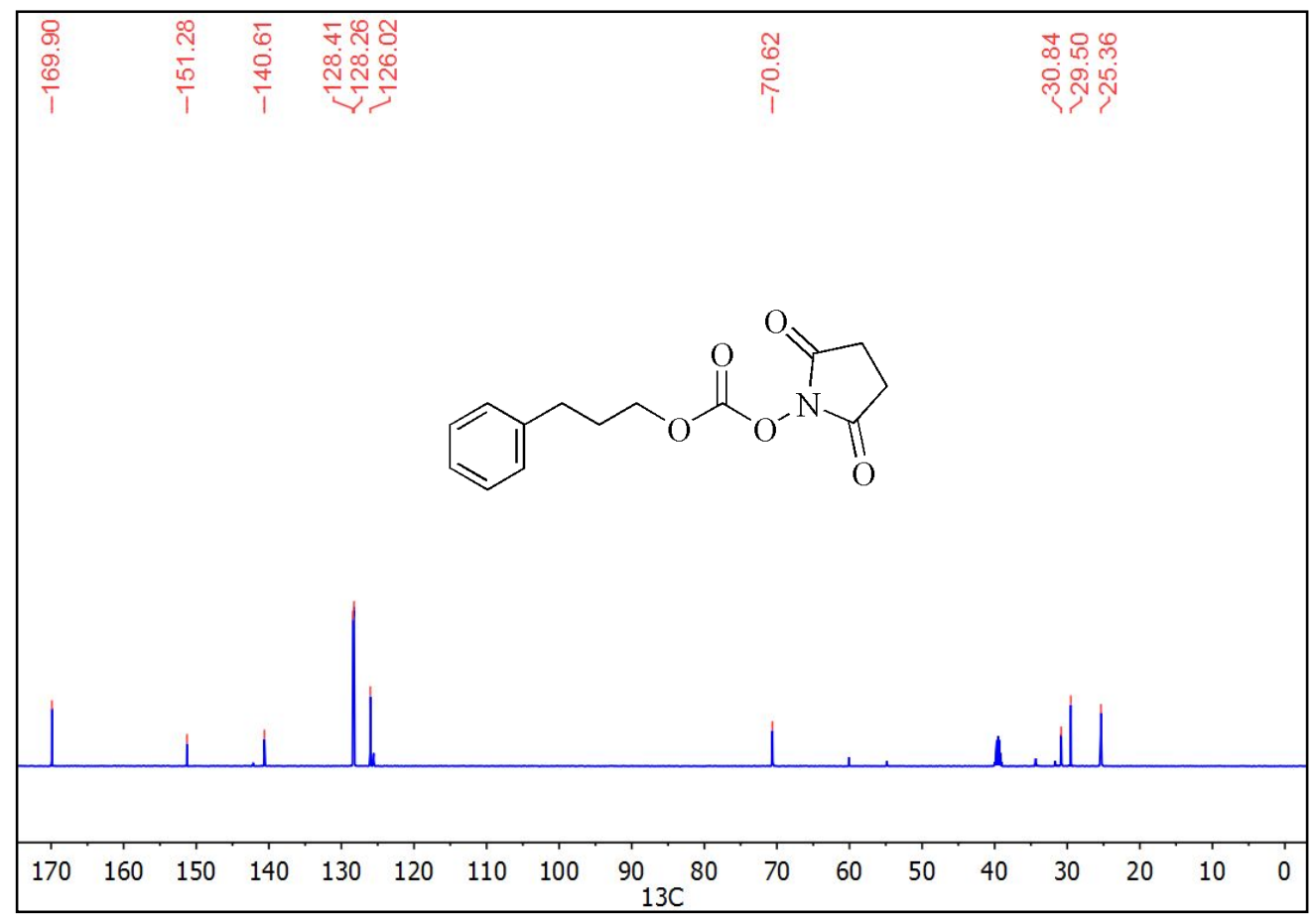

Figure S68 ${ }^{13} \mathrm{C}$ NMR of NHS ester of 3-phenylpropyl-1-carbonate in DMSO- $d_{6}$. 


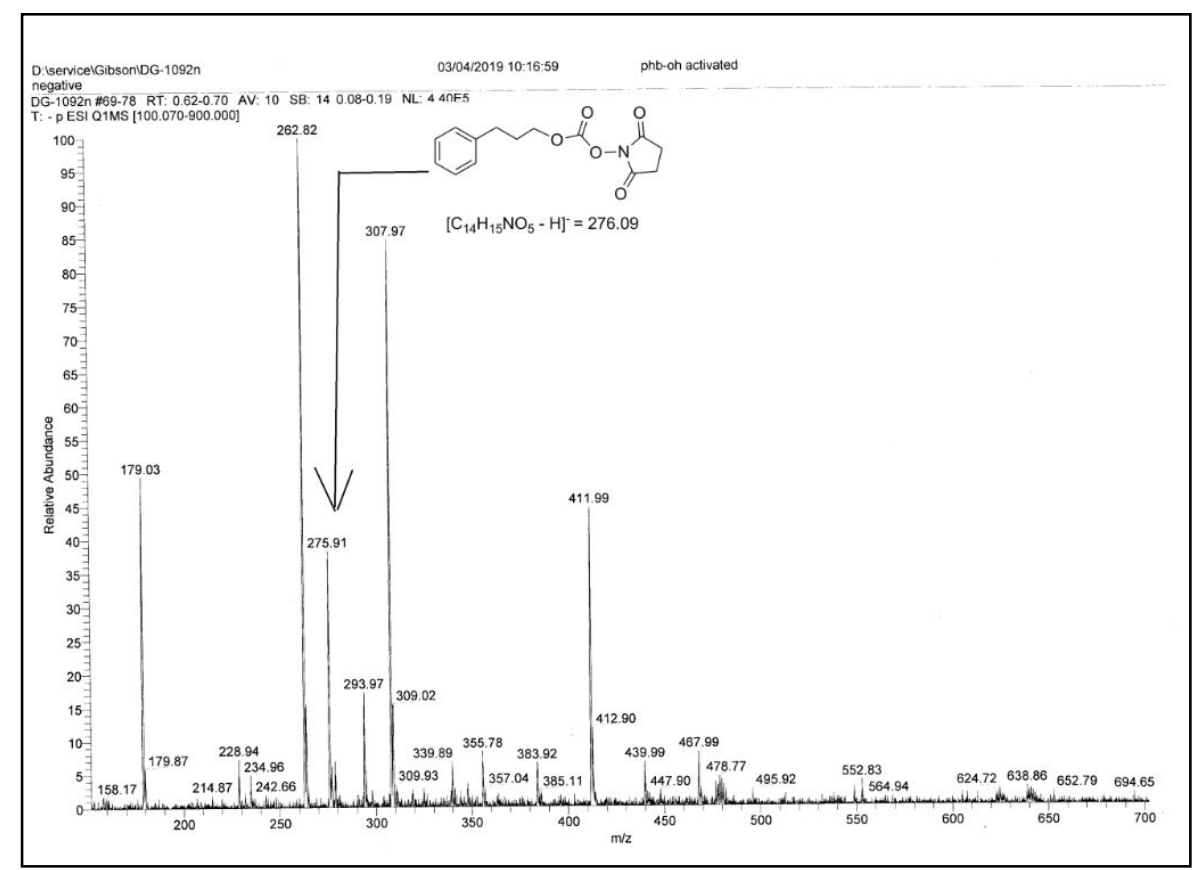

Figure S69 ESI-MS (-ve) of NHS ester of 3-phenylpropyl-1-carbonate.

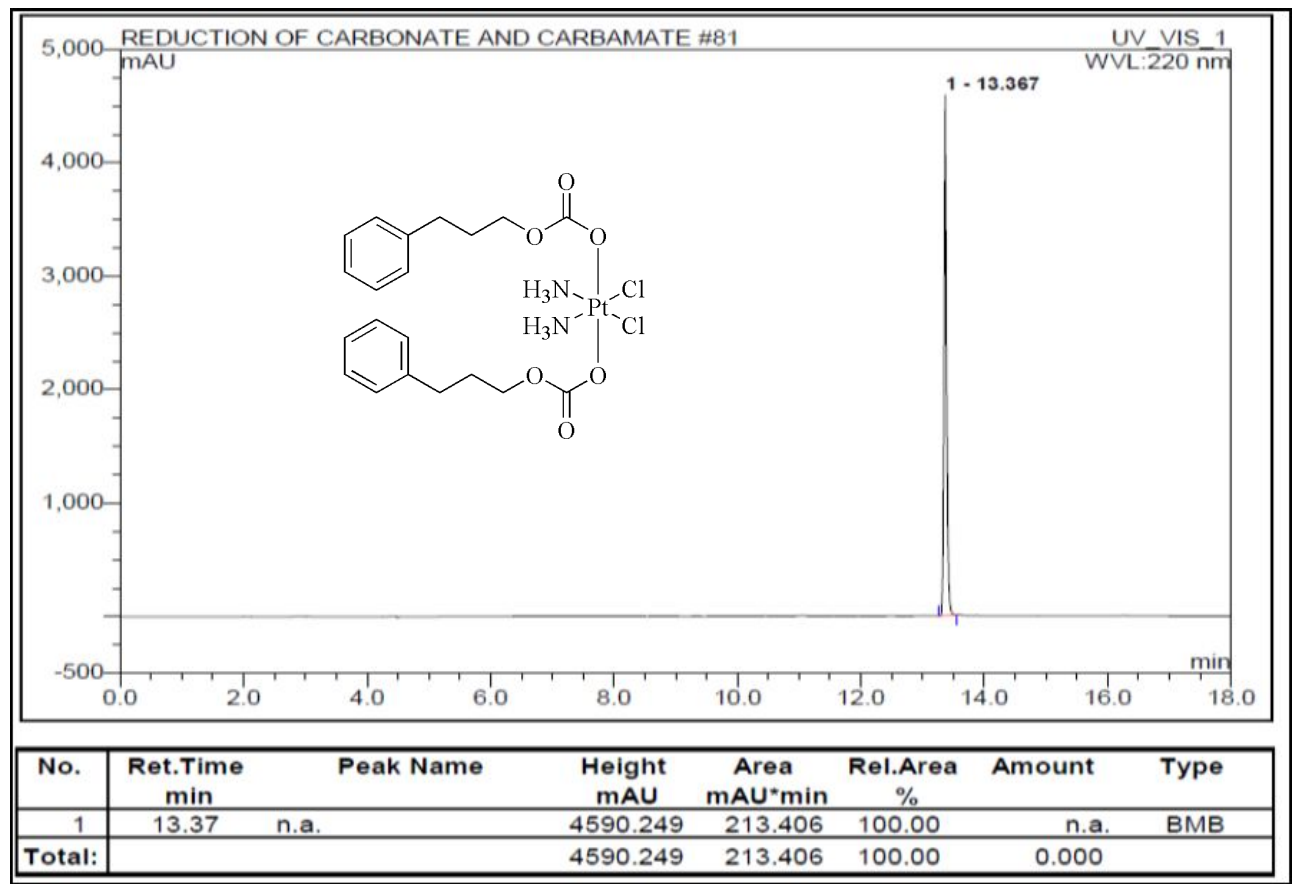

Figure S70 HPLC chromatogram of 9 ran with $0-100 \%$ acetonitrile in $15 \mathrm{~min}$ then 3 min constant at $100 \%$ acetonitrile. 


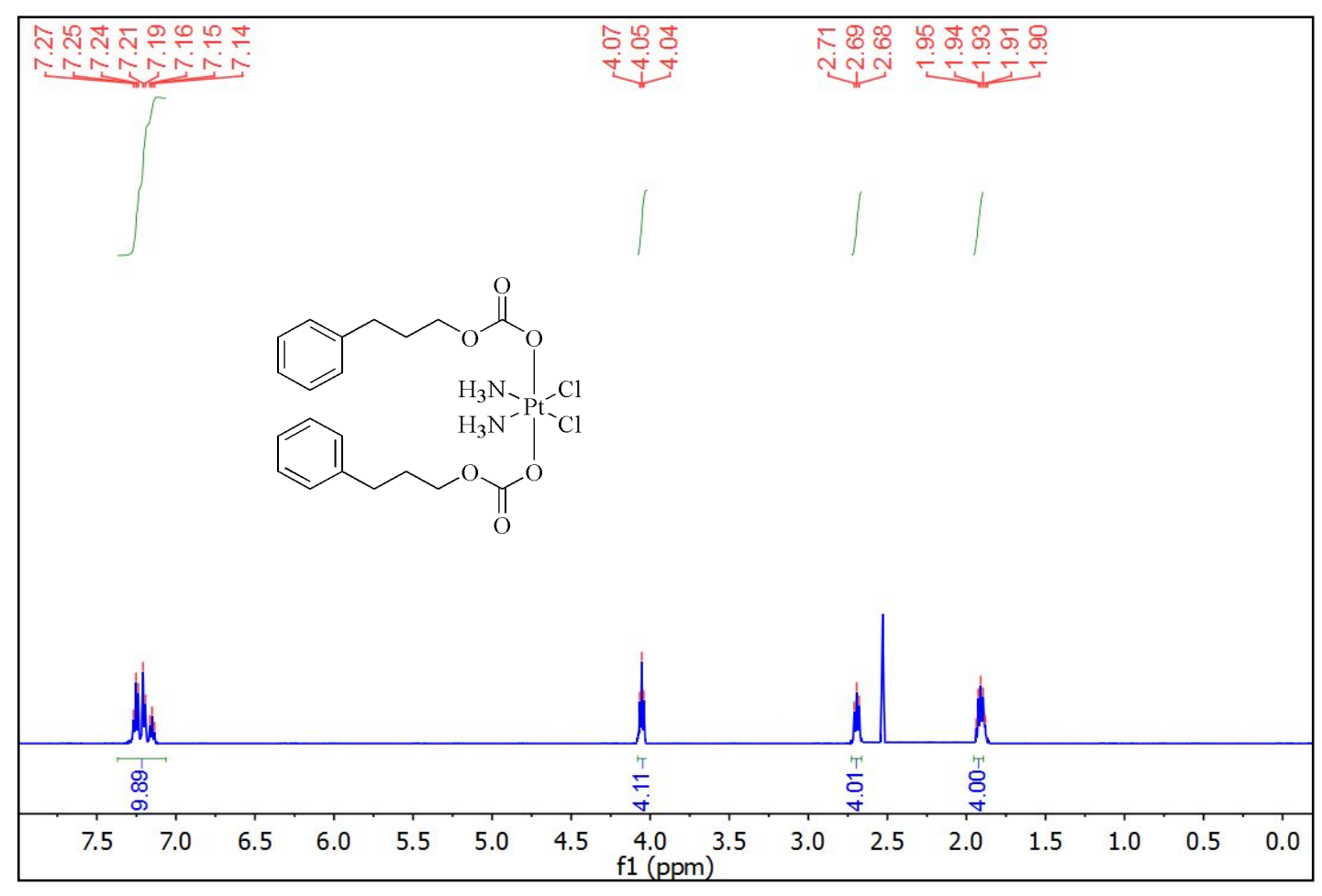

Figure S71 ${ }^{1} \mathrm{H}$ NMR of 9 in DMSO- $d_{6}$.



Figure $\mathbf{S 7 2}{ }^{13} \mathrm{C}$ NMR of 9 in DMSO- $d_{6}$. 


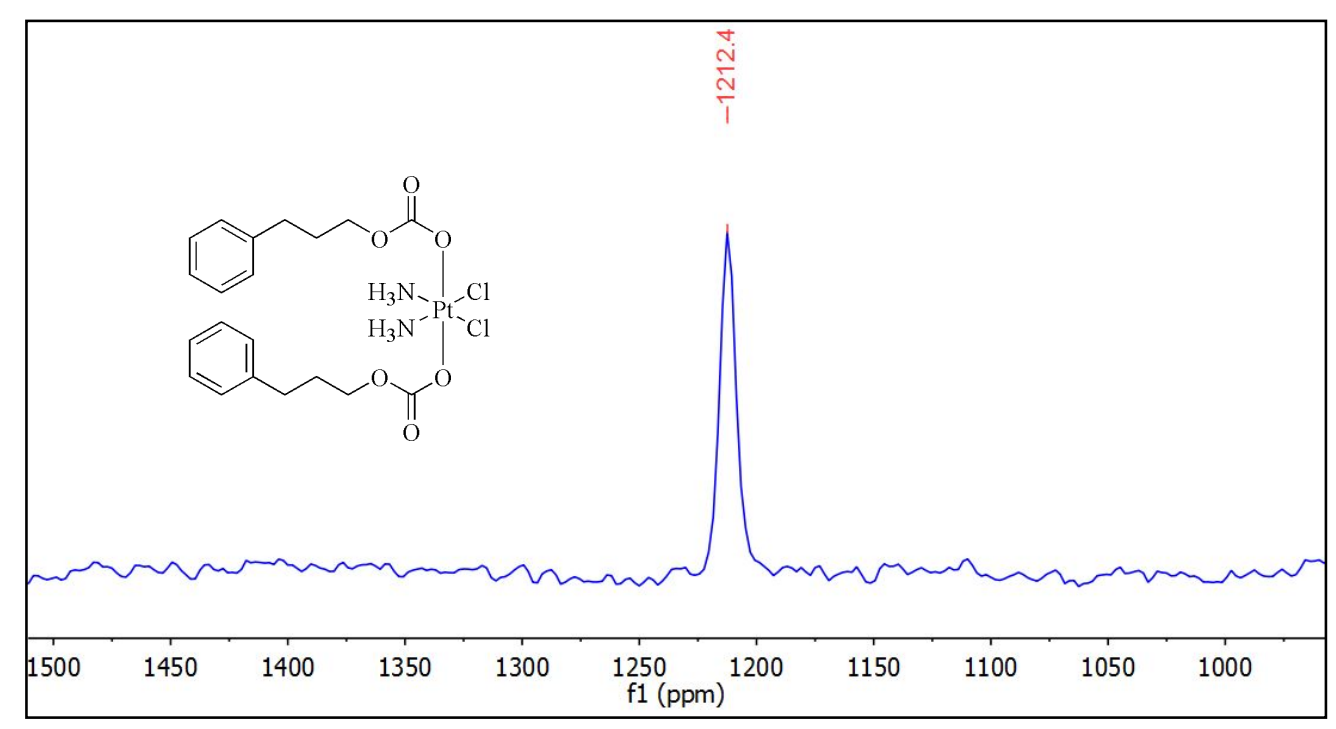

Figure S73 ${ }^{195} \mathrm{Pt}$ NMR of 9 in DMSO- $d_{6}$.

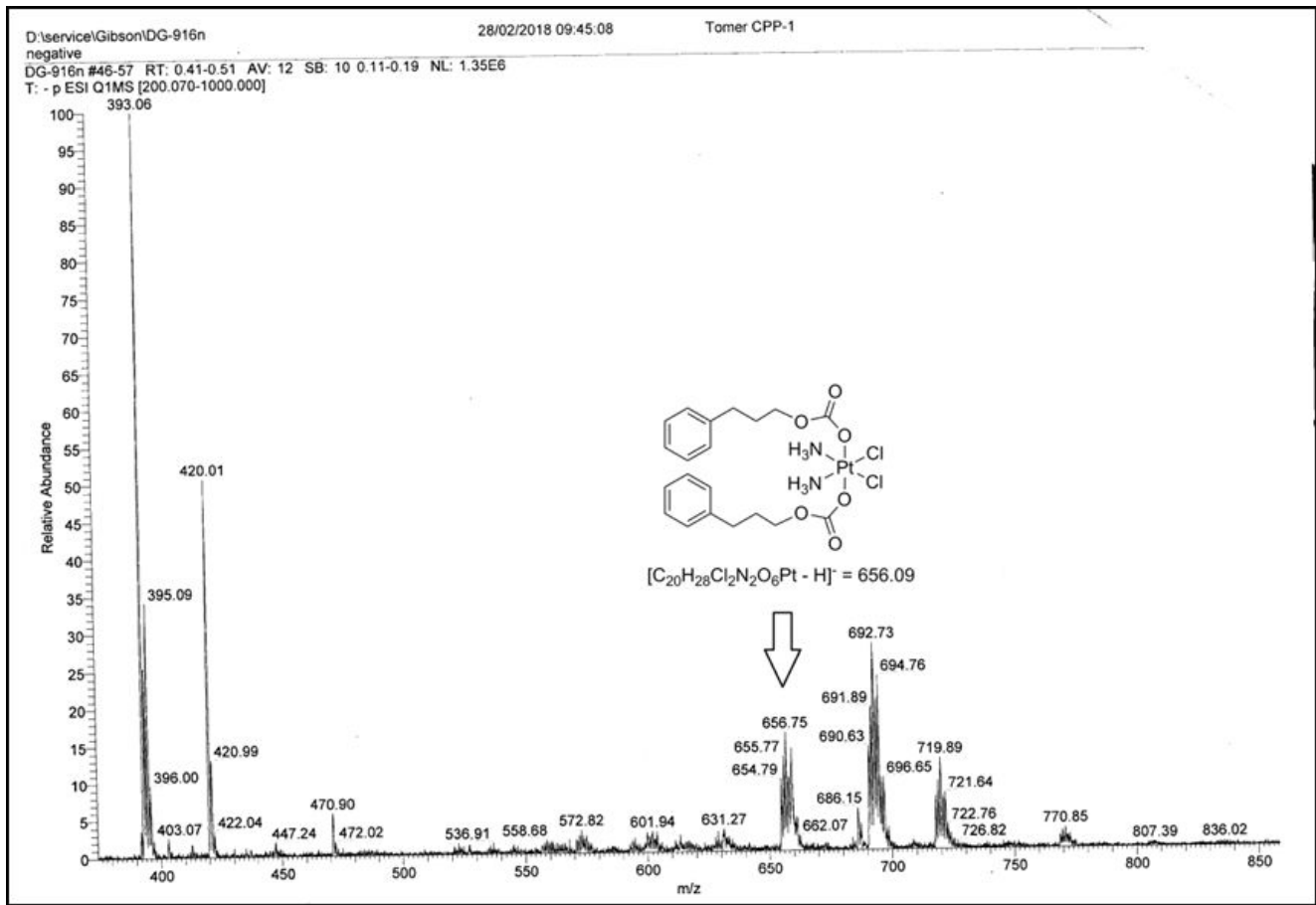

Figure S74 ESI-MS (-ve) data of 9. 


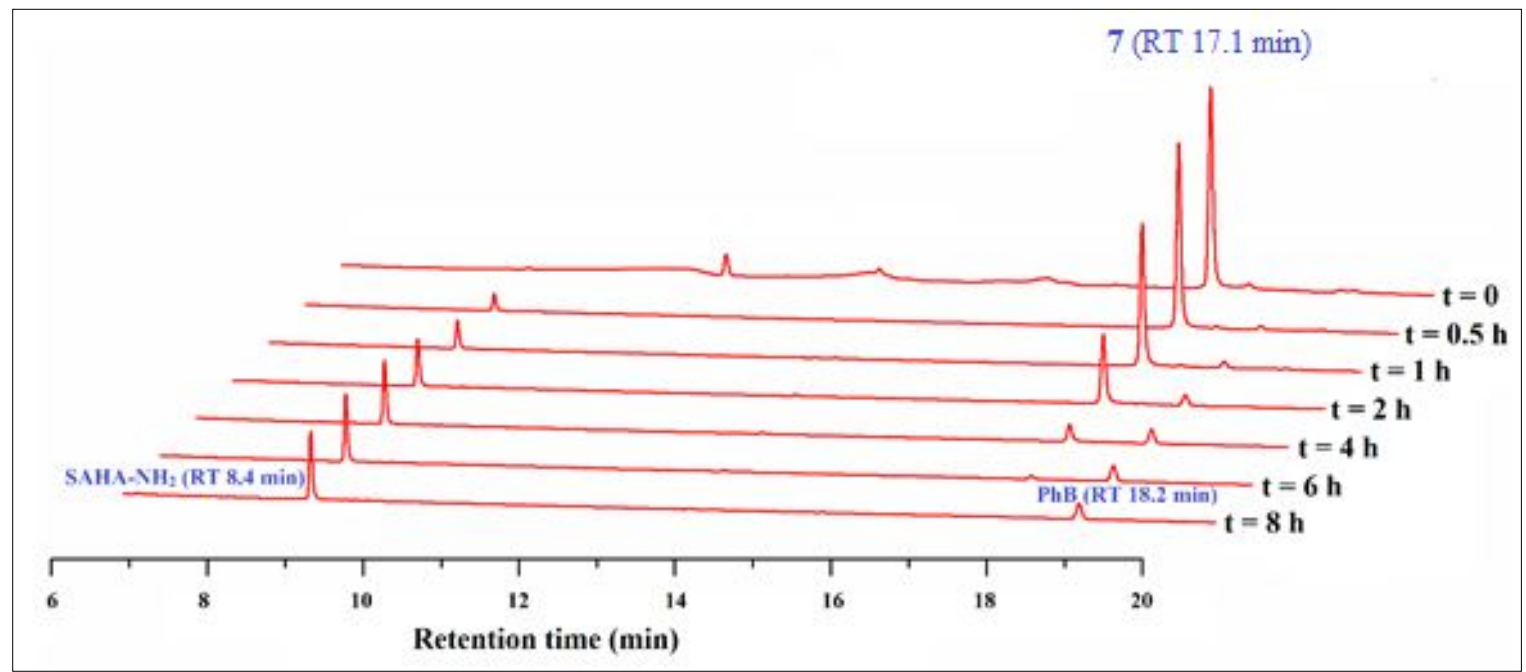

Figure S75 HPLC chromatogram of 7 in presence of 10 equivalents of ascorbic acid taken at different time interval in a 1:1 mixture of methanol \& $100 \mathrm{mM}$ phosphate buffer of $\mathrm{pH}$ 7.0 at $37^{\circ} \mathrm{C}$.

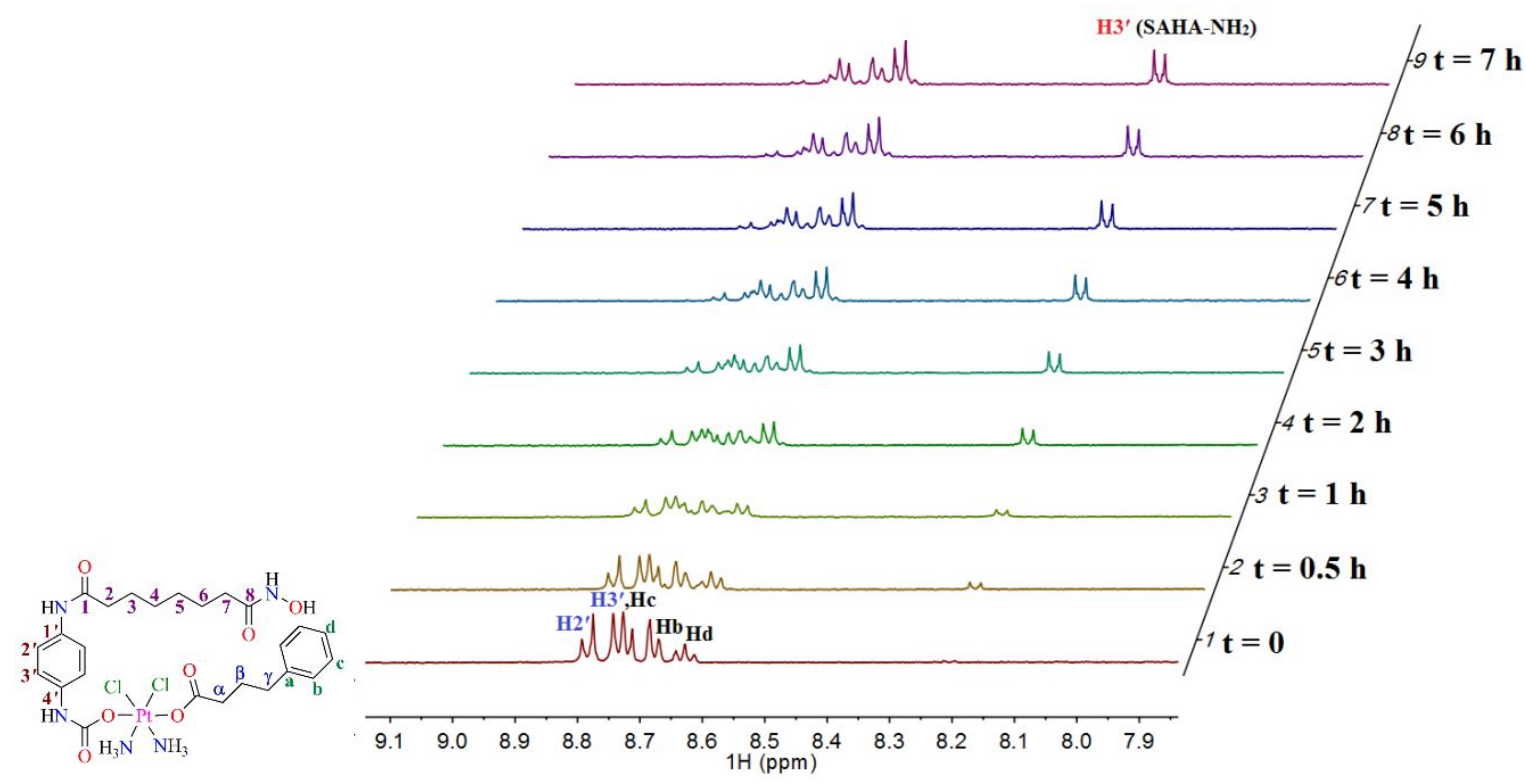

Figure S76 Stack plot of NMR kinetic data of 7 in presence of 10 equivalents of ascorbic acid in a 1:1 mixture of MeOD- $d_{4} \& 100 \mathrm{mM}$ phosphate buffer of $\mathrm{pH} 7.0$ (prepared in $\mathrm{D}_{2} \mathrm{O}$ ) at $37^{\circ} \mathrm{C}$. The data shows the distinct upfield shift of $\mathrm{H}^{\prime}$ of $\mathrm{Pt}^{\mathrm{IV}}$ complex (blue) forming free $\mathrm{SAHA}-\mathrm{NH}_{2}$ ligand (red) upon reduction followed by decarboxylation. 

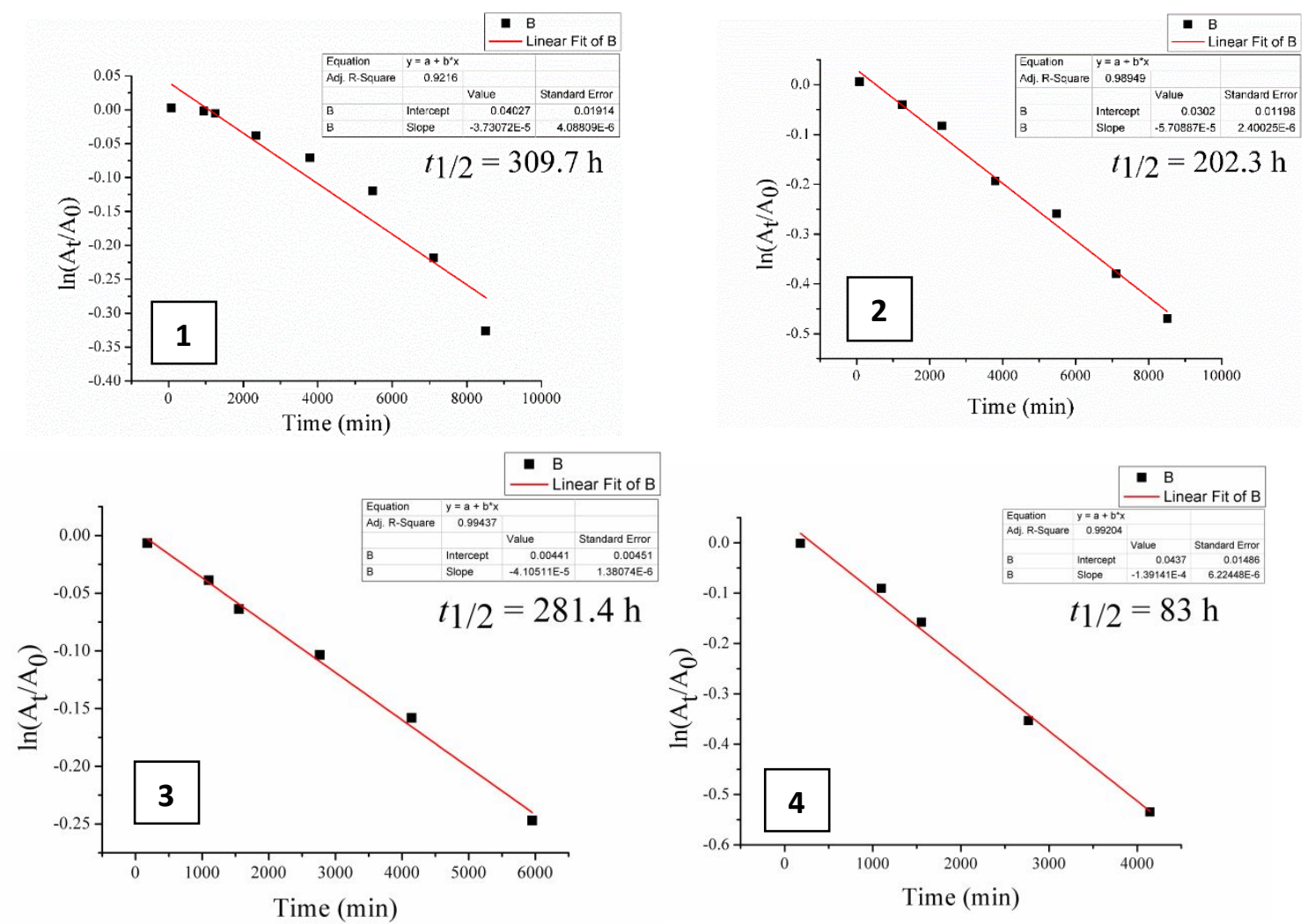

Figure S77 Half-lives $\left(t_{1 / 2}\right)$ of compounds $\mathbf{1}-\mathbf{4}$ in cell culture medium.
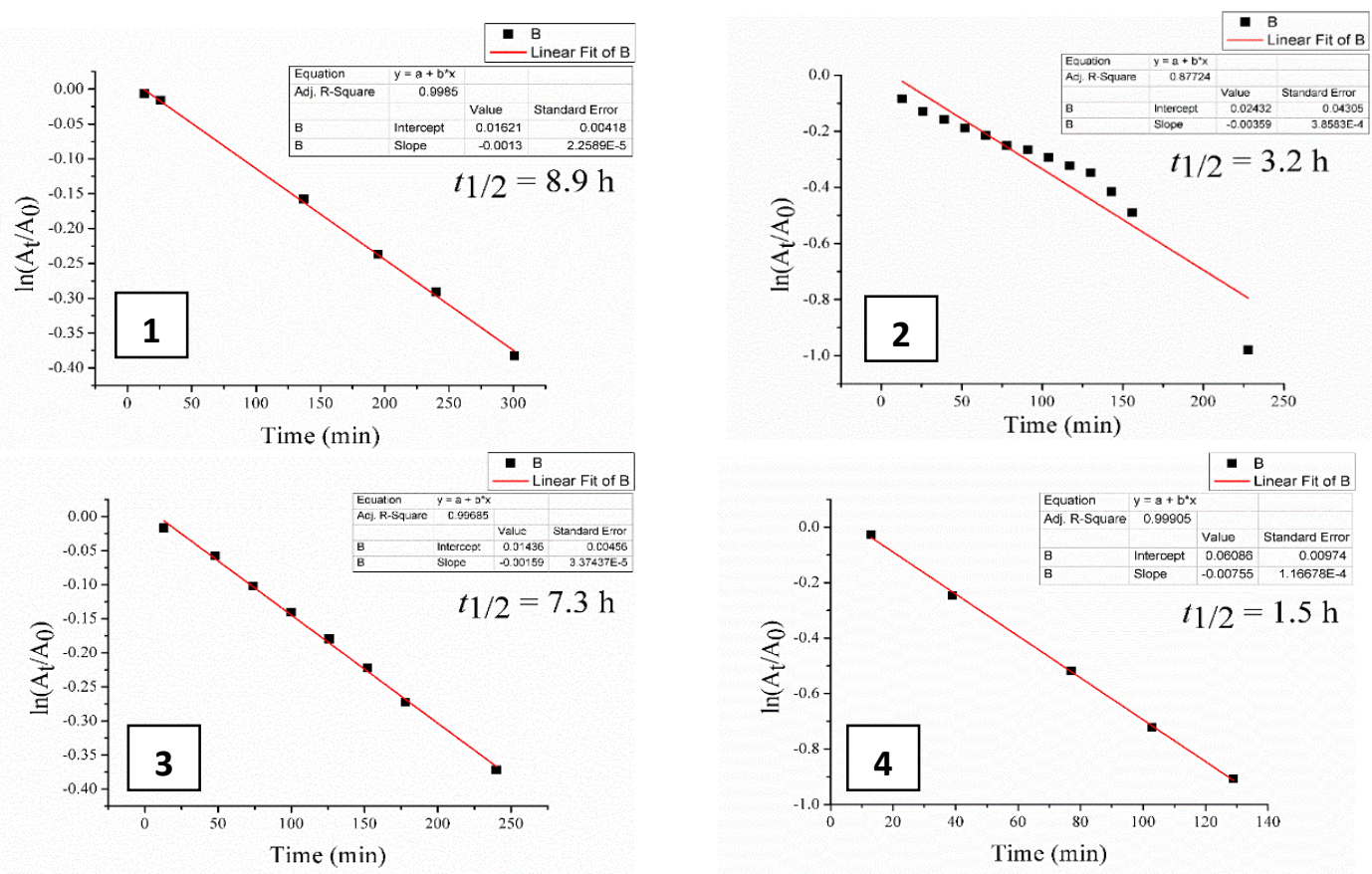

Figure S78 Half-lives $\left(t_{1 / 2}\right)$ of compounds $\mathbf{1}-\mathbf{4}$ in presence of 10 equivalents of ascorbic acid. 


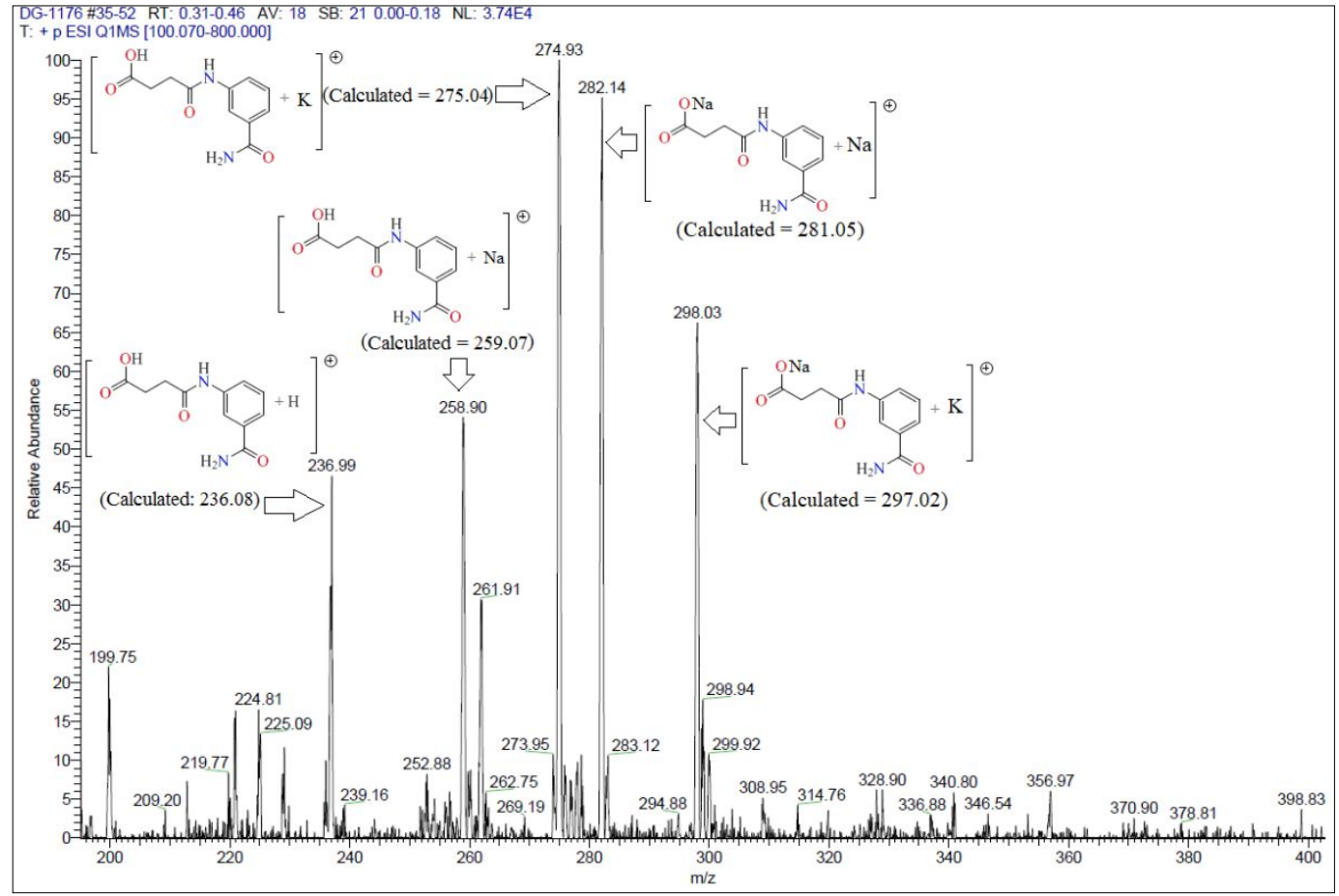

Figure S79 ESI-MS (+ve) speciations of the solution containing 11 and 10 eqv ascorbic acid in $100 \mathrm{mM}$ phosphate buffer of $\mathrm{pH} 7.0$ after 2 days at $37^{\circ} \mathrm{C}$. This data is showing the species mostly from intact succinated 3-ABA.

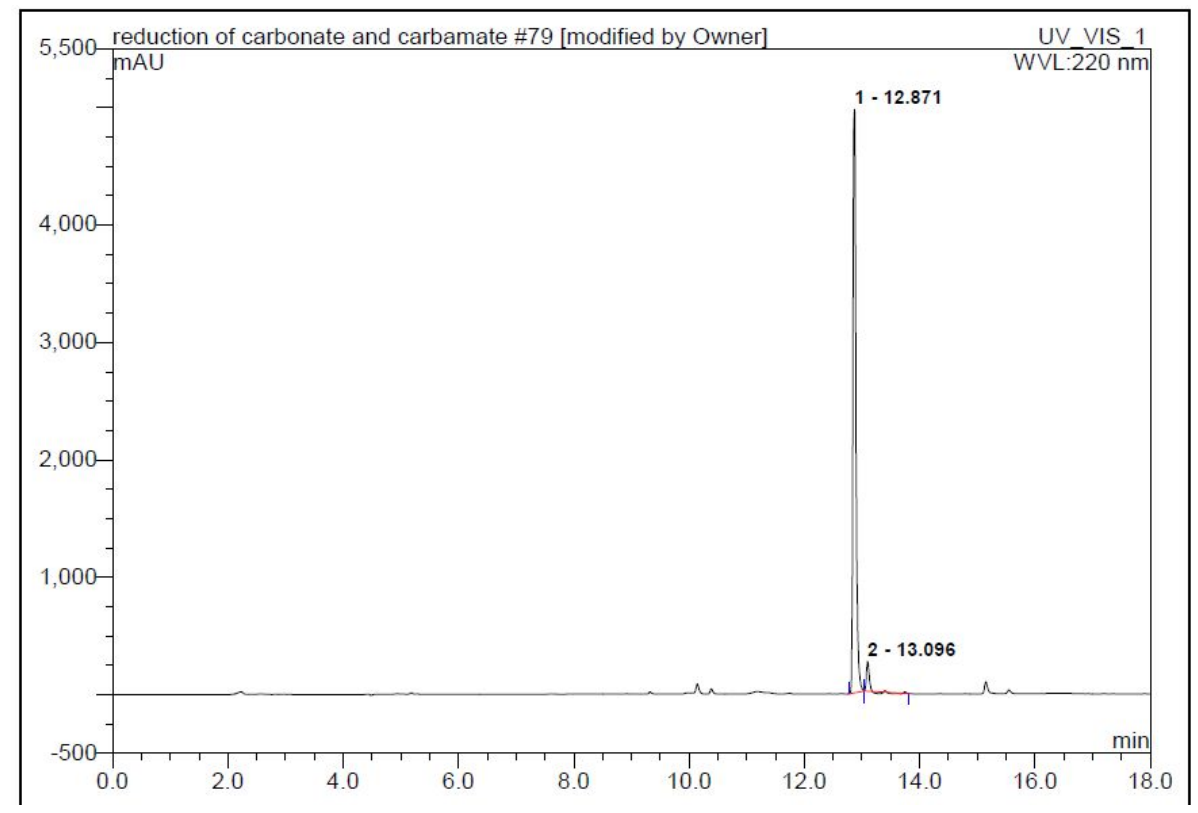

Figure $\mathbf{S} 80$ The HPLC chromatogram of compound 8 




Figure $\mathbf{8 8 1}$ The HPLC chromatogram of compound $\mathbf{9}$

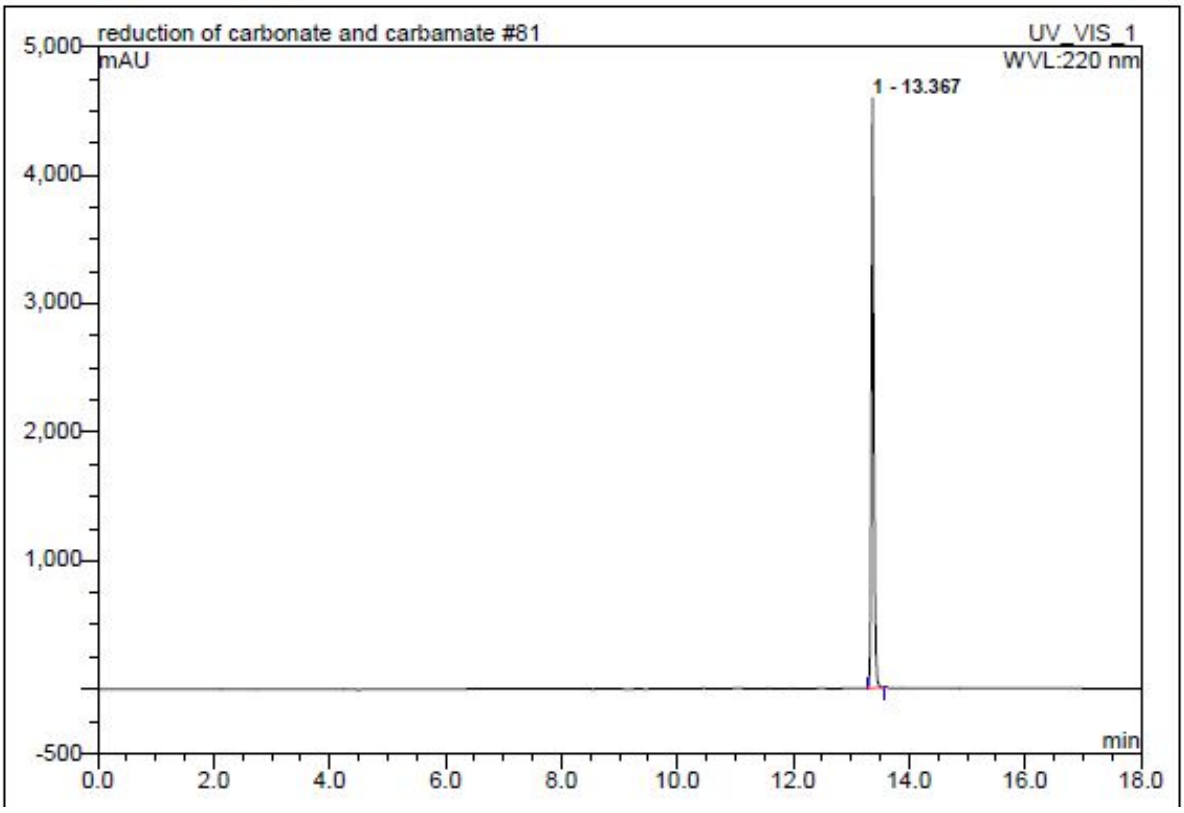

Figure S82 The HPLC chromatogram of compound $\mathbf{1 0}$ 